\section{ENUIBONMENTAL MANAGEMENT \& ENRICHMENT FACIIITIES}

\title{
ALARA Plan for the Old Hydrofracture Facility Tanks Contents Removal Project at Oak Ridge National Laboratory, Oak Ridge, Tennessee
}

\author{
RECEIVED \\ APR 249998 \\ OSTI
}

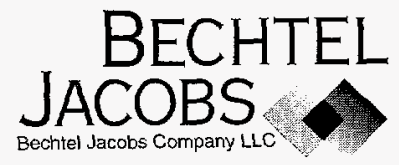




\section{CDM Federal Programs Corporation}

contributed to the preparation of this document and should not be considered an eligible contractor for its review. 


\title{
ALARA Plan for the Old Hydrofracture Facility Tanks Contents Removal Project at Oak Ridge National Laboratory, Oak Ridge, Tennessee
}

Date Issued-April 1998

\author{
Prepared by \\ CDM Federal Programs Corporation \\ Oak Ridge, Tennessee \\ under subcontract 96B-99052C \\ Document Control No. 5151-005-FR-BBYN
}

Prepared for the

U.S. Department of Energy

Office of Environmental Management

Environmental Management Activities at OAK RIDGE NATIONAL LABORATORY

Oak Ridge, Tennessee 37831 managed by

BECHTEL JACOBS COMPANY LLC for the

U.S. DEPARTMENT OF ENERGY under contract DE-AC05-98OR22700 


\section{DISCLAIMER}

Portions of this document may be illegible electronic image products. Images are produced from the best available original document. 
ORNL/ER-429

APPROVAL PAGE

ALARA Plan for the Old Hydrofracture Facility Tanks Contents Removal Project at Oak Ridge National Laboratory, Oak Ridge, Tennessee
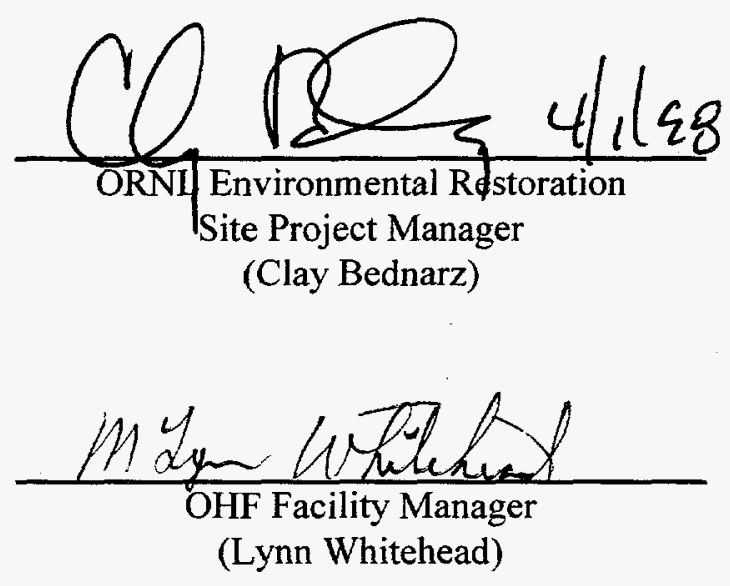

land 73016

ALARA Engineering Group Representative (Rich Utrera)

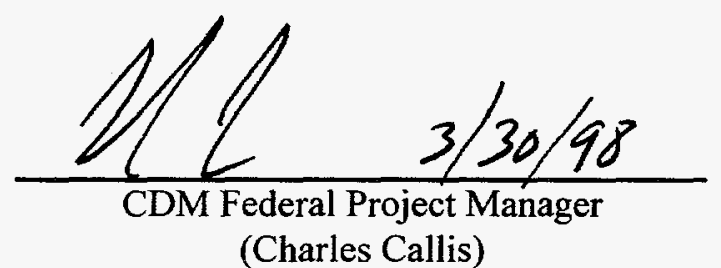

No Clem francis $4 / 1 / 98$ Radiation Surveillance Section Complex Leader (Jo Ellen Francis)

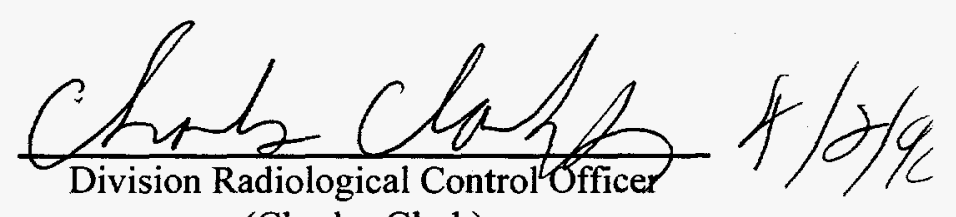
(Charles Clark) 


\title{
CONTENTS
}

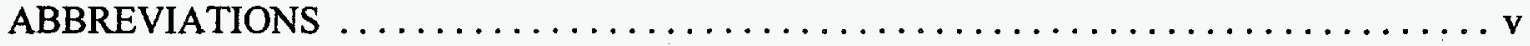

EXECUTIVE SUMMARY $\ldots \ldots \ldots \ldots \ldots \ldots \ldots \ldots \ldots \ldots \ldots \ldots \ldots \ldots$ vii

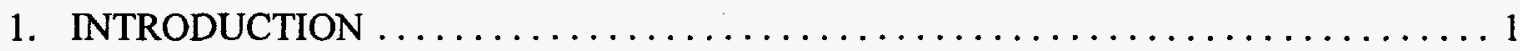

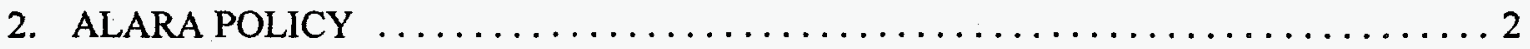

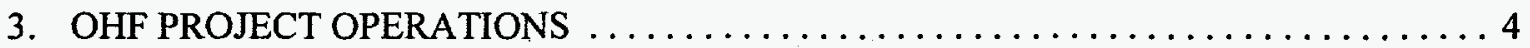

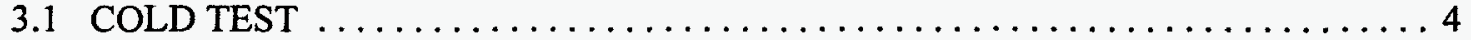

3.2 EQUIPMENT INSTALLATION AND MOBILIZATION $\ldots \ldots \ldots \ldots \ldots \ldots \ldots \ldots$

3.3 SLUICING AND PUMPING OPERATIONS $\ldots \ldots \ldots \ldots \ldots \ldots \ldots \ldots \ldots \ldots 5$

3.4 OPERATIONS MAINTENANCE AND REPAIR ACTIVITIES $\ldots \ldots \ldots \ldots \ldots \ldots 6$

3.5 DEACTIVATION AND DEMOBILIZATION $\ldots \ldots \ldots \ldots \ldots \ldots \ldots \ldots \ldots \ldots$

4. FUNCTIONAL ROLES AND RESPONSIBILITIES $\ldots \ldots \ldots \ldots \ldots \ldots \ldots \ldots \ldots \ldots 7$

4.1 ALARA ENGINEERING GROUP REPRESENTATIVE $\ldots \ldots \ldots \ldots \ldots \ldots \ldots \ldots 7$

4.2 RADIOLOGICAL CONTROL TECHNICIAN $\ldots \ldots \ldots \ldots \ldots \ldots \ldots \ldots \ldots \ldots 7$

4.3 SITE SAFETY AND HEALTH OFFICER $\ldots \ldots \ldots \ldots \ldots \ldots \ldots \ldots \ldots \ldots$

4.4 FIELD OPERATIONS SUPERINTENDENT $\ldots \ldots \ldots \ldots \ldots \ldots \ldots \ldots \ldots \ldots \ldots$

4.5 WORKERS PERFORMING RADIOLOGICAL WORK $\ldots \ldots \ldots \ldots \ldots \ldots \ldots$

4.6 CDM FEDERAL PROJECT MANAGER $\ldots \ldots \ldots \ldots \ldots \ldots \ldots \ldots \ldots \ldots \ldots \ldots \ldots \ldots$

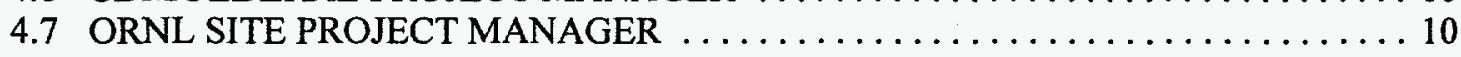

5. CONDUCT OF OPERATIONS AND GOOD PRACTICES $\ldots \ldots \ldots \ldots \ldots \ldots \ldots \ldots 11$

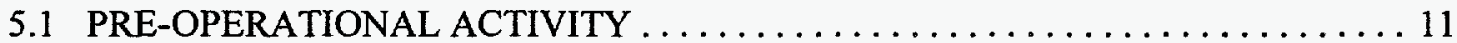

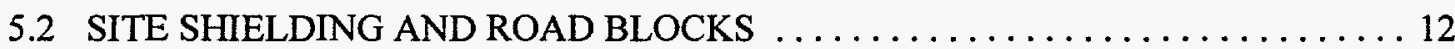

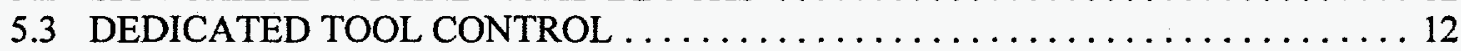

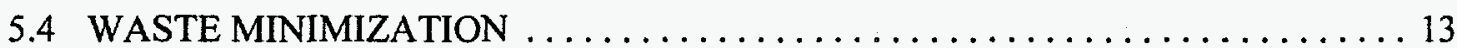

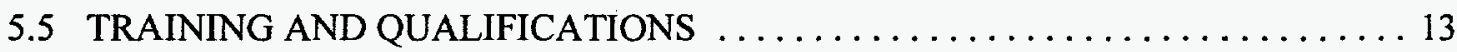

5.6 NUCLEAR CRITICALITY SAFETY APPROVAL REQUIREMENTS $\ldots \ldots \ldots 13$

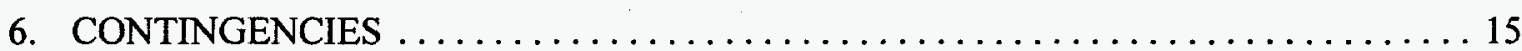

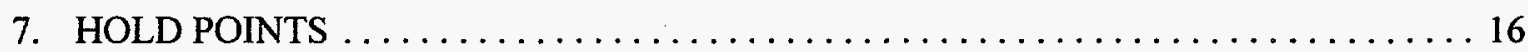

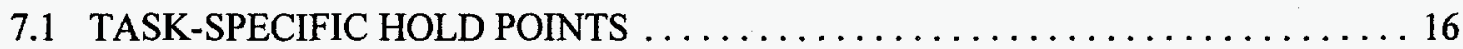

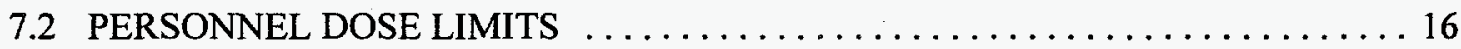

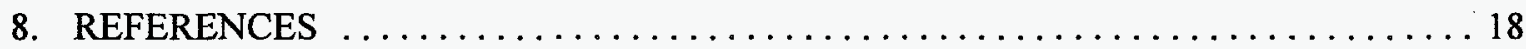

APPENDIX A: ALARA REVIEW - RISER SPOOL AND SUBMERSIBLE

PUMP INSTALLATION TASK (REVISION 1.0) $\ldots \ldots \ldots \ldots \ldots \ldots \ldots \ldots$ A-1

APPENDIX B: ALARA PLANNING FOR TASKS ASSOCIATED WITH

EQUIPMENT INSTALLATION AND MOBILIZATION AND

SLUICING AND PUMPING OPERATIONS $\ldots \ldots \ldots \ldots \ldots \ldots \ldots \ldots \ldots . . \ldots \ldots$

APPENDIX C: DAILY ALARA PRE-JOB BRIEFING TOPICS $\ldots \ldots \ldots \ldots \ldots \ldots \ldots \ldots$ C-1

APPENDIX D: ALARA OPERATIONS REVIEW CHECKLIST $\ldots \ldots \ldots \ldots \ldots \ldots \ldots$ D- 1 


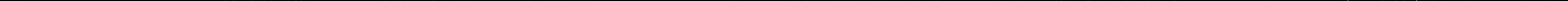




\section{ABBREVIATIONS}

$\begin{array}{ll}\text { ALARA } & \text { as low as reasonably achievable } \\ \text { APR } & \text { air-purifying respirator } \\ \text { CAM } & \text { continuous air monitor } \\ \text { CDM Federal } & \text { CDM Federal Programs Corporation } \\ \text { COA } & \text { conditions of approval } \\ \text { Energy Systems } & \text { Lockheed Martin Energy Systems, Inc. } \\ \text { ES\&H } & \text { environment, safety, and health } \\ \text { ETE } & \text { ETE Consulting Engineering, Inc. } \\ \text { HASP } & \text { health and safety plan } \\ \text { LLLW } & \text { liquid low-level waste } \\ \text { LSS } & \text { Laboratory Shift Superintendent } \\ \text { MVST } & \text { Melton Valley Storage Tanks } \\ \text { NCS } & \text { Nuclear Criticality Safety } \\ \text { NCSA } & \text { Nuclear Criticality Safety Approval } \\ \text { OHF } & \text { Old Hydrofracture Facility } \\ \text { ORNL } & \text { Oak Ridge National Laboratory } \\ \text { ORP } & \text { Office of Radiation Protection } \\ \text { PPE } & \text { personal protective equipment } \\ \text { PVC } & \text { polyvinyl chloride } \\ \text { RCT } & \text { radiological control technician } \\ \text { RQ } & \text { reportable quantity } \\ \text { RWP } & \text { radiological work permit } \\ \text { SSHO } & \text { Site Safety and Health Officer } \\ \text { TEDE } & \text { total effective dose equivalent } \\ \text { TLD } & \text { thermoluminescent dosimeter } \\ \text { TTCTF } & \text { Tanks Technology Cold Test Facility }\end{array}$




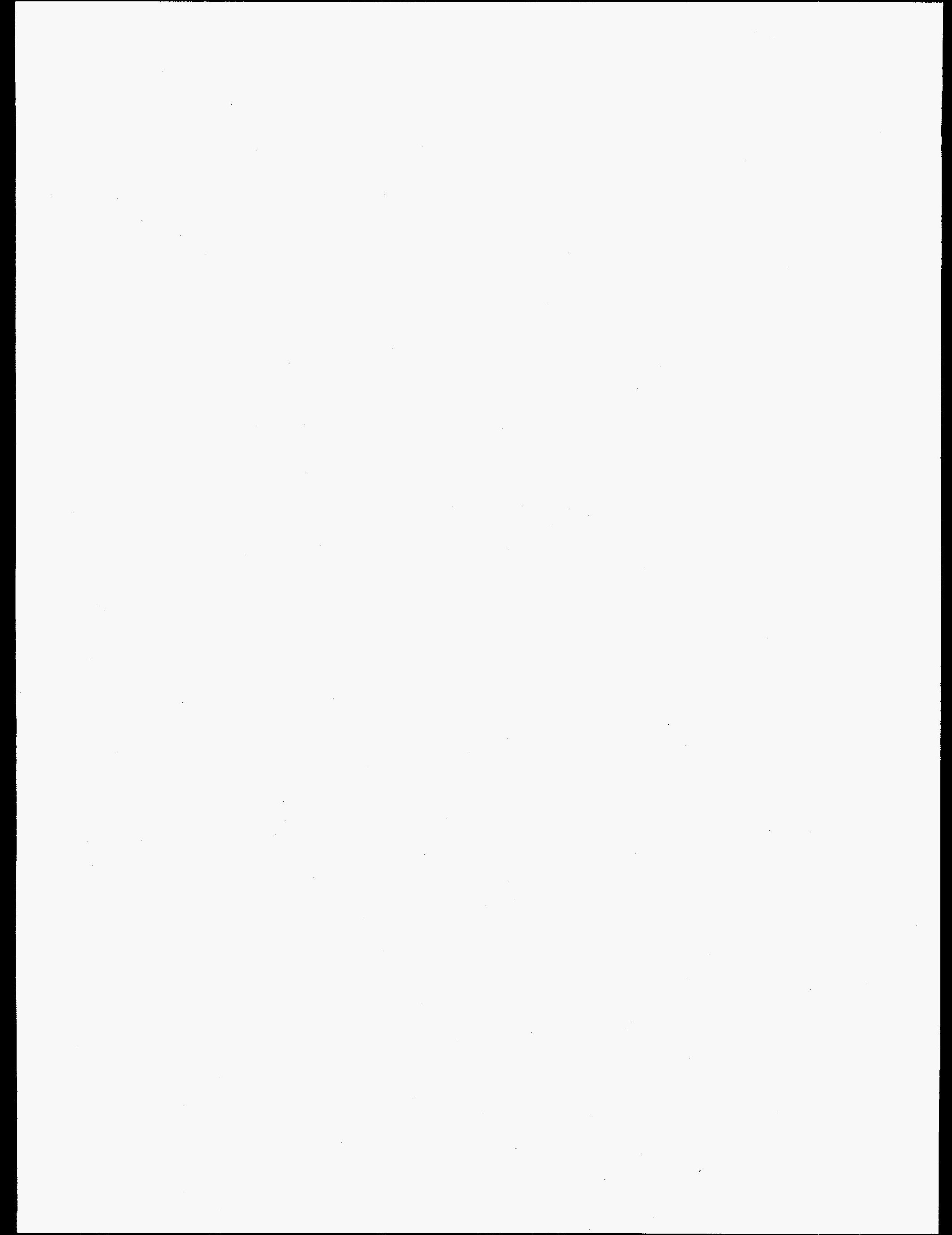




\section{EXECUTIVE SUMMARY}

The purpose of the Old Hydrofracture Facility (OHF) Tanks Contents Removal Project is to remove the liquid low-level waste from the five underground storage tanks located at OHF and transfer the resulting slurry to the Melton Valley Storage Tanks facility for treatment and disposal.

Among the technical objectives for the OHF Project, there is a specific provision to maintain personnel exposures as low as reasonably achievable (ALARA) during each activity of the project and to protect human health and the environment. The estimated doses and anticipated conditions for accomplishing this project are such that an ALARA Plan is necessary to facilitate formal radiological review of the campaign. This ALARA Plan describes the operational steps necessary for accomplishing the job together with the associated radiological impacts and planned controls. Individual and collective dose estimates are also provided for the various tasks. Any significant changes to this plan (i.e., planned exposures that are greater than $10 \%$ of original dose estimates) will require formal revision and concurrence from all parties listed on the approval page. Deviations from this plan (i.e., work outside the scope covered by this plan) also require the preparation of a task-specific ALARA Review that will be amended to this plan with concurrence from all parties listed on the approval page. 


\section{INTRODUCTION}

The Old Hydrofracture Facility (OHF) at the Oak Ridge National Laboratory (ORNL) was used to dispose of liquid wastes by mixing with grout and injecting the waste into deep shale formations. Injection operations were terminated in 1980. There are five underground storage tanks that were used to temporarily store the liquid waste before mixing with grout and injecting. The tanks presently contain approximately 52,000 gal of radioactive sludge and liquid. Recent analytical information indicates that the tanks contain several thousand curies of transuranic waste, longerlived fission products, and fissile radionuclides. The sludge contains the majority of radioactivity. The OHF Tanks Contents Removal Project will remove the liquid low-level waste (LLLW) from the five underground storage tanks and transfer the resulting slurry to the Melton Valley Storage Tanks (MVST) Facility for treatment and disposal.

Among the technical objectives for the OHF Project, there is a specific provision to maintain personnel exposures as low as reasonably achievable (ALARA) during each activity of the project and to protect human health and the environment. The estimated doses and anticipated conditions for accomplishing this project are such that an ALARA Plan is necessary to facilitate formal radiological review of the campaign. This ALARA Plan describes the operational steps necessary for accomplishing the job together with the associated radiological impacts and planned controls. Individual and collective dose estimates are also provided for the various tasks. Any significant changes to this plan (i.e., planned exposures that are greater than $10 \%$ of original dose estimates) will require formal revision and concurrence from all parties listed on the approval page. Deviations from this plan (i.e., work outside the scope covered by this plan) also require the preparation of a task-specific ALARA Review that will be amended to this plan with concurrence from all parties listed on the approval page.

Table 1.1. ALARA goals for the OHF Tanks Contents Removal Project

\begin{tabular}{ll}
\hline \multicolumn{1}{c}{ Category } & \multicolumn{1}{c}{ ALARA goal } \\
\hline Internal dose & No worker receives a measurable/confirmed internal radiological dose \\
Worker exposure & $\begin{array}{l}\text { Less than } 600 \text { mrem maximum annual total effective dose equivalent (TEDE) } \\
\text { for any radiological worker on the project } \\
\text { Less than } 5000 \text { mrem for any extremity, organ, or tissue (including skin) } \\
\text { dose for an exposed worker within a calendar year }\end{array}$ \\
& $\begin{array}{l}\text { No releases in a quantity greater than a reportable quantity (RQ) pursuant to } \\
\text { Environmental Releases }\end{array}$ \\
& $\begin{array}{l}\text { All liquid discharges will be in accordance with applicable provisions in the } \\
\text { Clean Water Act }\end{array}$ \\
\hline
\end{tabular}




\section{ALARA POLICY}

ALARA is the radiation protection approach to manage and control exposure (both individual and collective) to the work force and to the general public to levels that are as low as is reasonable, taking into account social, technical, economic, practical, and public policy considerations. ALARA is not a dose limit but a process that has the objective of attaining doses as far below the applicable established federal limits as is reasonably achievable.

It is the policy of CDM Federal Programs Corporation (CDM Federal) to manage and oversee the onsite radiological work activity for which CDM Federal has direct safety and health responsibility in a way that consistently applies the principles of ALARA. CDM Federal recognizes that the responsibility for ALARA is shared between management, engineering and fabrication disciplines, corporate health and safety, operations personnel, and its contractors. All workers have the authority to stop work when it is perceived to be out of the scope of written instructions, unsafe, or not in keeping with CDM Federal's ALARA policy. CDM Federal's commitment to ALARA will be evident in the following ways.

(1) Employee and contractor radiation exposures will be accurately estimated and managed in a way that fosters ALARA principles. Workers will be required to stay current with bioassay schedules and to properly care for personnel dosimeters. CDM Federal will maintain close communication with organizations providing dose estimates and ensure that internal and external dosimetry estimates are provided by accredited programs.

(2) Radiological work will be carefully planned to keep potential exposures ALARA. The pertinent details within a task will be outlined in a way that provides for accurate radiation exposure estimates. The operation will also make use of pre-job and post-job briefings, cold test dress rehearsal for hot jobs, and incorporate worker suggestions on ways to limit exposure. CDM Federal's project management will ensure that radiological work is properly planned and executed in a manner that ensures worker safety.

(3) Workers will receive training commensurate with the radiological risks of the work. Worker training credentials will be documented, up-to-date, and in accordance with the requirements of the job. Project technical work documents, procedures, and work instructions will be updated as appropriate and properly controlled. Project management will promote awareness of the requirement for verbatim compliance with written instructions where indicated by the job.

(4) For systems that will be used in radiological work, engineered controls will be considered early in the design phase to minimize or eliminate maintenance, minimize and contain leaks, and protect workers from injury or significant exposure to airborne contamination or radiation exposure. System design and fabrication phases will continue to investigate ways to promote efficient work (better, faster, safer, etc.) whenever applicable and cost effective.

(5) Proper facilities and equipment will be provided for supporting efficient and high quality operations for radiological projects. Workers will be supplied with proper protective clothing and equipment with sufficient inventory to support all necessary activities, including emergency response. The selection and placement of facilities and equipment will incorporate sufficient radiation shielding, distance from radiation sources, adequate ventilation, enclosure, 
climate control, lighting, etc., to promote efficient work and minimize maintenance efforts and breakdown potential.

(6) As described in the Safety Analysis Report for the OHF Project (Energy Systems 1997b), process control, pollution abatement, and mitigation systems will be sufficient to prevent any likely or credible environmental release that would result in serious environmental degradation or health risk to the public. Double containment will be incorporated into the design where applicable. Workers will construct catch basins, spread plastic, etc., to prevent or mitigate potential spills and releases. System operators will take precautions to rinse and air dry systems before line breaks to minimize the presence of contaminated liquids. Operations personnel will incorporate leak detection capabilities in the fabricated system. Operational plans will include routine leak detection and mitigation instructions. Work will also be performed in a way that minimizes the spread of radioactive contamination and the generation of radiological waste.

(7) Management commitment to ALARA will be demonstrated through a visible oversight program. Managers will participate in periodic walkdowns of radiological work sites and review radiological performance indicators.

In providing health and safety oversight to the OHF Project, CDM Federal will make every reasonable effort to maintain worker exposures as far below the dose limits as is practical, consistent with the objectives of the project, taking into account the state of technology, the economics of engineered controls and improvements in relation to the benefits to worker health and safety. Planning for each task will take into account the potential for unplanned exposures or radiological releases and will incorporate provisions contained in the Contingency Plan for the OHF Project (Energy Systems 1996) as appropriate. 


\section{OHF PROJECT OPERATIONS}

The OHF Project involves four distinct operational phases. The first operational phase will be a cold test demonstration at the ORNL Tanks Technology Cold Test Facility (TTCTF). The second phase involves site preparation and transferring and installing the sluicing and pumping system at the OHF site when a successful cold test is demonstrated. Operations that include sluicing, pumping, and transferring the slurry to the MVST are part of the third phase. The fourth and final operations phase includes deactivating and demobilizing the system at the conclusion of the project. An ALARA Review prepared to govern the installation of riser spools and submersible pumps during the early steps of the OHF site preparation phase is presented in Appendix A. Appendix B contains the ALARA planning documentation for the remaining tasks in the campaign, including site preparation and system installation, and sluicing and pumping operations. ALARA planning documentation for system deactivation will be developed near the end of the campaign when the final disposition of the equipment is more certain.

\subsection{COLD TEST}

Although the cold test does not require radiological work, there are some activities that fit into the project ALARA strategy. The cold test will demonstrate the performance of the sluicing and pumping system, fine-tune operating instructions, and train personnel on the actual work to be performed (Cold Test Plan for the OHF Project, Energy Systems 1997a). During the cold test, all main system components will be tested except for the ventilation skid and mixer. The TTCTF does not have provisions for installing the mixer in a test configuration.

In addition to system operations, workers will train on several maintenance tasks that may be necessary during operations at the OHF site. The OHF operational strategy and work instructions are contained in the Operations Plan (Energy Systems 1998). In cases where maintenance or repair tasks may involve significant radiological hazards, workers will train using personal protective equipment (PPE) and practice appropriate radiological controls. Several tasks may also be videotaped for reference and use during pre-job briefings.

\subsection{EQUIPMENT INSTALLATION AND MOBILIZATION}

This phase involves activities at the OHF site to prepare the sluicing and pumping system for operation. Since the OHF site is characterized with significant radiation levels and contamination, many activities will be controlled as radiological work and will be covered by a radiological work permit (RWP). An Office of Radiation Protection (ORP) radiological control technician (RCT) will provide continuous job coverage support for radiological work. The Site Safety and Health Officer (SSHO) is responsible for providing continuous Environmental, Safety and Health (ES\&H) support for all field activity at the OHF site. Readiness determination activity will also be concurrent with this phase and cold test. The following tasks will be accomplished during this phase:

- perform site preparation and civil work;

- establish preliminary electrical service;

- set ventilation skid, ductwork, and demister drain line; 
- install riser spools, submersible pumps, and mixer;

- $\quad$ set remaining skids;

- install transfer box connection to the MVST LLLW valve box;

- install instrumentation and controls;

- $\quad$ transfer sluicing and pumping system from cold test to the OHF site;

- plumb and wire site;

- install bubblers, cameras, and sluicer;

- pressure test system; and

- place site shielding.

Not all tasks involve radiological work that could potentially result in significant radiological doses. Appendix B contains the ALARA planning documentation for those tasks where an evaluation of work practices can help to keep personnel radiological exposures ALARA. These tasks include:

- install final riser assemblies and mixer,

- open ventilation connections to risers, and

- install bubbler tubes.

\subsection{SLUICING AND PUMPING OPERATIONS}

Once sluicing and pumping operations begin, several activities will be included under routine operations. Two tanks will be initially involved in the first phase of sluicing: the mixing tank T-9 and tank T-3. Before the tanks are sluiced, supernate from T-2 and T-4 will be transferred to T-9 to ensure that there is sufficient liquid to form a slurry that can be pumped to MVST without settling or clogging the transfer line. A camera will be installed to monitor the liquid transfers to ensure that the sludge will not be disturbed during the pumping. The two subject tanks, T-3 and T-9, are then denatured to adjust the isotopic ratios of nonfissile to fissile material. After the contents of both tanks are removed and pumped to the MVST, the affected portions of the system are purged with process water or reserve supernate.

The next step in the operational strategy involves transferring excess supernate from $T-4$ and $T-1$ to the now empty $T-3$. Once the supernate added to $T-3$ is denatured, it will be reserved for system flushing and will be available to use in tank sluicing if necessary. Then the sluicer and camera will be transferred to the next subject tank. This phase includes activities associated with routine sluicing and pumping before withdrawing the sluicer and camera for the next tank. In addition to moving the sluicer and camera, the following activities are also considered as part of routine operations:

- inspections,

- manual valve adjustments,

- perform tank level measurements and denaturing,

- lowering submersible pumps with hand crank,

- moving the sluicer and camera between tanks,

- moving the dry well radiation detector, and

- dismantling the mixer for sluicing the mixing tank T-9.

Key operational tasks that could potentially result in significant radiological doses involve any operation where tank risers are opened and contaminated components are removed. Appendix B 
contains the ALARA planning documentation for those tasks where an evaluation of work practices can help to keep personnel radiological exposures ALARA. These tasks include:

- installing and removing tank cameras and

- installing and removing the sluicer.

\subsection{OPERATIONS MAINTENANCE AND REPAIR ACTIVITIES}

The system was designed with redundant key components such that the projected life of the system far exceeds the anticipated duration of the project schedule. There is an unlikely potential that maintenance or repair of system components may be necessary after sluicing and pumping operations begin. Cold test preplanning exercises have been performed and work instructions have been developed for the following maintenance tasks:

- Work Instruction 11, "Strainer Basket Changeout,"

- Work Instruction 16, "Rupture Disk Replacement,"

- Work Instruction 17, "Ventilation System Filter Changeout,"

- Work Instruction 18, "Ventilation System Mist Eliminator Wire Mesh Pad Replacement."

A maintenance and calibration plan has been developed to provide guidelines and checklists that will be used in performing vendor-recommended routine and preventive maintenance on various system components. Since the duration of the removal action is expected to be approximately two months, the maintenance and calibration frequencies are limited to daily, weekly, or monthly. Tasks include such activities as simple visible inspections for low oil levels, tightening loose bolts, checking for leaks, checking for clogged filters, or cleaning indicator windows.

Some of these maintenance and inspection tasks will require brief access to areas onsite where radiation levels or contamination may be significant. Radiological control measures will be enforced in such cases where there is a potential for surface contamination, airborne contamination, and significant dose rates. If it is determined that these routine activities contribute to greater than $10 \%$ of the projected dose limits in this plan, a task-specific ALARA Review for maintenance and inspections will be amended to this plan. Major maintenance and repair tasks, such as those requiring work instructions, will also require a task-specific ALARA Review to be amended to this plan before the work is authorized.

\subsection{DEACTIVATION AND DEMOBILIZATION}

Current plans for deactivating the site after the tanks contents are removed to the greatest extent practical include thoroughly flushing and air drying the system before breaking down the connections between skids. There is some indication that the equipment may be useful for subsequent projects. As the deactivation strategy becomes finalized, specific dose estimates and ALARA planning documentation will be prepared and amended to this plan. 


\section{FUNCTIONAL ROLES AND RESPONSIBILITIES}

\subsection{ALARA ENGINEERING GROUP REPRESENTATIVE}

- Acts as the principal contact with the ORNL ALARA Program

- $\quad$ Recommends updates and modifications to the OHF Project ALARA Plan as required

- Works closely with the RCT and OHF project personnel to assist in job planning and evaluating ALARA implementation during the project

- Assists in preparing worker exposure estimates by reviewing work plans, and approves RWPs when higher exposure levels are anticipated

- Provides and maintains electronic pocket dosimeters for assisting in managing personnel radiation exposures

- Provides technical support in calculating dose estimates for complex exposure scenarios.

\subsection{RADIOLOGICAL CONTROL TECHNICIAN}

- Assists the SSHO and OHF project management team by providing radiological control support and advising in project planning, site setup, and operations

- Keeps the SSHO continuously informed of the site radiological conditions

- Provides input to exposure estimates used in tracking worker doses for radiological work

- Works closely with the SSHO and Field Operations Superintendent when preparing and securing approval for RWPs that incorporate ALARA principles

- Responsible for radiological control oversight and establishing an adequate boundary control process, including supervising the placement of the boundary control station, shielding, change trailer, equipment lay down areas, decontamination areas, etc.

- Secures and operates the necessary portable radiation survey instruments and performs all necessary radiological surveys (e.g., surveillance during the project, validate and adjust radiological postings, and contamination release surveys of equipment and tools)

- Provides airborne contamination monitoring by securing and operating continuous air monitors (CAMs), performing calculations to determine derived air concentration values, and participating with decisions on PPE requirements (including respiratory protection)

- Secures and dispenses specialized dosimeters such as extremity or neutron dosimeters if required 
- Participates and provides input into pre-job and post-job briefings

- Manages all radiological postings for the project by providing signs, stanchions, chains, etc.

- Provides job coverage during radiological work

- As required for sluicing and pumping during extended shifts, delegates radiological control to a qualified RCT, etc., and provides adequate job turnover between shifts

- Assists in coordinating the packaging, labeling, and disposal of radiological waste routinely generated during the course of the project.

\subsection{SITE SAFETY AND HEALTH OFFICER}

- Responsible for approving radiological control measures implemented by the RCT for projectrelated activities at the $\mathrm{OHF}$ site

- Ensures that all project-related site activity (by any person, visitor, worker, etc.) is in accordance with an approved RWP and within the scope of approved safety documentation

- Ensures that all workers and visitors satisfy training requirements listed in the Site-Specific Health and Safety Plan (HASP) (Energy Systems 1997c) commensurate with their planned work activity and access needs before site access is granted

- Reviews RWPs and ensures that all required safety permits are approved, reviewed, and signed by workers before any job begins

- Accumulates exposure histories and trends information to compare with project ALARA goals and provides periodic reports to project management staff

- Conducts pre-job and post-job briefings and coordinates with field staff and foremen in job planning to ensure that all proper safety and ALARA controls are addressed and implemented

- Ensures that the RCT is kept informed of all operational planning meetings, briefings, and discussions

- Ensures that employees comply with bioassay and whole body count requests

- Issues and maintains an available inventory of PPE (in proper assortment of sizes, etc.) and safety equipment adequate to ensure efficient project operations

- Maintains easily accessible files of all project-related safety documentation and posted operator aids

- Conducts frequent (daily, weekly, etc.) inspections and walkdowns to ensure that project operations are safe and in accordance with ALARA requirements and commitments 
- Maintains field log of all significant activity

- Maintains a log of all visitors and personnel involved in official inspections or appraisals

- Follows the chain of command for reporting health and safety issues or incidents

- Ensures that waste generated by the project at the OHF site is handled, stored, labeled, etc., in accordance with the project waste management plan.

\subsection{FIELD OPERATIONS SUPERINTENDENT}

- Keeps the SSHO informed of any changes in day-to-day operations that may affect work plan, schedule, personnel changes, etc., that may impact personnel exposure estimates, job planning, or ALARA implementation

- Ensures that all workers are trained and read, sign, and fully comply with all RWP requirements and participate in job planning, pre-job, and post-job briefings

- Follows the direction of the SSHO or the RCT

- Immediately suspends work any time they suspect that radiological conditions may have adversely changed, and seeks the direction of the SSHO or RCT any time radiological control measures are not clearly defined or fully understood

- Ensures that RWP provisions are discussed with personnel prior to work

- Directs site activities such that the generation of radiological waste is minimized

- Maintains dedicated tools in a designated tool crib and ensures that tools are properly identified, stored, and inventoried on a weekly basis

- Requires that work instructions are approved, current, and accurate before performing radiological work

- Verifies completion of steps for tasks accomplished through the use of Work Instructions.

\subsection{WORKERS PERFORMING RADIOLOGICAL WORK}

- Take responsibility for maintaining their radiological exposures ALARA

- Avoid entering any radiological area unless they are certain they satisfy all access requirements or are escorted by a qualified individual

- Read, understand, sign, and comply with all RWP provisions and requirements

- Comply with all dosimetry and bioassay requirements, including: 
- correctly wearing and storing the dosimeters;

— immediately reporting lost dosimeters; and

_ promptly complying with bioassay sample requests.

- Suspend work immediately whenever:

- radiological conditions have adversely changed;

- significant questions about radiological controls arise;

- it is recognized that work is out of scope, not included in job planning, or not covered by the RWP; or

- dosimeter is lost, damaged, etc., during radiological work.

- Properly don and doff protective clothing as directed by the RWP

- Properly frisk upon exit

- Do not remove materials, tools, equipment, etc., from a radiological area without proper tagging and guidance from the RCT.

\subsection{CDM FEDERAL PROJECT MANAGER}

- Ensures that all radiological work under CDM Federal's direction will be in accordance with approved RWP

- Provides sufficient equipment, facilities, PPE, and supplies to ensure safe, efficient, and quality work at the job site

- Interfaces with the ORNL Site Project Manager and ALARA Engineering Group Representative for resolving ALARA issues that may arise between the RCT and SSHO.

\subsection{ORNL SITE PROJECT MANAGER}

- Responsible for ensuring that all ORNL-supplied technical support, equipment, supplies, power, etc., are provided in a way that provides for adequate job planning and scheduling

- Interfaces with the CDM Federal Project Manager and RCT for resolving ALARA issues

- Implements traffic control measures required to protect the transfer line connection to the MVST valve box and the road directly adjacent to the OHF site during sluicing and pumping operations. 


\section{CONDUCT OF OPERATIONS AND GOOD PRACTICES}

\subsection{PRE-OPERATIONAL ACTIVITY}

- All radiological work at the OHF will be controlled by an approved RWP. The RWP, posted at the designated boundary control station for the site, must be read, understood, and signed by all workers involved in the specific task. The RWP should be specific for the task or have specific language that addresses the activities to be performed in the task. A worker signature on the RWP formalizes their agreement to obey all provisions.

- An ALARA briefing will be incorporated with the pre-job briefing at the beginning of work activities each day. The daily ALARA briefing may be conducted by the SSHO or the RCT. Appendix C contains an example of Daily ALARA Pre-Job Briefing Topics that should be used. Although daily briefings should be kept informal and be included as part of the health and safety briefings, attendance sheets will be maintained. Workers not present during the briefing must receive an individual briefing by the SSHO before they begin work at the OHF site.

- An ALARA Operations Review will be conducted at the beginning of OHF field operations (i.e., tasks covered in Appendix B). The ALARA operations review checklist may be completed by the SSHO or the RCT. Appendix D contains an example of an ALARA Operations Review Checklist for OHF Field Operations that should be used before a task with a potential for significant radiological exposure is initiated.

- Access to the job site will be controlled by the SSHO. The activities and number of workers will be consistent with the original job plan and the Site-Specific HASP (Energy Systems 1997c). The SSHO will maintain adequate control of work activity at the site by limiting the number of workers, the placement of vehicles and equipment, the location of stored materials, etc. The Field Operations Superintendent will cooperate with the SSHO in keeping the job site free of unnecessary personnel.

- Materials that are not necessary for a specific function in the Exclusion Zone will be prohibited from entering the area.

- Plastic should be placed around the opening any time a tank riser is opened, regardless of the flange size. Once sluicing and pumping operations have begun, the ventilation system must be operating during any tank riser opening.

- At the completion of each job, materials, tools, and equipment will be segregated and surveyed by the RCT before removing from the site. Since a dedicated tool crib will be maintained within the Radiological Area, tools should only be removed from the area when necessary.

- The correct PPE as indicated by the RWP and HASP will be available and stored at the work site in the change trailer. Air-purifying respirators (APRs) and cartridges will be provided by the SSHO. Workers are not permitted to provide their own respirators as an alternative. 
- Work clothing such as hard hats, rubber boots, gloves, etc., dedicated for reuse at the site will be stored in the radiological buffer area. Such articles will be surveyed for contamination after each use.

- Used APRs and cartridges are to be placed in the appropriate container at the step-off pad after each use.

- Fissile Control Area extends at least $15 \mathrm{ft}$ from the tank centerline and at least $10 \mathrm{ft}$ from the tank ends until the tank contents has been denatured.

\subsection{SITE SHIELDING AND ROAD BLOCKS}

- The placement and movement of the frisk shield must be coordinated with the SSHO, RCT, and Field Operations Superintendent to insure that location will not inhibit the movement of equipment and will provide a low background area for frisk-out at the radiological area boundary control station.

- The placement of highway barriers must be approved by the OHF Facility Manager. The SSHO, RCT, and Field Operations Superintendent must approve the placement of highway barriers (including placement for storage). Highway barriers may be used for the following purposes:

- shielding for south access road,

- barricade and shielding for transfer line, and

- temporary road blocks.

- The SSHO and RCT will determine the need for temporary use of lead blankets and the RCT will oversee the installation, use, and removal of any temporary shielding.

- The Field Operations Superintendent will approve the placement of lead blankets on or against systems and components and will evaluate whether the additional weight or covering may affect the performance or structural integrity.

\subsection{DEDICATED TOOL CONTROL}

- A small assortment of tools with orange handles will be maintained primarily for use in Contamination, High Contamination, or Airborne Radioactivity Areas. The tools will be maintained in a designated "dedicated tool" crib.

- The Field Operations Superintendent will control the issuance and inventory of dedicated tools.

- Dedicated tools should not leave the Radiological Area unless necessary for disposal or for use in another Contamination Area. The movement of dedicated tools must be controlled by an RCT. 
- The SSHO and RCT must be consulted before tools are brought into or removed from the Radiological Area. Non-dedicated tools used in the Radiological Area must be surveyed by the RCT upon leaving the area.

\subsection{WASTE MINIMIZATION}

- Material entering radiological areas will be restricted according to what is necessary for performing work.

- Quantities of solvents, adhesives, fuels, etc., will be restricted to the smallest amount necessary to complete the job. Additional amounts may be kept outside the radiological area boundary.

- $\quad$ Reusable items such as tools, APRs, boots, gloves, tape, etc., should be segregated at the stepoff pad.

- Waste will be segregated and removed from the site as directed by the RCT and in accordance with the project waste management plan.

\subsection{TRAINING AND QUALIFICATIONS}

- The training requirements for the OHF Project are defined in the OHF Site-Specific HASP, Table 10.1 (Energy Systems 1997c).

- Workers entering the Radiological Area are required to have Radiological Worker II training.

- Anyone approved to enter the Fissile Control Area without a trained escort must be at least Level-0 Nuclear Criticality Safety (NCS) trained.

\subsection{NUCLEAR CRITICALITY SAFETY APPROVAL REQUIREMENTS}

- Maintain compliance with all provisions contained in the NCS Approval (NCSA) No. 56, dated May 22, 1997. The NCSA includes provisions for the following:

- above-ground and in-tank preparation for sluicing and removal,

- sluicing with OHF liquid or nonfissionable-material liquid,

- adding compound(s) of depleted uranium for isotopic dilution,

- transfer of waste among OHF tanks, and

- transfer of isotopically diluted waste from OHF tanks to the active LLLW system.

- Any operation that could significantly concentrate the sludge into a small volume or remove most of the water from the sludge is prohibited by the NCSA. The system operators shall maintain liquid covering over the sludge in all tanks. There is no minimum depth as long as the sludge remains covered. 
- There will be no transfer of fissionable-material sludge from either tank $T-3$ or $T-4$ to any other tank ( $T-1, T-2$, or $T-9)$ unless the fissionable material in the tanks ( $T-3$ or $T-4)$ has been isotopically diluted (denatured). Once the tank contents are denatured, the waste is no longer considered fissionable material and the conditions of approval (COA) in the NCSA no longer apply to that tank.

- Any proposed addition of chemicals to the tanks needs Facility Manager approval and must be independently reviewed by ORNL chemists or chemical engineers to ensure that the operation will not cause uranium or plutonium to separate from the waste.

- If any NCSA COA is violated, the SSHO will be immediately notified. The SSHO will ensure that no workers are in the vicinity of the OHF tanks. The Field Operations Superintendent will oversee any additional measures necessary to safely secure the sluicing and pumping system and field equipment. No further action should take place until directed by the ORNL NCS Section or Facility Manager.

- The Facility Manager (or designate) shall notify the NCS Section as soon as practical in case of an NCS incident or violation of an NCSA COA. The confirmation that waste is leaking (or has leaked) from a tank shall initiate NCS Section notification in addition to the emergency notifications identified in the Site-Specific HASP (Energy Systems 1997c). 


\section{CONTINGENCIES}

Several contingencies are addressed in the following project documents:

- $\quad$ Site-Specific HASP for the OHF Project (Energy Systems 1997c)

- Contingency Plan for the OHF Project (Energy Systems 1996)

- Safety Analysis Report for the OHF Project (Energy Systems 1997b)

The most significant episodes analyzed include such events as tank ruptures, high pressure sluicer line breaks, tank overflows, and nuclear criticality. In all cases, the process control equipment and administrative controls are likely to prevent these extremely unlikely occurrences from ever reaching the hazardous proportions analyzed. Chapter 7 of the Site-Specific HASP discusses the evacuation plan and route in more detail. The following contingencies are addressed:

- nuclear criticality;

- $\quad$ radioactive liquid waste spill;

- $\quad$ tank overflow, leak, or rupture;

- $\quad$ transfer line leak or rupture;

- $\quad$ sluicing equipment leak;

- ventilation system malfunction; and

- ORNL emergency alarm.

If an ORNL emergency alarm sounds, the SSHO will ensure that work stops immediately and that all workers are aware of the alarm and are taking the appropriate action. The Field Operations Superintendent will ensure that all equipment is secure and shutdown in a safe state. 


\section{HOLD POINTS}

\subsection{TASK-SPECIFIC HOLD POINTS}

Hold points are identified for each task where there is uncertainty in the anticipated dose projection. The dose estimates are based on anticipated radiation fields. The RCT will verify the radiation fields before each task to ensure that the measured field is within the projected levels. There may be several hold points within a task as work proceeds. Examples of hold points are as follows:

- gamma exposure rate and airborne contamination measurements at the beginning of radiological work,

- task-specific personnel dose limits,

- gamma exposure rate measurements at each riser opening, and

- pump skid dose rate measurements before access.

\subsection{PERSONNEL DOSE LIMITS}

\section{0 mrem - Hold Point}

If it is determined from Energy Systems dosimetry information that an individual worker has received approximately $200 \mathrm{mrem}$ cumulative exposure, the SSHO and RCT will conduct an informal evaluation to verify the source of the dose and take the following action:

- The worker's job responsibilities will be reviewed and potential reassignment to low exposure activities may be recommended.

- A re-evaluation and characterization of the site radiation fields will be performed to ensure that the radiation areas are well defined.

- The worker will be briefed to reinforce good ALARA practices.

- An informal evaluation report will be prepared by the SSHO and submitted to project management (ORNL Environmental Restoration Site Project Manager and CDM Federal Project Manager).

- The RCT will notify the ORNL ORP.

\section{0 mrem - Hold Point}

When it is determined that a worker received $400 \mathrm{mrem}$, the ORP will be consulted to assist in verifying the dose estimate and to advise in proposing measures to reduce future exposures. The 
SSHO and RCT will conduct an investigation to verify the work practices that contributed to the dose and take the following action:

- The worker is reassigned to low exposure activities until the outcome of the investigation and written approval from OHF project management (ORNL Environmental Restoration Site Project Manager and CDM Federal Project Manager) to continue radiological work.

- An evaluation and characterization of the site radiation fields will be performed to ensure that the radiation areas are well defined.

- The OHF project team will be briefed to reinforce good ALARA practices.

- A formal evaluation report will be prepared by the SSHO and submitted to the ALARA Engineering Group, Radiation Surveillance Section Manager, and project management (ORNL Environmental Restoration Site Project Manager and CDM Federal Project Manager).

\section{0 mrem - Maximum Allowed Dose}

No worker is permitted to exceed 600 mrem without ALARA Steering Committee review and approval of the ALARA Working Committee recommendations for this project. Situations where the OHF project may request a worker to exceed $600 \mathrm{mrem}$ will be handled as a separate case beyond the scope of this plan. 


\section{REFERENCES}

Energy Systems (Lockheed Martin Energy Systems, Inc.) 1996. Contingency Plan for the Old Hydrofracture Facility Tanks Sluicing Project at Oak Ridge National Laboratory, Oak Ridge, Tennessee. ORNL/ER-383. Prepared by CDM Federal Programs Corporation, Oak Ridge, Tenn. October.

Energy Systems (Lockheed Martin Energy Systems, Inc.) 1997a. Cold Test Plan for the Old Hydrofracture Facility Tank Contents Removal Project, Oak Ridge National Laboratory, Oak Ridge, Tennessee. ORNL/ER-423. Prepared by CDM Federal Programs Corporation, Oak Ridge, Tenn. November.

Energy Systems (Lockheed Martin Energy Systems, Inc.) 1997b. Safety Analysis Report for the Old Hydrofracture Facility Tanks Contents Removal Action Project at Oak Ridge National Laboratory, Oak Ridge, Tennessee. ORNL/SAR/7852-ER/ER-R0. October.

Energy Systems (Lockheed Martin Energy Systems, Inc.) 1997c. Site-Specific Health and Safety Plan for the Old Hydrofracture Facility Tanks Contents Removal Project at Oak Ridge National Laboratory, Oak Ridge, Tennessee. ORNL/ER-427. Prepared by CDM Federal Programs Corporation, Oak Ridge, Tenn. December.

Energy Systems (Lockheed Martin Energy Systems, Inc.) 1998. Old Hydrofracture Facility Tanks Contents Removal Action Operations Plan at Oak Ridge National Laboratory, Oak Ridge, Tennessee. ORNL/ER-433. Prepared by CDM Federal Programs Corporation, Oak Ridge, Tenn. March. 
Appendix A

\section{ALARA REVIEW-RISER SPOOL AND SUBMERSIBLE PUMP INSTALLATION TASK (REVISION 1.0)}




\section{ALARA REVIEW}

Riser Spool and Submersible Pump Installation Task for the Old Hydrofracture Facility Tanks Contents Removal Project Oak Ridge National Laboratory, Oak Ridge, Tennessee

REVISION 1.0

January 21, 1998

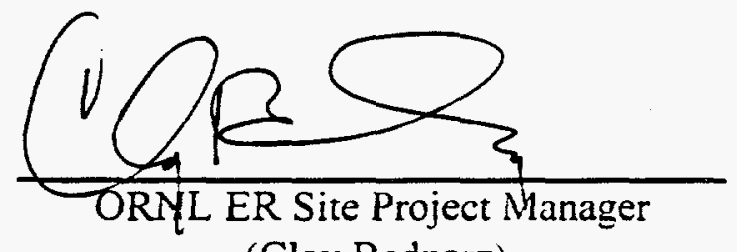

(Clay Bednarz)

Sans $\operatorname{Sat}_{2} 4$ Project Field Superintendent

(Jim LaForest)

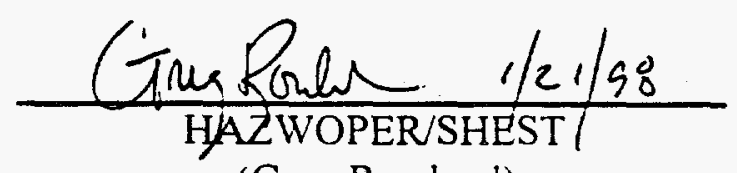

(Greg Rowland)

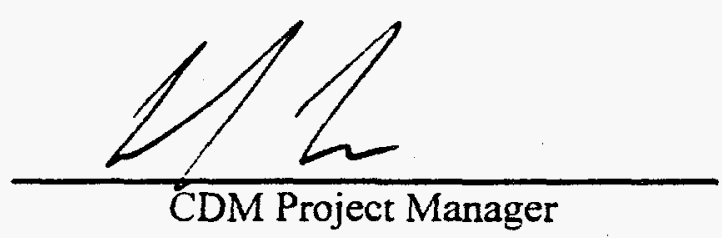

(Charles Callis)
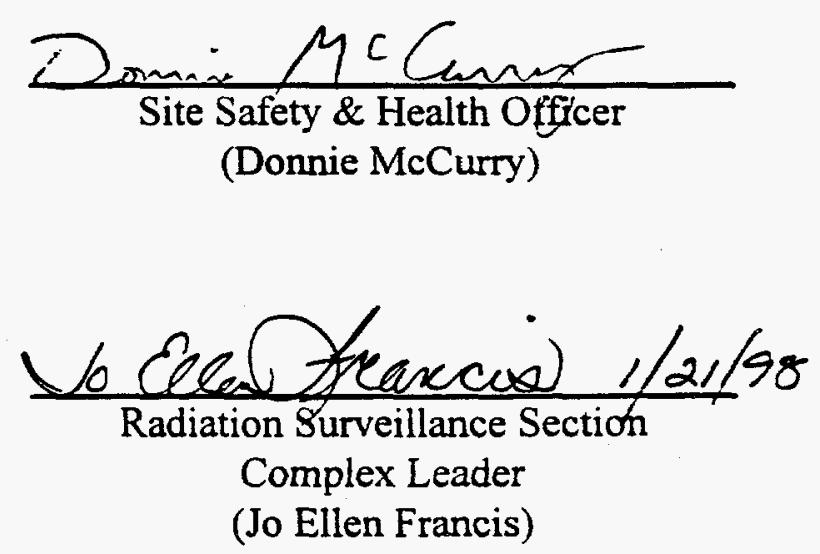

(Jo Ellen Francis)

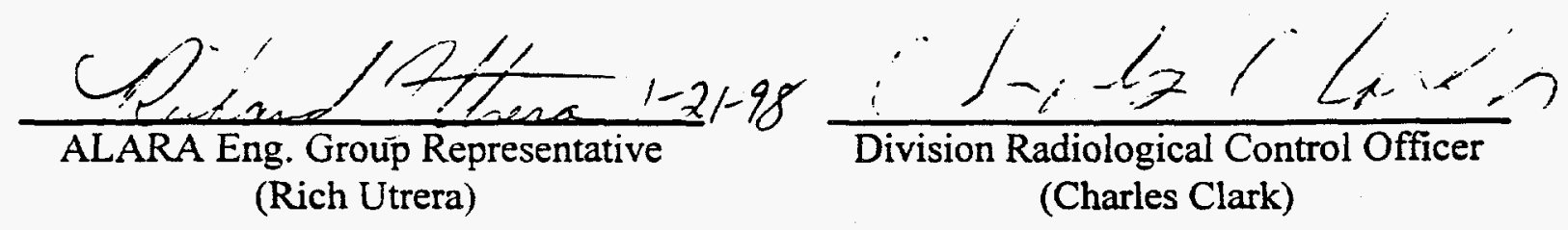




\section{INTRODUCTION}

\section{Background}

The Old Hydrofracture Facility (OHF) at the Oak Ridge National Laboratory (ORNL) was used to dispose of liquid wastes by mixing with grout and injecting the waste into deep shale formations. Injection operations were terminated in 1980. There are five underground storage tanks that were used to temporarily store the liquid waste prior to mixing with grout and injecting. The tanks presently contain approximately $\$ 2.000$ gal of radioactive sludge and liquid. Recent analytical information indicates that the tanks contain several thousand curies of transuranic waste, longer-lived fission products. and fissile radionuclides. The sludge contains the majority of radioactivity. The OHF Tanks Contents Removal Project will remove the Low Level Liquid Waste (LLLW) from the five underground storage tanks and transfer the resulting slurry to the Melton Valley Storage Tanks (MVST) Facility for treatment and disposal.

\section{Task Description}

This task is part of the first phase of field activity for the OHF tanks contents removal campaign. The work involves modifying the tanks by installing riser spools with attached submersible pumps inside four of the five subject tanks. A total of ten spools are necessary for the campaign. However, this task includes installing seven riser spool/pump combinations. The remaining three spools are in use at the cold test mock up. The riser spool installation order for this task will begin with tank T--1 since it has the lowest dose rates. This allows for the opportunity to improve the time to accomplish the repetitive steps when dose rates are higher. The key steps for installing a riser spool/submersible pump combination are as follows:

- Prepare the riser box/spool with submersible pump - The necessary connections between the new riser spool flange and the submersible pumps will be performed in a low background area. All flange openings will be sealed with blind flanges.

- "Hot bolt" riser cover - All bolts on the tank riser flange will be removed except for two or four opposing bolts. Removed bolts will be bagged and stored on-site.

- Vent riser opening - The remaining bolts in the tank riser flange cover will be removed, except for one bolt. so that the lid can be shifted to make a 3 or 4 in. opening to test for negative pressure. The excess bolts will be bagged and stored on-site. The tank should be vented for approximately $15 \mathrm{~min}$. after negative pressure (i.e., operating ventilation system) has been verified.

- Remove flange cover - After the remaining bolt in the flange cover is removed, it will be removed and double bagged. 
- Remove gasket and prepare flange lip - The tank riser flange lip will be prepared to accept the new riser spool. If necessary, the gasket will be removed and the flange surface scraped with a putty knife to provide a clean, flat surface.

- Place gasket and align new riser spool - The new gasket will be attached to the riser spool flange surface during the preparation step. The submersible pump will be lowered into the tank and the new riser spool will be positioned and aligned using two new bolts to line up the holes. The new riser spool will be set on the tank riser.

- Mount riser spool and "hot bolt" - The new riser spool will be "hot bolted" with at least two opposing bolts and the rigging will be removed.

- Complete bolt installation - The remaining bolts will be installed and tightened. New bolts will be used to install the new riser spool.

\section{DOSE ESTIMATES}

The projected collective effective dose for this job is 524 person-mrem. The ORNL routine radiological survey for the OHF site, dated October 18,1997. was used to provide dose estimates for the job (see Attachment 1). There will be three people directly involved in the radiological work. The SSHO and RCT will provide job coverage to support the workers. The ORNL P\&E will provide the hoisting and rigging service. It is planned that the P\&E riggers will hand the tag lines to the workers inside the radiological area as the riser spools are being positioned. The P\&E workers are not included in the collective dose estimate since they will not be entering a Radiation Area. Attachment 2 provides the basis for the pre-job dose estimates and stay times. The maximum whole body dose expected for this job is as follows:

\begin{tabular}{lc}
\hline \multicolumn{1}{c}{ Position } & Whole Body Dose (mrem) \\
\hline Construction Foreman (CSF) & 54 \\
Pipe Fitter \# ( (PF1) & 331 \\
Pipe Fitter \#2 (PF2) & 119 \\
SSHO (SHO) & 10 \\
Radiological Control Technician (RCT) & 10 \\
\hline
\end{tabular}




\section{RADIOLOGICAL HOLD POINTS}

\section{Field Measurements}

The following hold points will be in place for each if the 7 riser spools to be installed.

- Preliminary dose rate measurements at the tank riser - Dose rate measurements will be: made at the unopened tank riser before the beginning of work (i.e., loosening bolts). If the dose rate is unexpectedly high (e.g., greater than $20 \%$ over the expected dose rate), further job planning is necessary before beginning work on the tank riser. For example, the ALARA dose estimates will be revised and precautionary steps may be added to reduce personnel exposure.

- Measurements at the vented tank riser - If the dose rate is unexpectedly high (e.g., greater than $20 \%$ over the expected dose rate), further job planning be necessary to add precautionary steps to reduce personnel exposure. The SSHO will also verify negative pressure at the opening. Level C PPE (with air purifying respirator) will be required when a tank riser is initially opened. If negative pressure cannot be verified or ventilation to the tank is determined to be ineffective, the SSHO and RCT will determine if Level $\mathrm{C}$ is necessary to complete the job.

\section{Personnel Exposure}

Workers will use Siemens electronic pocket dosimeters with the alarm set point at 200 mrern cumulative dose and dose rate set point at approximately $20 \%$ over the maximum expected dose rate. Depending on the alarm. the RCT and SSHO will direct the worker to complete the specific step underway when the alarm sounds. If a worker's cumulative dose triggers an alarm. the RCT and SSHO will advise whether work assignments should be shifted between workers before proceeding. An alarm occurring near the end of the job may not result in work assignment adjustments.

\section{WALKDOWN OR DRY RUN}

Two identical riser spools (one with submersible pump) were installed at the robotics cold test facility to support the cold test mock-up of the sluicing and pumping system.

\section{MAXIMUM PREFABRICATION}

The riser spools and submersible pumps will be configured together before being moved into the radiological area. The only work planned in the radiological area is to be performed on the tank risers. 


\section{STAGING NECESSARY MATERIALS AND TOOLS}

Staging of materials and tools will be outside of the radiological area. With exception to an air impact wrench for bolt removal. no special tools will be necessary. Duplicate tools and additional nuts and bolts will be on hand.

\section{RADIOACTIVE MATERIAL REDUCTION}

Waste materials from the job (e.g., gaskets. nuts. bolts. plastic, PPE, etc.) will be bagged and disposed. Recyclable items. such as rigging and over boots, will be segregated at the step off pad for survey. No unnecessary items will be introduced into the radiological area.

\section{ENGINEERED CONTROLS}

The OHF tanks have an existing ventilation system connected to the tanks. The operational status of the system will be verified. Plastic will be used around each tank riser to minimize the spread of contamination. If breezy or windy conditions persist, a wind break may be constructed to reduce wind velocity across the riser opening.

\section{SPECIAL TOOLING OR WORK PROCESSES}

There are no unique work processes or tooling identified to reduce time in the work area.

\section{TRAINING}

Workers are required to complete Radiological Worker II training and be respirator qualified.

\section{TEMPORARY SHIELDING}

No temporary shielding will be used.

\section{EMERGENCY PROCEDURES AND CONTINGENCY PLANS}

The work will be performed under the guidelines in the Site-specific HASP for the OHF Tanks Contents Removal Project (ORNL/ER-427). If an ORNL emergency alarm sounds, the SSHO will ensure that work stops immediately and that all workers are aware of the alarm and are taking the appropriate action. The Field Operations Superintendent will ensure that all equipment is secure and shutdown in a safe state. Chapter 7 of the Site-Specific HASP discusses evacuation plans and routes in more detail. The following job-specific contingencies are addressed: 
- Damage to a flange surface - A flange surface on either the new riser spool or the tank riser may become damaged during the job due to a crane mishap, etc. The construction foreman will inspect the flange and determine whether a suitable. long-term seal can be maintained after the spool is installed. If the damage to a tank riser flange is significant. the submersible pump should be removed and double-bagged. A flange cover should also be bolted over the riser opening and a layer of plastic should be taped around the top of the covered tank riser: to minimize the potential spread of contamination.

- Damage to a gasket - If a gasket is damaged during submersible pump placement, the construction foreman will inspect and repair as required. If it is certain that the submersible pump has not touched the tank contents, it may be withdrawn and the necessary repairs made. Any necessary gasket repairs should be made without withdrawing the pump after it has touched the tank contents.

- Damage to a submersible pump - If a submersible pump is damaged during placement, the construction foreman will inspect and decide whether the pump is capable of operation. No repairs should be attempted if the pump has touched the tank contents. A damaged pump that came in contact with a riser, etc. should be handled as contaminated material and double bagged.

- Inoperable Tank Ventilation system - If the ventilation system is not operational or is insufficient to maintain minimal negative pressure for the job, a portable system will be used.

- Stubborn bolt - If a bolt is stripped or rusted in a way that prevents quick removal, riser spool installation for that particular tank riser will be postponed. The Field superintendent will need the approval of the SSHO and the RCT if the decision is made to install the riser spool in another tank riser.

- Wind and inclement weather - Wind gusts must not exceed $15 \mathrm{mph}$. The SSHO will monitor the wind conditions and periodically contact the LSS for weather updates. The SSHO will terminate the job if conditions deteriorate in way that prevents safe work or proper deactivation of the worksite. The SSHO will also decide if wind breaks should be used to reduce the wind effects. 
ATTACHMENT 1

ORNL RADIOLOGICAL SURVEY: SAAS-97-0635 


\section{ORNL Radiologicai Survey Data}

Surveyor Badge Number:

30557

Routine Survey

RWP Numbar: SAAS-2033A

Building: OHF

Specific Location: QUARTERLY ROUTINE

Description:

General radological survev of entire UHF area as defined ov the survey maps incluoed in inis routine.

Instruments Used and Calibration Due Date:

\begin{tabular}{rrrrrrr|}
\hline $2652-141$ & $11 / 8 / 97$ & $2652-098$ & $2 / 18 / 98$ & $2652-51 P$ & $222 / 98$ & CTA-033 \\
CTB-039 & $1 / 1 / 98$ & & & & & \\
\hline
\end{tabular}

General Description of Radiological Conditions:

All areas not covered by gravei are SC or CA. RA's surround ponds and 7852. Pad and Pond suit are HC areas. HR found on 7852 root and at stlt levet in oona. CA's found around pumpnouse and on 7852 roof.

Division or Group Needing the Survey:

ER

Person-hours spent on the survey:

16

\# of Pages: Completed By:

Reviewed by:

Dats:

\begin{tabular}{|c|c|c|c|c|c|c|c|c|}
\hline \multicolumn{9}{|c|}{ Smear Resuits (dpm/100 cm uniess noted) } \\
\hline $\begin{array}{l}\text { Smat: } \\
\text { Number: }\end{array}$ & $\alpha$ & Locestion & Smow: & $\alpha$ & Locatuon & $\begin{array}{l}\text { Smeer: } \\
\text { vumber: }\end{array}$ & $\alpha$ & Lecation \\
\hline 11 & 281 & 985:0unser & 2 & $<201$ & $<2001^{1001}$ & 3 & $<201$ & $<2001^{\text {noppent }}$ \\
\hline 41 & $<201$ & 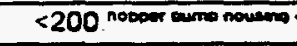 & 5: & $<201$ & $<2001^{\text {noposer man }}$ & 61 & $<201$ & $<2001^{\text {mopoed }}$ \\
\hline 7 & $<20$ & $303^{\text {:00000 moum }}$ & 8 & $<201$ & $<2001^{\text {mopos moum }}$ & 9 & $<201$ & $<2001000000$ \\
\hline 101 & $<20$ & $<200: 090000$ & 11 & $<201$ & 444 ppes cos oneren & 121 & $<201$ & $<2001^{\circ}$ \\
\hline $13 !$ & $<201$ & $<2001^{1000}$ & 14 & $<201$ & $<2001^{\text {rood }}$ & 15 & $<20$ & $<2001^{200}$ \\
\hline $16 \mid$ & $<20$ & $<200$ : & 17 & $<201$ & $<200$ !root & 181 & $<201$ & $<2001^{100}$ \\
\hline 191 & $<20 !$ & $<200^{\text {roor }}$ & 20 & $<201$ & $<200 \mid$ & $21 !$ & $<L L O 12$ & $\mathrm{mrad} / \mathrm{h}=\min _{\sin }^{\sin }$ \\
\hline
\end{tabular}




\section{ORNL Radioiogicail Survey Data}

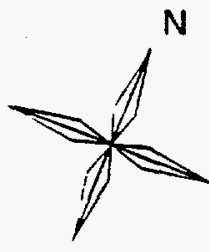<smiles>O=P#P</smiles>

1.0 R/h@contact $100 \mathrm{mR} / \mathrm{h}$

1.5

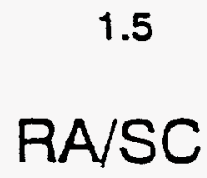

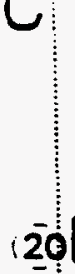
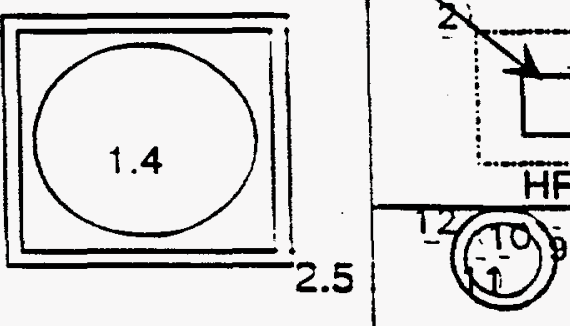

20

\section{5}

RAISC
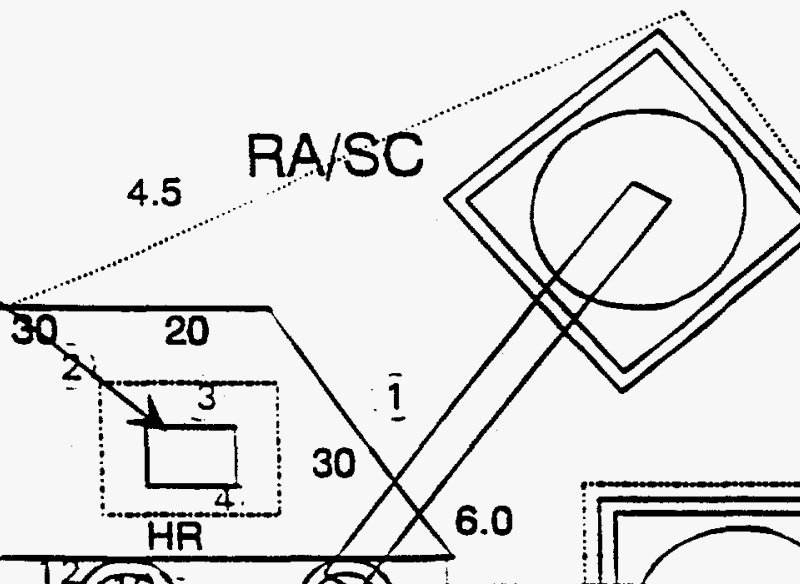

\section{0}

$5:$
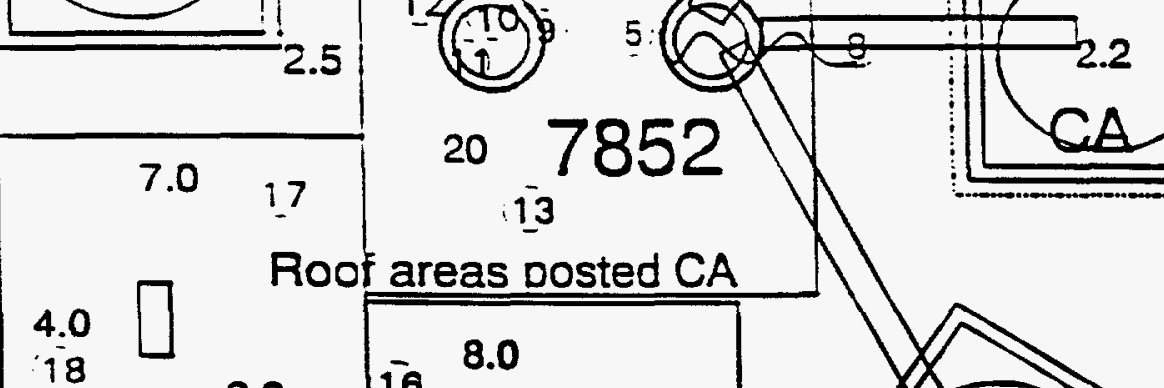

17

Roo<smiles>[AlH2]</smiles>

7852

13

CA

8.0

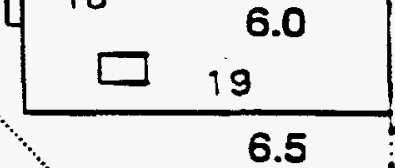

-

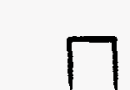

5.0

$0.5-30 \mathrm{mR} / \mathrm{h}$

0.3 - $50 \mathrm{mrad} / \mathrm{h}$

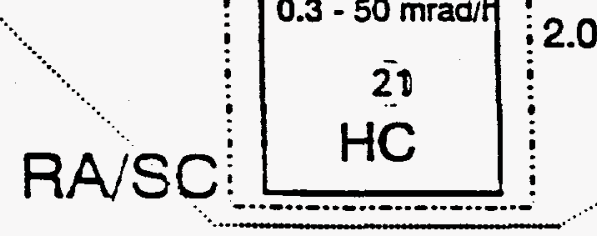

5.0
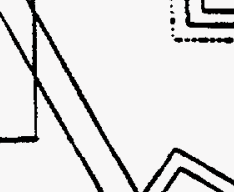

\section{.0}

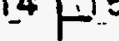

2.0

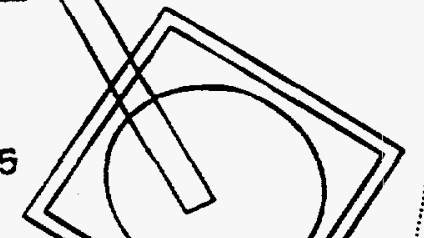

7852 SMEARS LISTED ON SURVEY

\begin{tabular}{|c|c|c|c|}
\hline \# & - Smear Location & \multicolumn{2}{|c|}{ Boundary Designations } \\
\hline$\Theta-\Theta$ & - Large Area Smear & RA - Radiation Area & BA - Radiotogical Buffer Area \\
\hline$\#$ & - Contact Dose Rate & HR - High Radiation Area & CA - Contamination Area \\
\hline 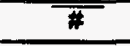 & $.30 \mathrm{~cm}$ Oose Rate & VR - Very High Radiation Area & HC - High Contamination Area \\
\hline \# & - General Area Dose Rate & AR - Airborne Radioactivity Area & FC - Fixed Contamimation direa \\
\hline SOP! & - Step-oif Pad & P I - Potentiat Internat Contamination Area & IC - Intemal Contamination Are \\
\hline AS & - Air Sample Location & UM - Underground Radioactive Material Ar & SC - Soil Contamination Ar \\
\hline
\end{tabular}

The default units for dose rates are expressed in dose equivalent as mremih. If the dose rates are in units ott. than $\mathrm{mrem} / \mathrm{h}$ (e.g., rem/h, umrem/h. etc.), then this shall be noted on the map. Dose rates designated on the $s$ indicate a summation of all the ty pes of radiation detected. unless the indicated dose rate has a typo-identifit with it (e.g., 2G). The type identifiers are as follows: B - Beta, G - Gamma, N - Neutron. Boundary designatior looking from the designations into the zoned area. 


\section{ORNL Radiologicai Survey Data}

\section{OHF East Tank}

5: tubing

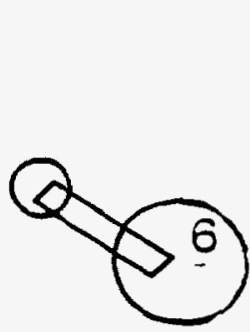

i

\begin{tabular}{|c|c|}
\hline Alpha & Beta-Gamma \\
\hline & \\
\hline- & \\
\hline 11 & 350 \\
\hline 173 & 3264 \\
\hline $5=$ & 208 \\
\hline | 1 | & 207 \\
\hline , & \\
\hline 1 & \\
\hline 0 & \\
\hline 1 & \\
\hline
\end{tabular}

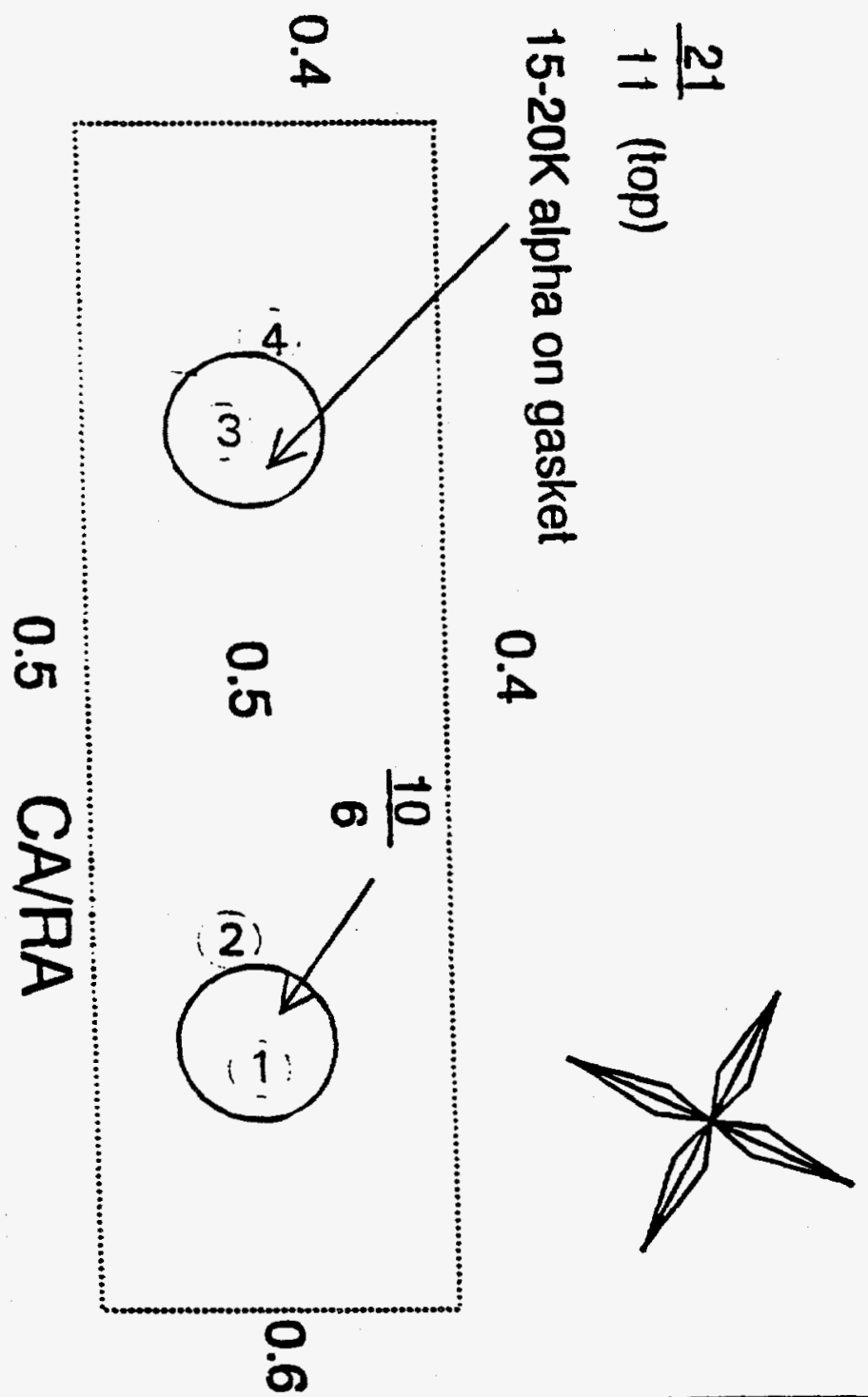

\begin{tabular}{|c|c|c|c|}
\hline (\#) & -Smear Location & \multicolumn{2}{|c|}{ Boundary Designations } \\
\hline 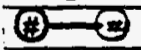 & - Large Area Smear & RA-Radiation Area & BA - Radiological Butfer Area \\
\hline 勧 & - Contact Dose Rate & HR - High Radiation Area & CA-Contamination Area \\
\hline * & - $30 \mathrm{~cm}$ Dose Rate & VR - Very High Radiation Area & HC-High Contamination Area \\
\hline \# & - Generai Area Dose Rate & AR - Airborne Radioactivity Area & FC-Fixed Contamination Ares \\
\hline$\overline{\mathrm{SOP}}$ & - Step-off Pad & Pl-Potential Intemal Contamination Area & IC - Internal Contamination Are \\
\hline AS & - Air Sample Location & \multicolumn{2}{|c|}{ UM - Underground Radioactive Matorial Area SC-Soil Contamination Are } \\
\hline & & & lesignated on \\
\hline
\end{tabular}




\section{ORNL Radioiogicai Survey Data}

\section{OHF East Tank Access North Tank}

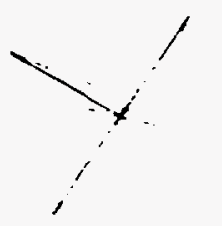

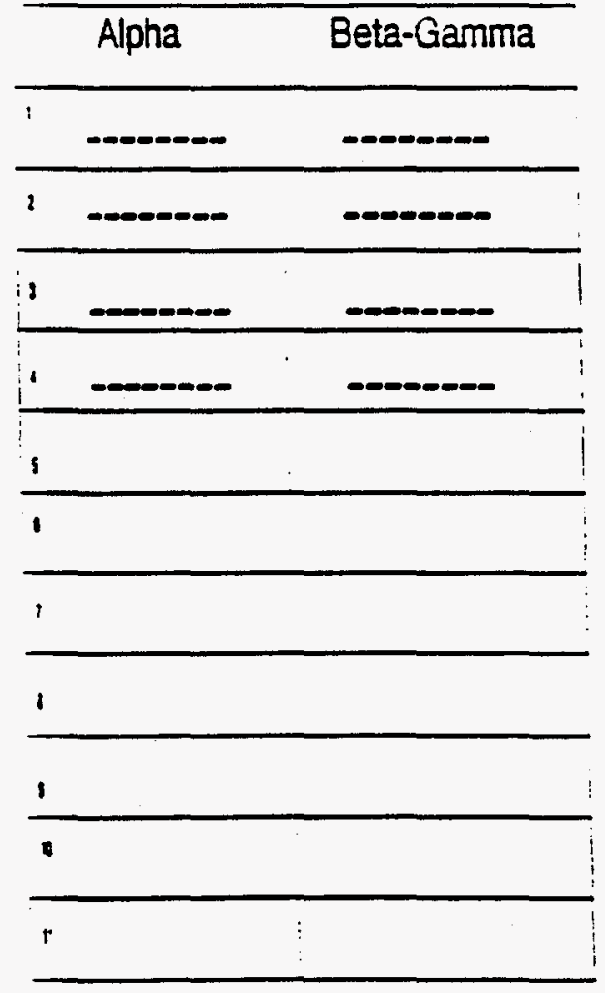

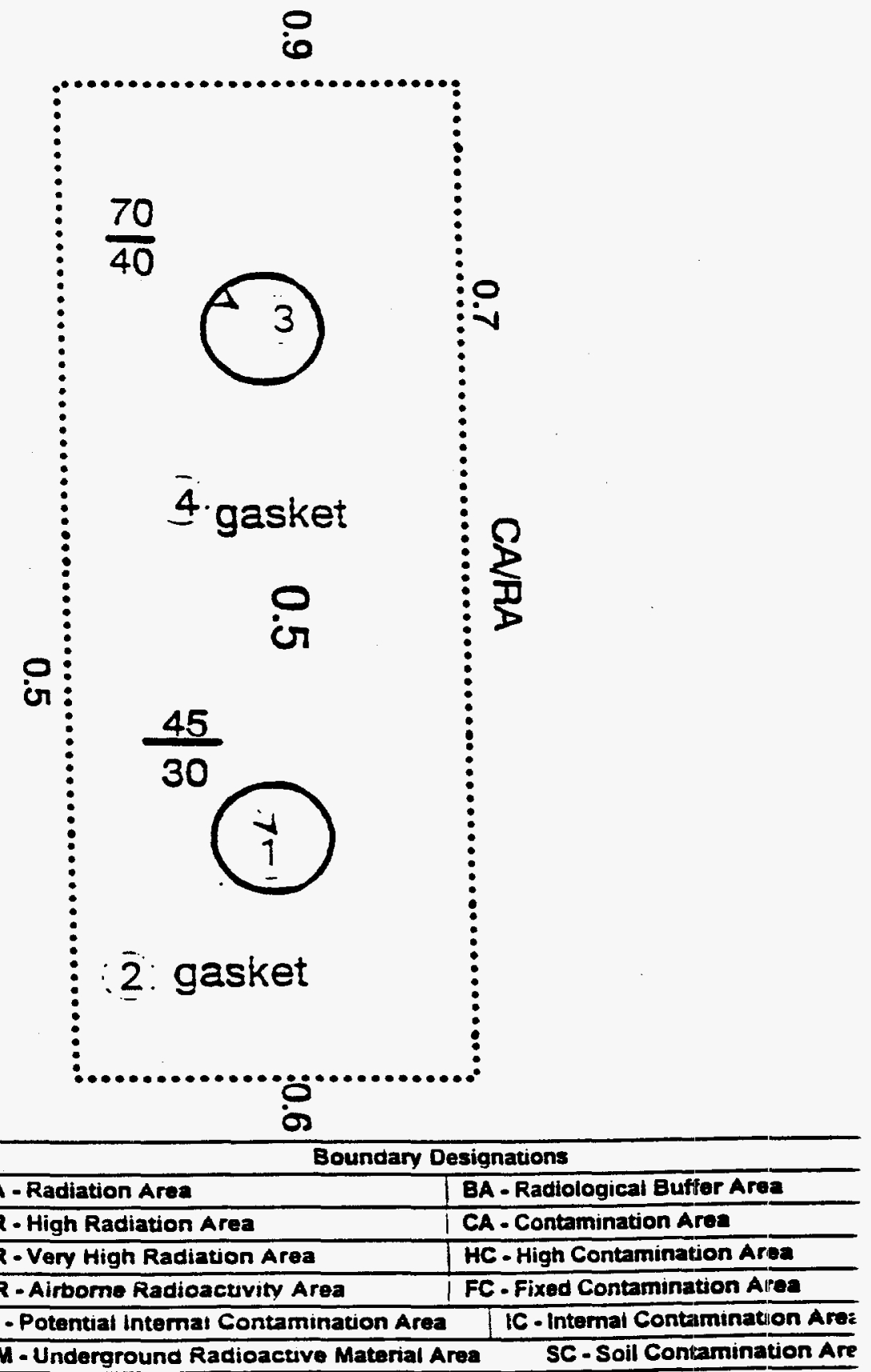

\begin{tabular}{|c|c|c|c|}
\hline (\#) & - Smear Location & \multicolumn{2}{|c|}{ Boundary Designations } \\
\hline$\theta-(\$$ & - Large Area Smear & RA - Radiation Area & BA - Radiological Buffer Area \\
\hline \# & - Contact Dose Rate & HR - High Radiation Area & CA - Contamination Area \\
\hline 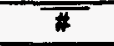 & $.30 \mathrm{~cm}$ Dose Rate & VR - Very High Radiation Area & HC - High Contamination Area \\
\hline$\#$ & - Genoral Area Dose Rate & AR - Airborne Radioactuvity Area & FC.Fixed Contamination Alea \\
\hline SOP! & - Step-oif Pad & P1-Potential intemal Contamination Area & IC - Intemai Contamination Ares \\
\hline AS & - Air Sampie Location & UM - Underground Rad & SC - Soil Contamination Are \\
\hline
\end{tabular}

The default units for dose rates are expressed in dose equivalent as mrem/h. If the dose rates are in units othi than $\mathrm{mrem} / \mathrm{h}$ (e.g., rem/h. umrem/h, etc.), then this shail be noted on the map. Dose rates designated on the st indicate a summation of all the types of radiation detected. uniess the indicated dose rate has a type-icientifie with it (e.g., 2G). The type identifiers are as follows: B - Beta, G - Gamma, N - Neutron. Boundary designation looking from the designations into the zoned area. 


\section{ORNL Radioiogical Survey Data}

\begin{tabular}{|c|c|c|c|}
\hline & Alpha & & Beta-Gamma \\
\hline 1 & & 1 & \\
\hline 2 & & $!$ & 240 \\
\hline 3 & & 1 & \\
\hline 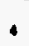 & & $!$ & سمس \\
\hline 3 & & . & 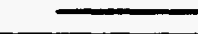 \\
\hline ' & & $!$ & \\
\hline 1 & & ' & - \\
\hline - & & & \\
\hline$\overline{10}$ & & $\vdots$ & \\
\hline$"$ & 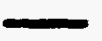 & i & \\
\hline
\end{tabular}

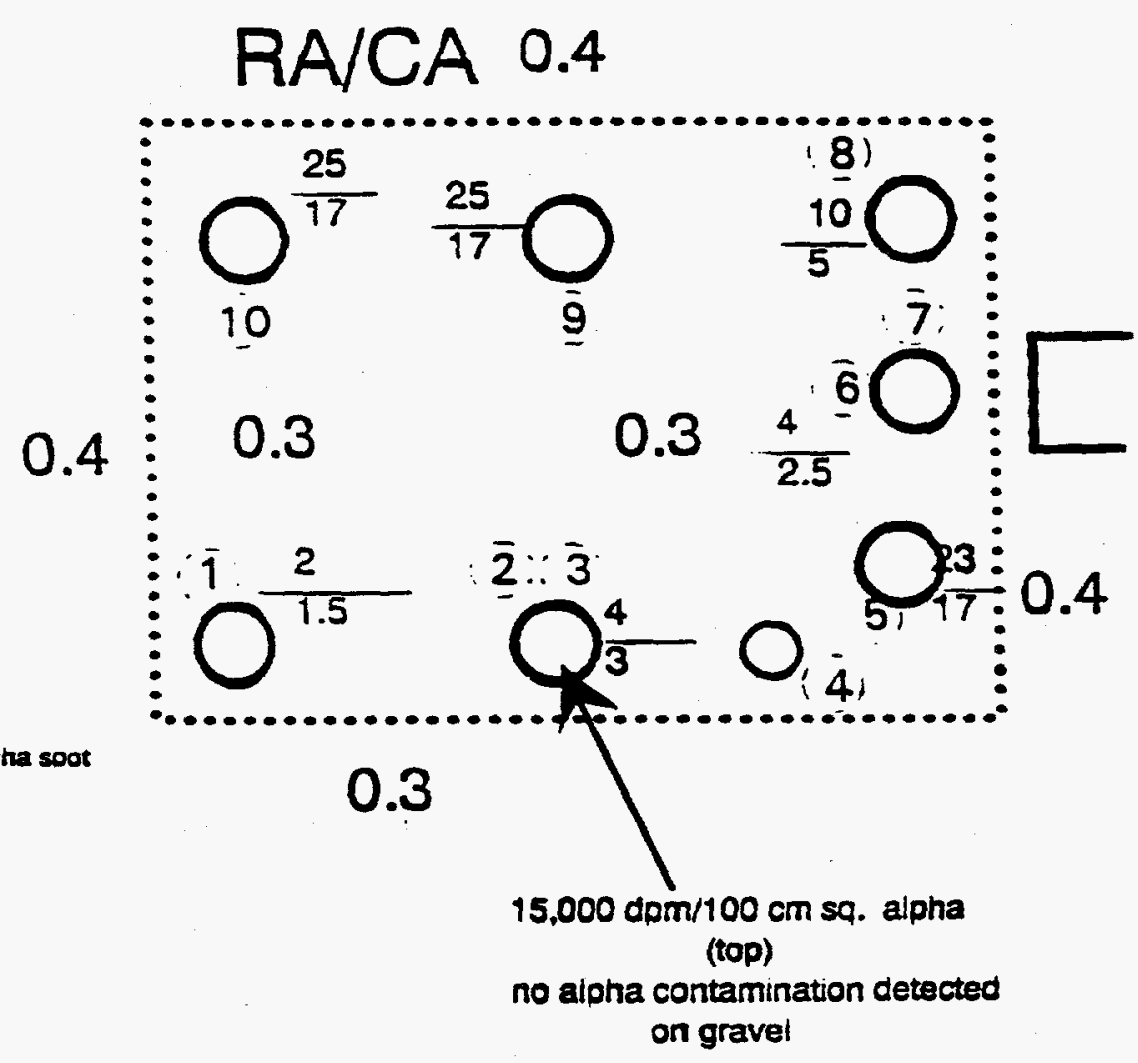

Tank Top readings taken at center and $30 \mathrm{~cm}$ from

\begin{tabular}{|c|c|c|c|}
\hline (\#) & - Smear Location & \multicolumn{2}{|c|}{ Boundary Designations } \\
\hline 丹 & - Large Area Smear & RA - Radiation Area & BA - Radiological Buffer Area \\
\hline$\#$ & - Contact Dose Rate & HR - High Radiation Area & CA - Contamination Area \\
\hline 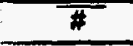 & - $30 \mathrm{~cm}$ Dose Rate & VR - Very High Radiation Area & HC - High Contamination Area \\
\hline$\#$ & - General Area Dose Rate & AR - Airbome Radioactivity Area & FC - Fixed Contamination Area \\
\hline SOP! & - Step-off Pad & P 1- Potential Intemal Contamination Area & IC - Intermal Contamination At \\
\hline AS & - Air Sample Location & \multicolumn{2}{|l|}{ UM - Underground Radioactive Material Area } \\
\hline \multicolumn{4}{|c|}{$\begin{array}{l}\text { The default units for dose rates are expressed in dose equivalent as mrem/h. If the dose rates are in units ol } \\
\text { than mrem/h (e.g., rem/h, umremih, etc.), then this shail be noted on the map. Dose rates designated on the } \\
\text { indicate a summation of all the types of radiation detected, uniess the indicated dose rate has a type-identit } \\
\text { with it (e.g., 2G). The type identifiers are as follows: B - Beta, G - Gamma, N-Neutron. Boundary designati } \\
\text { looking from the designations into the zoned area. }\end{array}$} \\
\hline
\end{tabular}




\section{ORNL Racioiogicai Survey Data}

\section{OHF East Tank Access}

South Tank

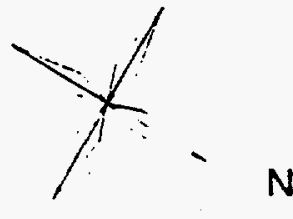

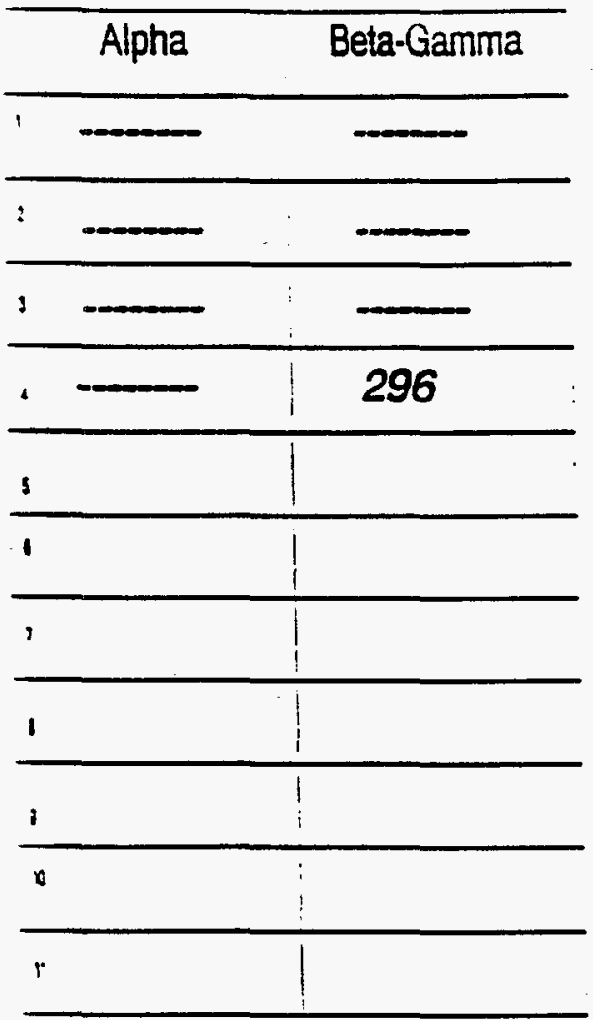

35 at boundary

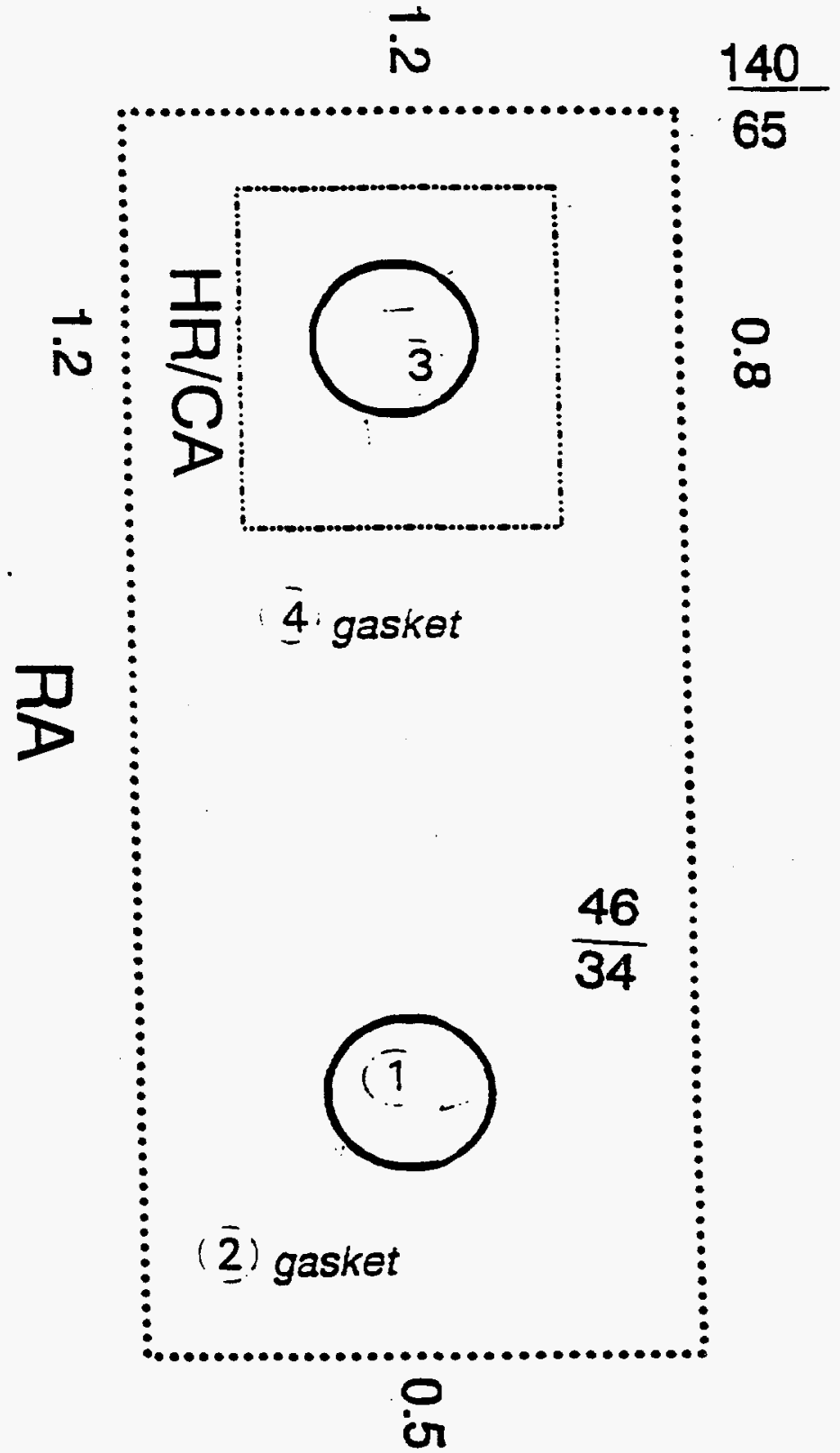

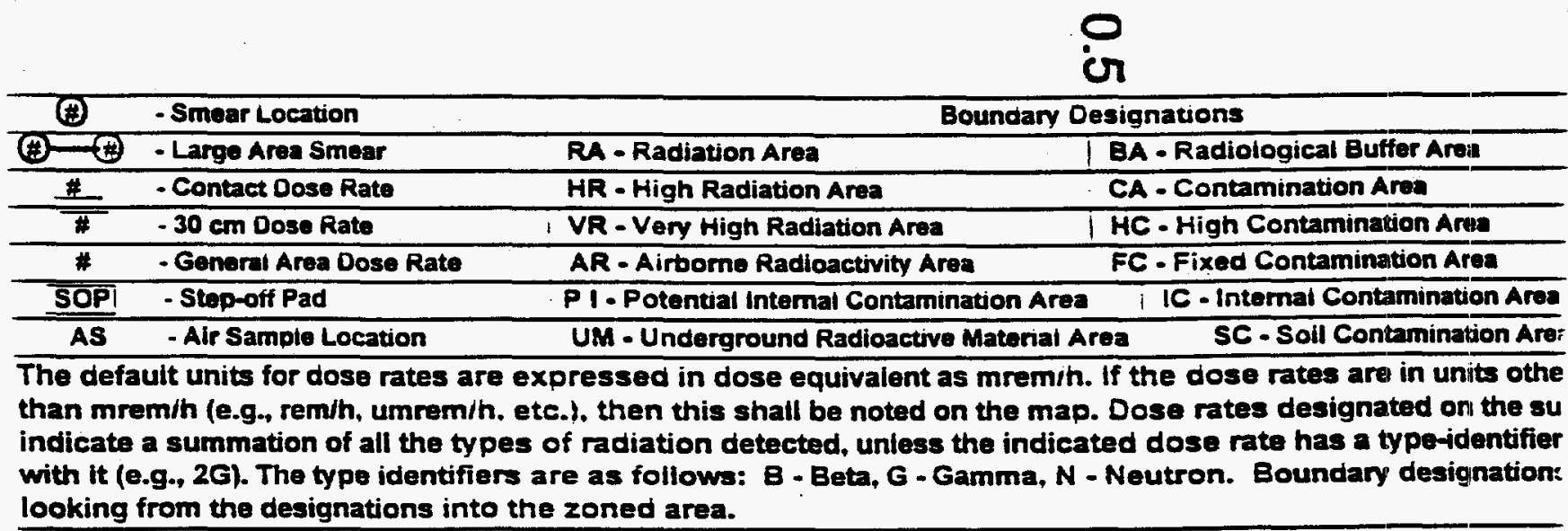




\section{ORNL Radioiogical Survey Data}

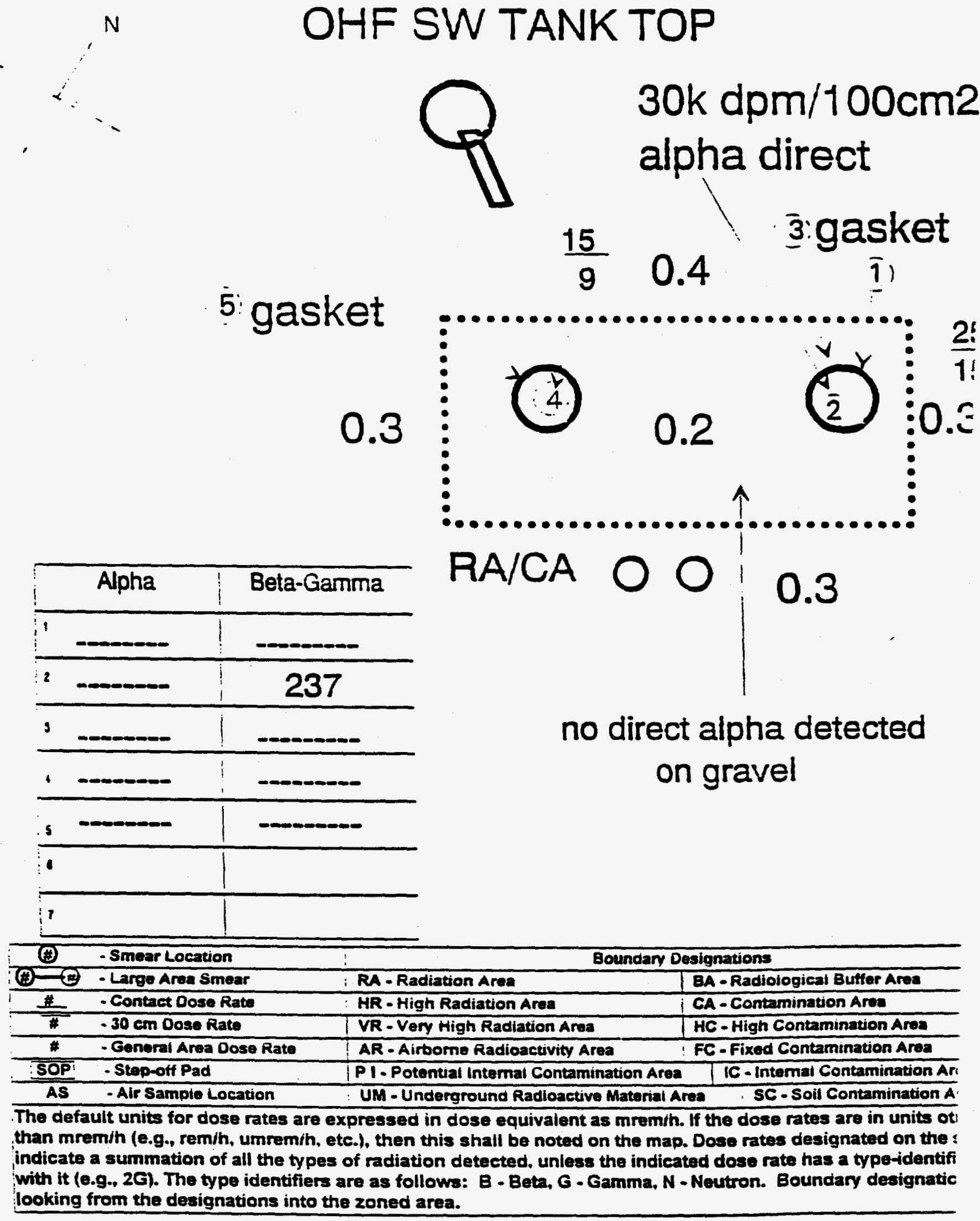




\section{ORNL Radioiogical Survey Data}

N<smiles>CCC(C)(C)C</smiles>

2.5<smiles>C1=CC2=CC=CC2=C1</smiles>

1.3
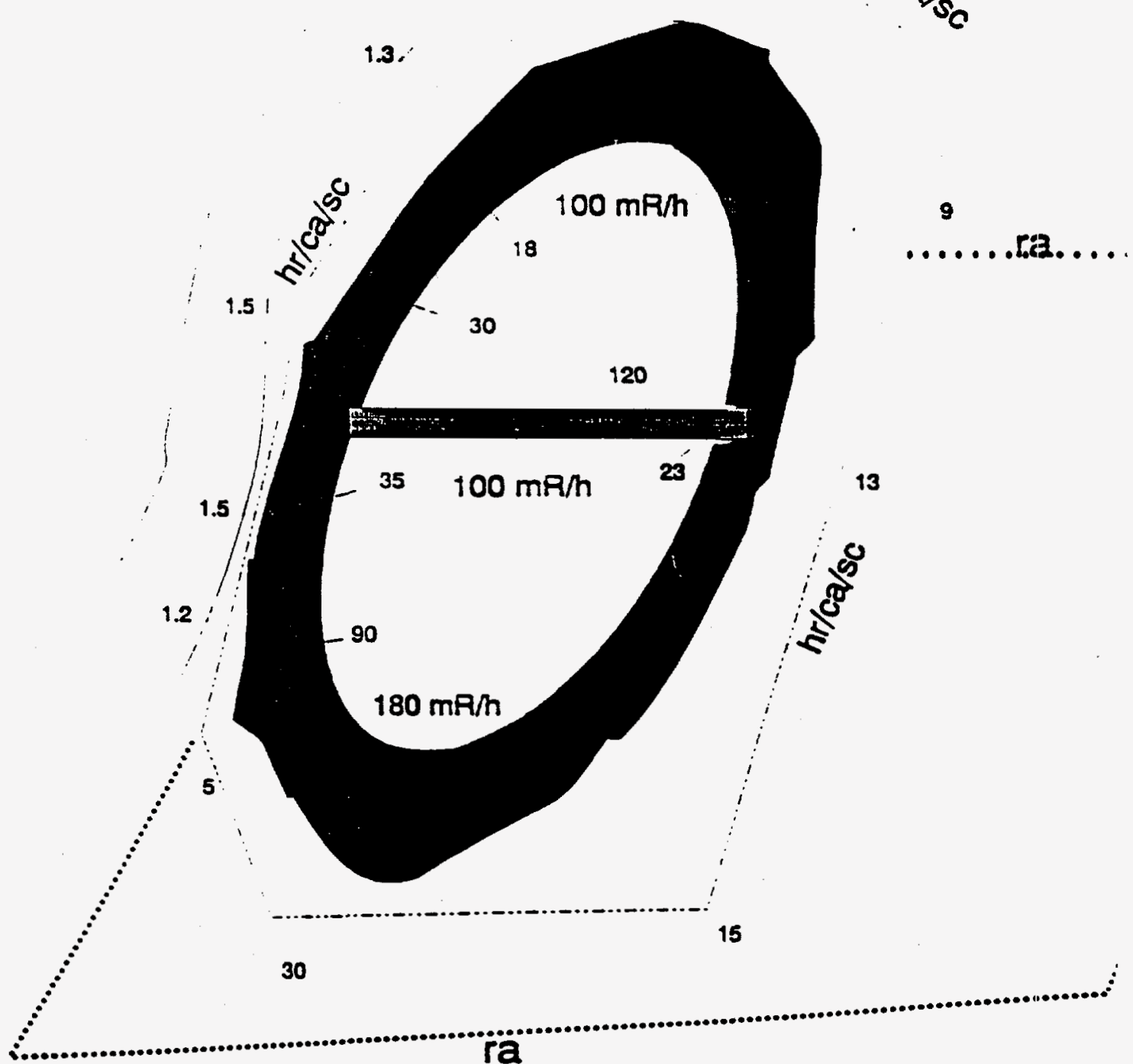

road

\begin{tabular}{|c|c|c|c|}
\hline (\#) & - Smear Locatuon & \multicolumn{2}{|c|}{ Boundary Designations } \\
\hline$\theta-7$ & - Large Area Smear & RA - Radiation Area & BA - Radiological Buffer Area \\
\hline \# & - Contace Dose Rate & HR - High Radiation Area & CA - Contamination Area \\
\hline$\overline{\#}$ & - $30 \mathrm{~cm}$ Dose Rate & VR - Very High Radiation Area & HC - High Contamination Aree \\
\hline$\#$ & - General Area Dose Rate & AR - Airbome Radioactivity Area & FC - Fixed Contamination Area \\
\hline SOPI & - Stop-oit Pad & P 1 - Potential Internal Contamination Area & IC - Intemai Contaminetion Are \\
\hline AS & - Air Sample Location & \multicolumn{2}{|c|}{ UM - Underground Radioactive Material Area $\quad$ SC - Soll Contamination Ar } \\
\hline in & $\begin{array}{l}\text { units for dose rates } \\
\text { in (e.g., rem/h, umren } \\
\text { ummation of all the }\end{array}$ & $\begin{array}{l}\text { essed in dose equival } \\
\text { then this shall be no } \\
\text { radiation detected, un }\end{array}$ & $\begin{array}{l}\text { he dose rates are in units otr } \\
\text { se rates designated on the } 8 \\
\text { dose rate has a type-icientific } \\
\text { utron. Boundary deagnatior }\end{array}$ \\
\hline
\end{tabular}




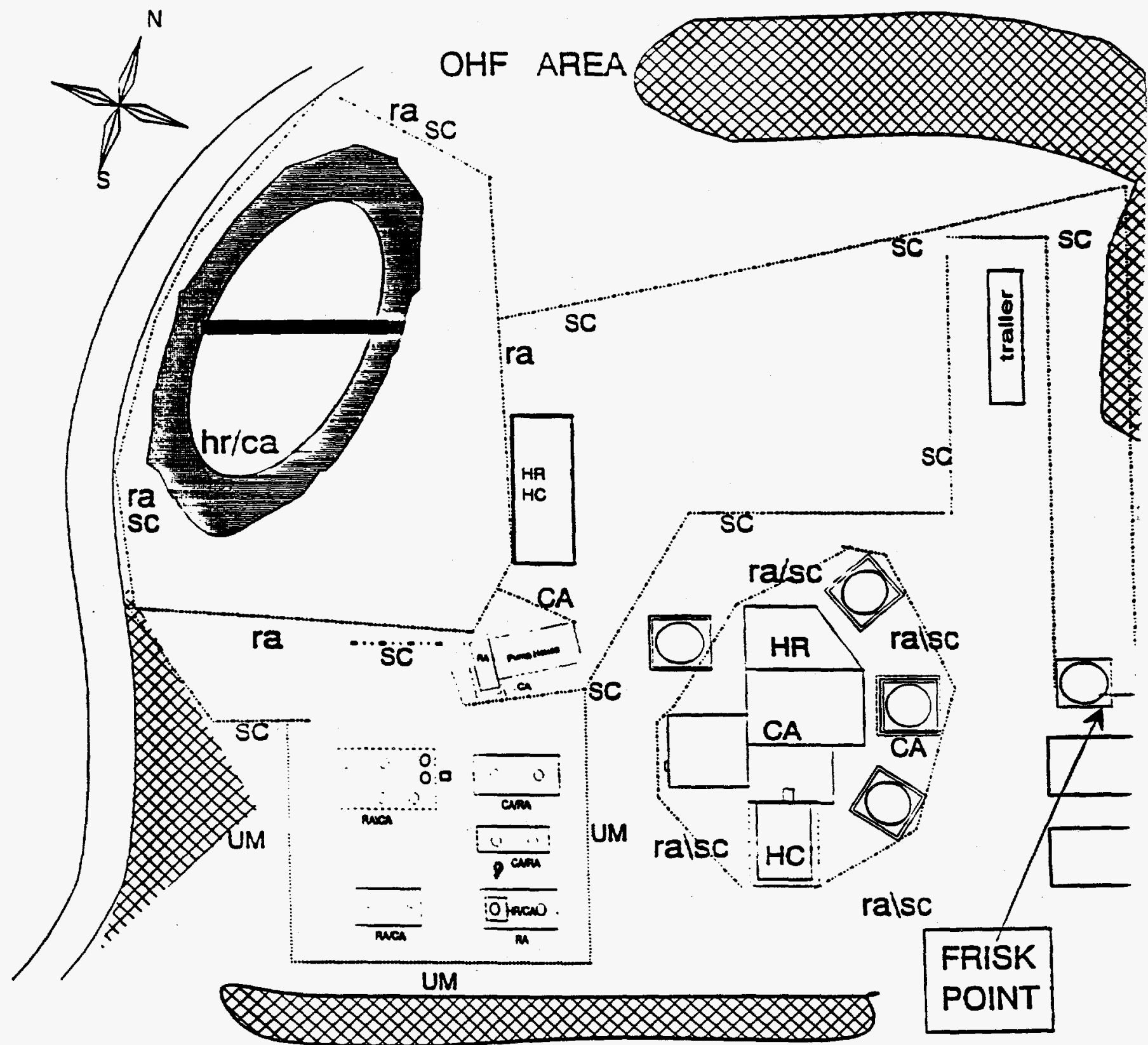

\begin{tabular}{|c|c|c|c|}
\hline$\Theta$ & - Smear Location & \multicolumn{2}{|c|}{ Bounaary Designations } \\
\hline (\$) (20) & - Large Area Smear & RA-Radiation Area & BA - Radiological Buffer Area \\
\hline$\#$ & - Contact Dose Rate & HR - High Radiation Area & CA - Contamination Area \\
\hline \# & $30 \mathrm{~cm}$ Dose Rate & VR - Very High Radiation Area & HC - Migh Contamination Area \\
\hline \# & - General Area Dose Rate & AR - Airbome Radioactivity Area & FC-Fixed Contamination Area \\
\hline SOP. & - Stop-off Pad & PI. Potential Internal Contamination Area & IC . Intermat Contamination Area \\
\hline AS & - Air Sampio Location & UM - Underground Radioactive Matenal Ar & SC - Soil Contamination Area \\
\hline
\end{tabular}

The default units for dose rates are expressed in dose equivalent as mremih. If the dose rates are in units othe than mrem/h (e.g., rem/h, umremih, etc.), then this shall be noted on the map. Dose rates designated on the su indicate a summation of all the types of radiation detected, uniess the indicated dose rate has a type-identifier with it (e.g., 2G). The type identifiers are as follows: B - Beta, G - Gamma, N - Neutron. Boundary designation: looking from the designations into the zoned area. 
ATTACHMENT 2

\section{BASIS FOR PRE-JOB DOSE ESTIMATES}


ALARA Review (Rev 1.0) - Install submersible pumps and riser boxes at OHF January 21, 1998

\begin{tabular}{|c|c|c|c|c|c|c|c|c|c|c|c|}
\hline Tank T-1 north riser & i Personnel & No. & & em/hrs: : & $\sin (n)$ in & 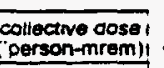 & SHO & RCT & CSF & PF1 & PF2 \\
\hline prepare riser box with pump & CSF,PF1.PF2 & 3 & 1 & 0. & 0.5 & 0 & & & & & \\
\hline hot bolt riser cover & PF1 & 1 & 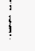 & 17 & 0.25 & 4.25 & & & & 4.3 & \\
\hline vent riser opening & RCT, SHO, PF1 & 3 & 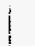 & 17 & 0.05 & 2.55 & 0.9 & 0.9 & & 0.9 & \\
\hline remove \& bag flange cover & PF1,PF2 & 2 & j & 251 & 0.25 & 12.5 & & & & 6.3 & 6.3 \\
\hline remove gasket \& prepare flange lip if & PF1 & 1 & 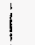 & 25: & $0.25 !$ & 6.25 & & & & 6.3 & \\
\hline place gasket \& allign & CSF.PF1.PF2 & 3 & 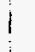 & $25:$ & $0.1:$ & 7.5 & & & 2.5 & 2.5 & 2.5 \\
\hline mount riser spool \& hot bolt & CSF.PF1 & 2 & $i$ & $17^{\prime}$ & 0.1 & 3.4 & & & 1.7 & 1.7 & \\
\hline complete bolt installation & PF1 & 1 & & 17 & 0.25 & 4.25 & & & & 4.3 & \\
\hline subtotal & & & & & & 40.7 & & & & & \\
\hline Tank T-1 south riser & Personnel & No. & & $\begin{array}{l}\text { Se rate } \\
\text { emilhri) }\end{array}$ & ine (mr) 9 & $\begin{array}{l}\text { collective dosei } \\
\text { coerson resmi }\end{array}$ & SHO & RCT & CSF & PF1 & PF2 \\
\hline prepare riser box with pump & CSF.PF1,PF2 & 3 & $i$ & 0 : & 0.5 & 0 & & & & & \\
\hline hot bolt riser cover & PF1 & 1 & : & 9 & 0.25 & 2.25 & & & & 2.3 & \\
\hline vent riser opening & RCT, SHO. PF1 & 3 & $!$ & 9 & 0.05 & 1.35 & 0.5 & 0.5 & & 0.5 & \\
\hline remove \& bag flange cover & PF1,PF2 & 2 & $i$ & $15:$ & 0.25 & 7.5 & & & & 3.8 & 3.8 \\
\hline remove gasket \& prepare flange lip if & PF1 & 1 & 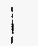 & $15:$ & 0.25 & 3.75 & & & & 3.8 & \\
\hline place gasket \& allign & CSF,PF1,PF2 & 3 & 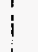 & 15: & 0.1 & 4.5 & & & 1.5 & 1.5 & 1.5 \\
\hline mount riser spool \& hot bolt & CSF.PF1 & 2 & 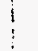 & 9: & 0.1 & 1.8 & & & 0.9 & 0.9 & \\
\hline complete bolt installation & PF1 & 1 & 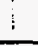 & 9 & 0.25 & 2.25 & & & & 2.3 & \\
\hline subtotal & & & & & & 23.4 & & & & & \\
\hline Tank T-3 north riser & Personnel & No. & & serate: & time (n) & $\begin{array}{l}\text { collective dose) } \\
\text { ('perzon-rem) }\end{array}$ & SHO & RCT & CSF & PF1 & PF2 \\
\hline prepare riser box with pump & CSF,PF1.PF2 & 3 & $i$ & 0 : & 0.5 & 0 & & & & & \\
\hline hot bolt riser cover & PF1 & 1 & 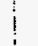 & 40 & 0.25 & 10 & & & & 10 & \\
\hline vent riser opening & RCT, SHO, PF1 & 3 & 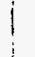 & 40 & 0.05 & 6 & 2 & 2 & & 2 & \\
\hline remove \& bag flange cover & PF1,PF2 & 2 & 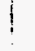 & $70:$ & 0.25 : & 35 & & & & 18 & 18 \\
\hline remove gasket \& prepare flange lip & PF1 & 1 & $i$ & 70 : & 0.25 & 17.5 & & & & 18 & \\
\hline place gasket \& allign & CSF.PF1.PF2 & 3 & : & 70 & 0.1 & 21 & & & 7 & 7 & 7 \\
\hline mount riser spool \& hot bolt & CSF.PF1 & 2 & $i$ & 40. & $0.1:$ & 8 & & & 4 & 4 & \\
\hline complete bolt installation & PF1 & 1 & & $40:$ & 0.25 & 10 & & & & 10 & \\
\hline subtota! & & & & & & 107.5 & & & & & \\
\hline Tank T-3 south riser & Personnel & No. & $d^{d m}$ & $\begin{array}{l}\text { se rate } \\
\text { remu/hi): }\end{array}$ & time (m) i & $\begin{array}{l}\text { collective doses: } \\
\text { ("persen-rem) }\end{array}$ & SHO & RCT & CSF & PF1 & PF2 \\
\hline prepare riser box with pump & CSF.PF1,PF2 & 3 & $\vdots$ & 0 & $0.5:$ & 0 & & & & & \\
\hline hot bolt riser cover & PF1 & 1 & 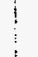 & $65:$ & 0.25 & 16.25 & & & & 16 & \\
\hline vent riser opening & RCT, SHO. PF1 & 3 & $\vdots$ & 65: & 0.05 & 9.75 & 3.3 & 3.3 & & 3.3 & \\
\hline remove \& bag flange cover & PF1,PF2 & 2 & 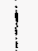 & 140 & $0.25:$ & 70 & & & & 35 & 35 \\
\hline remove gasket \& prepare flange lip & PF1 & 1 & & 140: & 0.25 & 35 & & & & 35 & \\
\hline place gasket \& allign & CSF,PF1,PF2 & 3 & 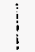 & 140 & $0.1:$ & 42 & & & 14 & 14 & 14 \\
\hline mount riser spool \& hot bolt & CSF.PF1 & 2 & 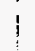 & $65:$ & 0.1 & 13 & & & 6.5 & 6.5 & \\
\hline complete bolt instaliation & PF1 & 1 & : & 65: & $0.25:$ & 16.25 & & & & 16 & \\
\hline sub & & & & & & 202.25 & & & & & \\
\hline
\end{tabular}




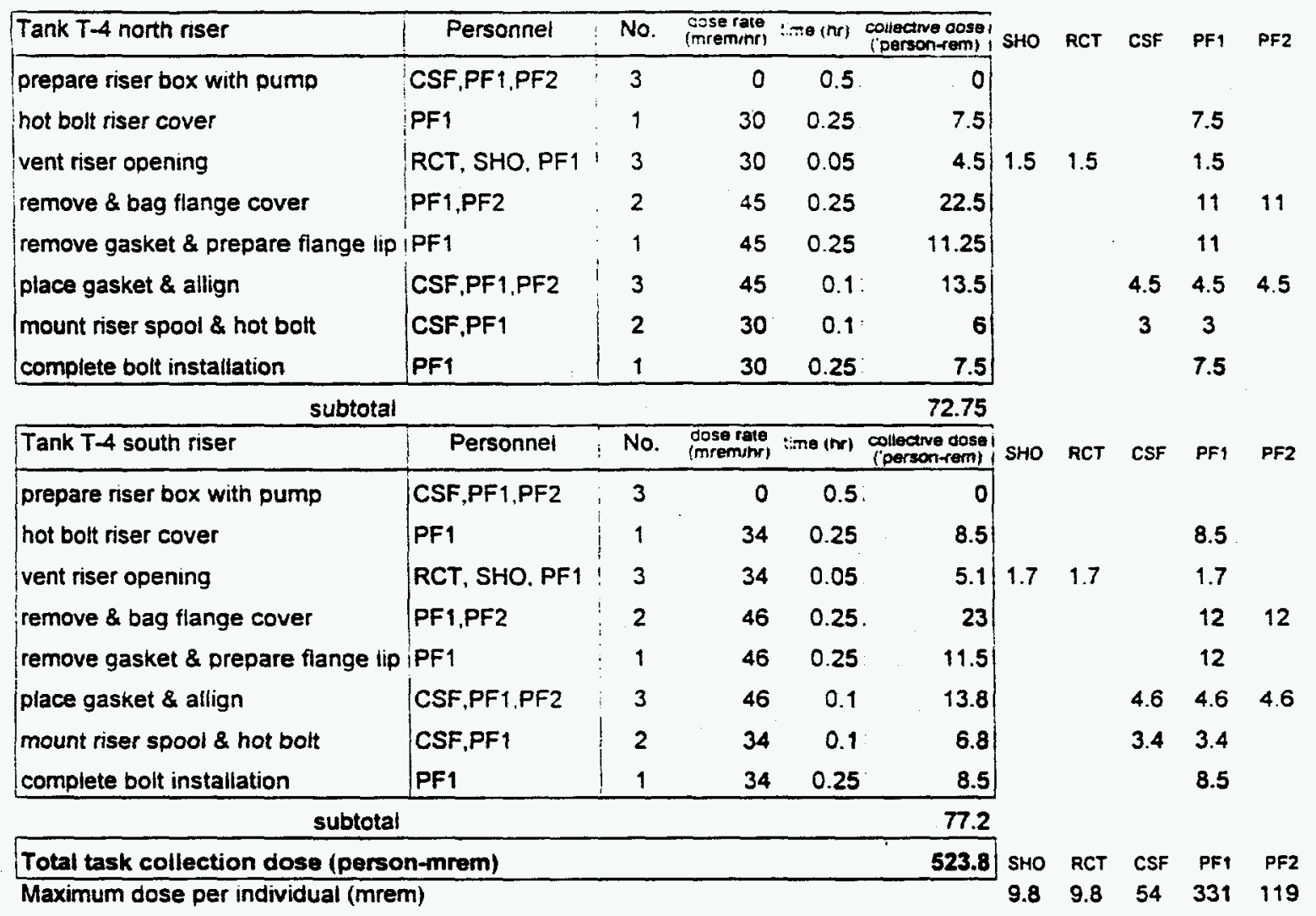


Appendix B

\section{ALARA PLANNING FOR TASKS ASSOCIATED WITH EQUIPMENT INSTALLATION AND MOBILIZATION AND SLUICING AND PUMPING OPERATIONS}




\section{Appendix B \\ ALARA Planning for Tasks Associated with \\ Equipment Installation and Mobilization and Sluicing and Pumping Operations}

This appendix contains the specific ALARA evaluations for the routine tasks that are part of the Equipment Installation and Mobilization as well as Sluicing and Pumping Operations phases. The tasks were selected on the basis for there to be potentially significant radiological exposures. The dose rates were estimated using the recent Radiological Surveillance Section radiological survey: SAAS-97-0635. The work to install the riser spool and submersible pump assemblies on tanks T-1, T-3, and T-4 is not included in this appendix since ALARA planning was accomplished in the ALARA Review contained in Appendix A. Tasks included in this appendix are as follows:

- B-1 - Install Final Riser Assemblies and Mixer

- B-2 - Open Ventilation Connections to Risers

- B-3 - Install Bubbler Tubes

- B-4 - Installing and Removing Tank Cameras

- B-5 - Installing and Removing the Sluicer

Table B.1 lists the personnel that are designated to perform radiological work. Their exposures will be tracked using Siemens electronic pocket dosimeters. However, their official dose record will be generated from their assigned TLDs provided by the Energy Systems external dosimetry program. The Construction Foreman and pipe fitters are generally involved in equipment installation and mobilization, whereas, the operations technicians will perform the work associated with sluicing and pumping operations. The ALARA goal for limiting individual worker exposures is less than 600 mrem maximum total effective dose equivalent.

Table B.1. Key project personnel involved in performing radiological work

\begin{tabular}{|c|c|c|c|c|c|}
\hline Name & $\begin{array}{l}\text { Badge } \\
\text { No. }\end{array}$ & Job Title & Code & Company & $\begin{array}{l}\text { Estimated dose } \\
\text { (mrem) }\end{array}$ \\
\hline Dan Brown & - & $\begin{array}{l}\text { Radiological Control } \\
\text { Technician }\end{array}$ & $\mathrm{RCT}$ & LMER & 43.7 \\
\hline Donnie McCurry & 625985 & Site Safety \& Health Officer & $\mathrm{SHO}$ & CDM Federal & 29.8 \\
\hline Bob Carroll & 701350 & Construction Foreman & CSF & CDM Federal & 68.7 \\
\hline Miguel Naranjo & 701344 & Pipe Fitter \#1 & PF1 & CDM Federal & 499.4 \\
\hline Mike DeBayou & 701347 & Pipe Fitter \#2 & PF2 & CDM Federal & 320.8 \\
\hline Sergio Salcido & 701351 & Operations Technician \#1 & OT1 & CDM Federal & 107.1 \\
\hline Jay Mitchell & 648671 & Operations Technician \#2 & OT2 & CDM Federal & 145.5 \\
\hline Rick Salley & 626213 & Operations Technician \#3 & OT3 & ETE & 3.6 \\
\hline Hypothetical worker & - & Rigger/ Flagman & RG1 & LMER & 3.1 \\
\hline
\end{tabular}


The summary for estimated dose totals for the tasks is listed in Table B.2. The supporting detail for these estimates is included in the spreadsheet calculations included with each task. The ALARA dose estimates for installing the first series of riser spool assemblies and submersible pumps are included in Appendix A.

Table B.2. ALARA dose estimates for tasks associated with equipment installation, mobilization, and sluicing and pumping operations.

\begin{tabular}{|l|c|}
\hline \multicolumn{1}{|c|}{ Task Description } & $\begin{array}{c}\text { Estimated Dose } \\
\text { (mrem) }\end{array}$ \\
\hline Phase I - Install riser spool assemblies and submersible pumps (T-1, T-3, and T-4) & 524 \\
\hline B-1 - Install Final Riser Assemblies and Mixer & 124 \\
\hline B-2 - Open Ventilation Connections to Risers & 210 \\
\hline B-3 - Install Bubbler Tubes & 52 \\
\hline B-4 - Installing and Removing Tank Cameras & 261 \\
\hline B-5 - Installing and Removing the Sluicer & 51 \\
\hline Project Total & 1222 \\
\hline
\end{tabular}




\section{Task B-1. Install Final Riser Assemblies and Mixer}

\section{Task Description}

This task is part of the second phase of field activity for the OHF tanks contents removal campaign. The work involves modifying the tanks by installing riser spools with attached submersible pumps. A total of ten spools are necessary for the campaign. However, this task includes installing the remaining four riser spool/pump combinations in tanks T-2 and T-9. The mixer will be installed in the T-9 center riser. Work Instruction 14, "OHF Riser Spool and Submersible Pump Installation" (ORNL/ER-433, Energy Systems 1998), and Work Instruction 20, "Installing the In-tank Mixer," describe the elements of this task. The key steps for installing a riser spool/submersible pump combination or mixer are as follows:

- Prepare the riser box/spool with submersible pump-The necessary connections between the new riser spool flange and the submersible pumps will be performed in a low background area. All flange openings will be sealed with blind flanges.

- "Hot bolt" riser cover-All bolts on the tank riser flange will be removed except for two or four opposing bolts. Removed bolts will be bagged and stored on-site.

- Perform Heath \& Safety Measurements-The remaining bolts in the tank riser flange cover will be removed, except for one bolt, so that the lid can be shifted to make a 3- or 4-in. opening to test for negative pressure. The excess bolts will be bagged and stored on-site. Measurements include testing for negative pressure (i.e., operating ventilation system) with a smoke tube.

- Remove flange cover-After the remaining bolt in the flange cover is removed, it will be removed and double bagged.

- Remove gasket and prepare flange lip-The tank riser flange lip will be prepared to accept the new riser spool. If necessary, the gasket will be removed and the flange surface scraped with a putty knife to provide a clean, flat surface.

- Place gasket and align new riser spool-The new gasket will be attached to the riser spool flange surface during the preparation step. The submersible pump will be lowered into the tank and the new riser spool will be positioned and aligned using two new bolts to line up the holes. The new riser spool will be set on the tank riser.

- Mount riser spool (or mixer) and "hot bolt"- The new riser spool will be "hot bolted" with at least two opposing bolts and the rigging will be removed.

- Complete bolt installation - The remaining bolts will be installed and tightened. New bolts will be used to install the new riser spool.

\section{Dose Estimates}

The maximum whole body dose expected for this task is as follows: 


\begin{tabular}{|lc|}
\hline \multicolumn{1}{|c|}{ Position } & $\begin{array}{c}\text { Whole body dose } \\
\text { (mrem) }\end{array}$ \\
\hline Construction Foreman (CSF) & 14.7 \\
Pipe Fitter \#1 (PF1) & 36.5 \\
Pipe Fitter \#2 (PF2) & 67.4 \\
SSHO (SHO) & 2.8 \\
Radiological Control Technician (RCT) & 2.8 \\
\hline Total & 124.3 \\
\hline
\end{tabular}

\section{Radiological Hold Points}

\section{Field Measurements}

- Preliminary dose rate measurements at the tank riser-Dose rate measurements will be made at the unopened tank riser before the beginning of work (i.e., loosening bolts). If the dose rate is unexpectedly high (e.g., greater than $20 \%$ over the expected dose rate), further job planning is necessary before beginning work on the tank riser. For example, the ALARA dose estimates will be revised and precautionary steps may be added to reduce personnel exposure.

- Measurements at the vented tank riser-If the dose rate is unexpectedly high (e.g., greater than $20 \%$ over the expected dose rate) when measured at the vented opening, further job planning will be necessary to add precautionary steps to reduce personnel exposure. The SSHO will also verify negative pressure at the opening.

\section{Personnel Exposure}

Workers will use Siemens electronic pocket dosimeters with the alarm set point at 75 mrem cumulative dose and dose rate set point at approximately $20 \%$ over the maximum expected dose rate. Depending on the alarm, the RCT and SSHO will direct the worker to complete the specific step under way when the alarm sounds. If a worker's cumulative dose triggers an alarm, the RCT and SSHO will advise whether work assignments should be shifted between workers before proceeding. An alarm occurring near the end of the job may not result in work assignment adjustments.

\section{Walkdown or Dry Run}

Two identical riser spools (one with submersible pump) were installed at the TTCTF to support the cold test mock-up of the sluicing and pumping system. Six risers were installed during the first phase of equipment installation. The work was covered by the ALARA Review contained in Appendix A. 


\section{Maximum Prefabrication}

The riser spools and submersible pumps will be configured together before being moved into the radiological area. The only work planned in the radiological area is to be the tank riser installation.

\section{Staging Necessary Materials and Tools}

Materials and tools will be staged outside the radiological area. With exception to an air impact wrench for bolt removal, no special tools will be necessary. Duplicate tools and additional nuts and bolts will be on hand.

\section{Radioactive Material Reduction}

Waste materials from the job (e.g., gaskets, nuts, bolts, plastic, PPE, etc.) will be bagged and disposed. Recyclable items, such as rigging and overboots, will be segregated at the step-off pad for survey. No unnecessary items will be introduced into the radiological area.

\section{Engineered Controls}

The OHF tanks have an existing ventilation system connected to the tanks. The operational status of the system will be verified. Plastic will be used around each tank riser to minimize the spread of contamination. If breezy or windy conditions occur, work will be discontinued and the riser openings will be immediately closed (hot bolted).

\section{Special Tooling or Work Processes}

There are no unique work processes or tooling identified to reduce time in the work area. A steel 55-gal drum will be available onsite to provide temporary containment for a contaminated pump if it is necessary to withdraw a pump after it was lowered into the tank contents.

\section{Training}

Workers are required to complete Radiological Worker II training and be respirator qualified.

\section{Temporary Shielding}

No temporary shielding will be used.

\section{Emergency Procedures and Contingency Plans}

The work will be performed under the guidelines in the Site-Specific HASP for the OHF Tanks Contents Removal Project (ORNL/ER-427, Energy Systems 1997c). If an ORNL emergency alarm sounds, the SSHO will ensure that work stops immediately and that all workers are aware of the alarm and are taking the appropriate action. The Field Operations Superintendent will ensure that 
all equipment is secure and shutdown in a safe state. Chapter 7 of the Site-Specific HASP discusses evacuation plans and routes in more detail. The following job-specific contingencies are addressed:

- Damage to a flange surface-A flange surface on either the new riser spool or the tank riser may become damaged during the job due to a crane mishap, etc. The construction foreman will inspect the flange and determine whether a suitable, long-term seal can be maintained after the spool is installed. If the damage to a tank riser flange is significant, the submersible pump should be removed and double-bagged and placed in a steel drum. A flange cover should also be bolted over the riser opening and a layer of plastic should be taped around the top of the covered tank riser to minimize the potential spread of contamination.

- Damage to a gasket-If a gasket is damaged during submersible pump placement, the construction foreman will inspect and repair as required. If it is certain that the submersible pump has not touched the tank contents, it may be withdrawn and the necessary repairs made. Any necessary gasket repairs should be made without withdrawing the pump after it has touched the tank contents.

- Damage to a submersible pump or mixer-If a submersible pump or mixer is damaged during placement, the construction foreman will inspect and decide whether the equipment is capable of operation. No repairs should be attempted at this time if the equipment has touched the tank contents. The damaged equipment should be double bagged and placed in a location determined by the RCT and SSHO.

- Wind and inclement weather-Wind gusts must not exceed $15 \mathrm{mph}$. The SSHO will monitor the wind conditions and periodically contact the Laboratory Shift Superintendent (LSS) for weather updates. The SSHO or RCT will terminate the job if conditions deteriorate in a way that prevents safe work or proper deactivation of the worksite. The SSHO will also decide if wind breaks should be used to reduce the wind effects. 
Install final riser assemblies and mixer

\begin{tabular}{|c|c|c|c|c|c|c|c|c|c|c|}
\hline Tank T-2 north riser & Personnel & No. & $\begin{array}{l}\text { dose rate } \\
\text { (miremhin) }\end{array}$ & time $(\mathrm{hr})$ & $\begin{array}{l}\text { collective dose } \\
\text { (person-mirem) }\end{array}$ & SHO & RCT & CSF & PF1 & PF2 \\
\hline perform H\&S measurements & $\mathrm{RCT}, \mathrm{SHO}$ & 2 & 17 & 0.05 & 1.7 & 0.85 & 0.85 & & & \\
\hline remove $\&$ bag flange cover & PF1.PF2 & 2 & 25 & 0.25 & 12.5 & & & & 6.25 & 6.25 \\
\hline remove gasket \& prepare flange lip & PF2 & 1 & 25 & 0.10 & 2.50 & & & & & 2.50 \\
\hline place gasket \& align & CSF,PF1,PF2 & 3 & 25 & 0.10 & 7.50 & & & 2.50 & 2.50 & 2.50 \\
\hline complete bolt installation & PF2 & 1 & 17 & 0.25 & 4.25 & & & & & 4.25 \\
\hline subtotal & & & & & 36.1 & 0.85 & 0.85 & 4.20 & 10.45 & 19.75 \\
\hline Tank T-2 south riser & Personnel & No. & $\begin{array}{l}\text { dose rate } \\
\text { (mremmn) }\end{array}$ & time (hn) & $\begin{array}{c}\text { collective dose } \\
\text { (person-rem) }\end{array}$ & SHO & RCT & CSF & PF1 & PF2 \\
\hline hot bolt riser cover & PF2 & 1 & 15 & 0.25 & 3.75 & & & & & 3.75 \\
\hline place gasket \& align & CSF,PF $1, P F 2$ & 3 & 25 & 0.10 & 7.50 & & & 2.50 & 2.50 & 2.50 \\
\hline mount riser spool \& hot bolt & CSF.PF1 & 2 & 15 & 0.10 & 3.00 & & & 1.50 & 1.50 & \\
\hline complete bolt installation & PF2 & 1 & 15 & 0.25 & 3.75 & & & & & 3.75 \\
\hline \multicolumn{2}{|l|}{ subtotal } & & & & 34.5 & 0.75 & 0.75 & 4.00 & 10.25 & 18.75 \\
\hline Tank T-9 north riser & Personnel & No. & $\begin{array}{l}\text { dose rate } \\
\text { (mrem/hr) }\end{array}$ & time (hr) & $\begin{array}{c}\text { collective dose } \\
\text { (Derson-rem) }\end{array}$ & SHO & RCT & CSF & PFi & PF2 \\
\hline hot bolt riser cover & PF2 & 1 & 5.0 & 0.25 & 1.25 & & & & & 1.25 \\
\hline perform H\&S measurements & RCT, SHO & 2 & 5.0 & 0.05 & 0.5 & 0.25 & 0.25 & & & \\
\hline remove \& bag flange cover & PF1,PF2 & 2 & 10 & 0.25 & 5.00 & & & & 2.50 & 2.50 \\
\hline hot bolt riser cover & PF2 & 1 & 17 & 0.25 & 4.25 & & & & & 4.25 \\
\hline perform H\&S measurements & RCT, SHO & 2 & 17 & 0.05 & 1.7 & 0.85 & 0.85 & & & \\
\hline remove \& bag flange cover & PF1,PF2 & 2 & 23 & 0.25 & 11.5 & & & & 5.75 & 5.75 \\
\hline remove gasket \& prepare flange lip & $P F 2$ & 1 & 23 & 0.10 & 2.30 & & & & & 2.30 \\
\hline place gasket \& align & CSF,PF1,PF2 & 3 & 23 & 0.10 & 6.90 & & & 2.30 & 2.30 & 2.30 \\
\hline mount riser spool \& hot bolt & CSF,PF1 & 2 & 17 & 0.10 & 3.40 & & & 1.70 & 1.70 & \\
\hline complete boit installation & PF2 & 1 & 17 & 0.25 & 4.25 & & & & & 4.25 \\
\hline \multicolumn{2}{|l|}{ subtotal } & & & & 34.3 & 0.85 & 0.85 & 4.00 & 9.75 & 18.85 \\
\hline Install mixer in Tank T-9 center riser & Personnel & No. & $\begin{array}{l}\text { dose rate } \\
\text { (mrem/nn) }\end{array}$ & time $(\mathrm{hr}$ & $\begin{array}{c}\text { collective dose } \\
\text { (person-rem) }\end{array}$ & SHO & RCT & CSF & PF1 & PF2 \\
\hline hot bolt riser cover & PF2 & 1 & 2.5 & 0.25 & 0.63 & & & & & 0.63 \\
\hline perform H\&S measurements & RCT, SHO & 2 & 2.5 & 0.05 & 0.25 & 0.13 & 0.13 & & & \\
\hline remove $\&$ bag flange cover & PF1,PF2 & 2 & 4.0 & 0.25 & 2.00 & & & & 1.00 & 1.00 \\
\hline remove gasket \& prepare flange lip & PF2 & 1 & 4.0 & 0.10 & 0.40 & & & & & 0.40 \\
\hline place gasket \& align & CSF,PF1,PF2 & 3 & 4.0 & 0.10 & 1.20 & & & 0.40 & 0.40 & 0.40 \\
\hline mount mixer \& hot bolt & CSF.PF1 & 2 & 2.5 & 0.25 & 1.25 & & & 0.63 & 0.63 & \\
\hline complete bolt installation & PF2 & 1 & 2.5 & 0.25 & 0.63 & & & & & 0.63 \\
\hline
\end{tabular}




\section{Task B-2. Open Ventilation Connections to Risers}

\section{Task Description}

This task is part of the equipment installation and mobilization phase of field activity for the OHF tanks contents removal campaign. The work involves making the final connections between the 12-in. PVC ventilation ducts and the riser spools. A connection is made by removing a blind gasket from between flanges, installing a new gasket, and re-connecting the flanges. The key steps for opening the ventilation connections are as follows:

- Remove flange bolts \& blind gasket-The flange bolts will be removed with an air impact wrench and the blind gasket will be slipped out from between the flanges. The blind gasket will be double bagged and disposed as radiological waste. Due to sharp pipe angles, it may not be possible to use an impact wrench for all bolts.

- Install gasket and "hot bolt"- After the new flange is placed between the flanges and aligned, at least two opposing bolts will be installed to secure the connection.

- Complete bolt installation-The remaining bolts will be installed and tightened.

\section{Dose Estimates}

The maximum whole body dose expected for this task is as follows:

\begin{tabular}{|lc|}
\hline \multicolumn{1}{|c|}{ Position } & $\begin{array}{c}\text { Whole body dose } \\
\text { (mrem) }\end{array}$ \\
\hline Pipe Fitter \#1 (PF1) & 97.9 \\
Pipe Fitter \#2 (PF2) & 97.9 \\
Radiological Control Technician (RCT) & 13.9 \\
\hline Total & 209.6 \\
\hline
\end{tabular}

\section{Radiological Hold Points}

\section{Field Measurements}

- Preliminary dose rate measurements at the tank riser-Dose rate measurements will be made before the beginning of work (i.e., loosening bolts). If the dose rate is unexpectedly high (e.g., greater than $20 \%$ over the expected dose rate), further job planning is necessary before beginning work on the tank riser. For example, the ALARA dose estimates will be revised and precautionary steps may be added to reduce personnel exposure. 
Personnel Exposure

Workers will use Siemens electronic pocket dosimeters with the alarm set point at $200 \mathrm{mrem}$ cumulative dose and dose rate set point at approximately $20 \%$ over the maximum expected dose rate. Depending on the alarm, the RCT and SSHO will direct the worker to complete the specific step under way when the alarm sounds. If a worker's cumulative dose triggers an alarm, the RCT and SSHO will advise whether work assignments should be shifted between workers before proceeding. An alarm occurring near the end of the job may not result in work assignment adjustments.

\section{Walkdown or Dry Run}

The original flanges were installed on the riser spools in a low background area. The bolt connections are already in place. The work simply requires that the blind gasket be removed and replaced.

\section{Maximum Prefabrication}

No prefabrication is necessary.

\section{Staging Necessary Materials and Tools}

Staging of materials and tools will be outside the radiological area. With exception of an air impact wrench for bolt removal, no special tools will be necessary. Duplicate tools and additional nuts and bolts will be on hand.

\section{Radioactive Material Reduction}

Waste materials from the job (e.g., gaskets, plastic, PPE, etc.) will be bagged and disposed. Recyclable items, such as overboots, will be segregated at the step-off pad for survey. No unnecessary items will be introduced into the radiological area.

\section{Engineered Controls}

Plastic will be used around each opening to minimize the potential for spreading contamination.

\section{Special Tooling or Work Processes}

There are no unique work processes or tooling identified to reduce time in the work area. An impact wrench will be used when possible to reduce exposure time.

\section{Training}

Workers are required to complete Radiological Worker II training and be respirator qualified. 


\section{Temporary Shielding}

No temporary shielding will be used.

\section{Emergency Procedures and Contingency Plans}

The work will be performed under the guidelines in the Site-Specific HASP for the OHF Tanks Contents Removal Project (ORNL/ER-427, Energy Systems 1997c). If an ORNL emergency alarm sounds, the SSHO will ensure that work stops immediately and that all workers are aware of the alarm and are taking the appropriate action. The Field Operations Superintendent will ensure that all equipment is secure and shutdown in a safe state. Chapter 7 of the Site-Specific HASP discusses evacuation plans and routes in more detail.

- Wind and inclement weather-Wind gusts must not exceed $15 \mathrm{mph}$. The SSHO will monitor the wind conditions and periodically contact the LSS for weather updates. The SSHO or RCT will terminate the job if conditions deteriorate in a way that prevents safe work or proper deactivation of the worksite. The SSHO will also decide if wind breaks should be used to reduce the wind effects. 


\section{Open ventilation connections to risers}

\begin{tabular}{|c|c|c|c|c|c|c|c|c|c|}
\hline Tank T-1 north riser & Personnel & No. & $\begin{array}{l}\text { dose rate } \\
\text { (mrem/hr) }\end{array}$ & time (hr) & $\begin{array}{l}\text { collective dose } \\
\text { (person-mrem) }\end{array}$ & SHO & $\mathrm{RCT}$ & PF1 & PF2 \\
\hline perform rad survey & RCT & 1 & 17 & 0.1 & 1.70 & & 1.70 & & \\
\hline remove flange bolts \& blind gasket & PF1,PF2 & 2 & 17 & 0.2 & 6.80 & & & 3.40 & 3.40 \\
\hline install gasket and hot bolt & PF1,PF2 & 2 & 17 & 0.2 & 6.80 & & & 3.40 & 3.40 \\
\hline complete bolt installation & PF1,PF2 & 2 & 17 & 0.25 & 8.50 & & & 4.25 & 4.25 \\
\hline \multicolumn{3}{|l|}{ subtotal } & & & 23.80 & 0.00 & 1.70 & 11.05 & 11.05 \\
\hline Tank T-2 north riser & Personnel & No. & $\begin{array}{l}\text { dose rate } \\
\text { (mrem/hr) }\end{array}$ & time $(h r)$ & $\begin{array}{c}\text { collective dose } \\
\text { (person-rem) }\end{array}$ & SHO & RCT & PF1 & PF2 \\
\hline perform rad survey & RCT & 1 & 17 & 0.1 & 1.70 & & 1.70 & & \\
\hline remove flange bolts \& blind gasket & PF1,PF2 & 2 & 17 & 0.2 & 6.80 & & & 3.40 & 3.40 \\
\hline install gasket and hot bolt & PF1,PF2 & 2 & 17 & 0.2 & 6.80 & & & 3.40 & 3.40 \\
\hline complete bolt installation & PF1,PF2 & 2 & 17 & 0.25 & 8.50 & & & 4.25 & 4.25 \\
\hline \multicolumn{3}{|l|}{ subtotal } & & & 23.80 & 0.00 & 1.70 & 11.05 & 11.05 \\
\hline Tank T-9 north riser & Personnel & No. & $\begin{array}{l}\text { dose rate } \\
\text { (mrem/hr) }\end{array}$ & time $(\mathrm{hr})$ & $\begin{array}{l}\text { collective dose } \\
\text { (person-rem) }\end{array}$ & SHO & $\mathrm{RCT}$ & PF1 & PF2 \\
\hline perform rad survey & RCT & 1 & 5 & 0.1 & 0.50 & & 0.50 & & \\
\hline remove flange bolts \& blind gasket & PF1,PF2 & 2 & 5 & 0.2 & 2.00 & & & 1.00 & 1.00 \\
\hline install gasket and hot bolt & PF1,PF2 & 2 & 5 & 0.2 & 2.00 & & & 1.00 & 1.00 \\
\hline complete bolt installation & PF1,PF2 & 2 & 5 & 0.25 & 2.50 & & & 1.25 & 1.25 \\
\hline \multicolumn{3}{|l|}{ subtotal } & & & 7.00 & 0.00 & 0.50 & 3.25 & 3.25 \\
\hline Tank T-3 north riser & Personnel & No. & $\begin{array}{l}\text { dose rate } \\
\text { (mrem/hr) }\end{array}$ & time (hr) & $\begin{array}{c}\text { collective dose } \\
\text { (person-rem) }\end{array}$ & SHO & $\mathrm{RCT}$ & PF1 & PF2 \\
\hline perform rad survey & RCT & 1 & 40 & 0.1 & 4.00 & & 4.00 & & \\
\hline remove flange bolts \& blind gasket & PF1,PF2 & 2 & 40 & 0.2 & 16.00 & & & 8.00 & 8.00 \\
\hline install gasket and hot bolt & PF1,PF2 & 2 & 40 & 0.2 & 16.00 & & & 8.00 & 8.00 \\
\hline complete bolt installation & PF1,PF2 & 2 & 40 & 0.25 & 20.00 & & & 10.00 & 10.00 \\
\hline \multicolumn{3}{|l|}{ subtotal } & & & 56.00 & 0.00 & 4.00 & 26.00 & 26.00 \\
\hline Tank T-4 north riser & Personnel & No. & $\begin{array}{l}\text { dose rate } \\
\text { (mrem/hr) }\end{array}$ & time (hr) & $\begin{array}{l}\text { collective dose } \\
\text { (person-rem) }\end{array}$ & SHO & $\mathrm{RCT}$ & PF1 & $\mathrm{PF} 2$ \\
\hline perform rad survey & RCT & 1 & 30 & 0.1 & 3.00 & & 3.00 & & \\
\hline remove flange bolts \& blind gasket & PF1,PF2 & 2 & 30 & 0.2 & 12.00 & & & 6.00 & 6.00 \\
\hline install gasket and hot bolt & PF1,PF2 & 2 & 30 & 0.2 & 12.00 & & & 6.00 & 6.00 \\
\hline complete bolt installation & PF1,PF2 & 2 & 30 & 0.25 & 15.00 & & & 7.50 & 7.50 \\
\hline \multicolumn{3}{|l|}{ subtotal } & & & 42.00 & 0.00 & 3.00 & 19.50 & 19.50 \\
\hline install HEPA Intake at T-4 north & Personnel & No. & $\begin{array}{l}\text { dose rate } \\
\text { (mrem/hr) }\end{array}$ & time (hr) & $\begin{array}{l}\text { collective dose } \\
\text { (person-rem) }\end{array}$ & SHO & RCT & PF1 & PF2 \\
\hline perform rad survey & $\mathrm{RCT}$ & 1 & 30 & 0.1 & 3.00 & & 3.00 & & \\
\hline install HEPA Intake housing & PF1,PF2 & 2 & 15 & 0.5 & 15.00 & & & 7.50 & 7.50 \\
\hline remove flange bolts \& blind gasket & PF1,PF2 & 2 & 30 & 0.2 & 12.00 & & & 6.00 & 6.00 \\
\hline install gasket and hot bolt & PF1,PF2 & 2 & 30 & 0.2 & 12.00 & & & 6.00 & 6.00 \\
\hline complete bolt installation & PF1,PF2 & 2 & 30 & 0.25 & 15.00 & & & 7.50 & 7.50 \\
\hline \multicolumn{3}{|l|}{ subtotal } & & & 57.00 & 0.00 & 3.00 & 27.00 & 27.00 \\
\hline \multicolumn{5}{|c|}{ Total task collective dose (person-mrem) } & 209.6 & & & & \\
\hline \multicolumn{5}{|c|}{ Maximum dose per individual (mrem) } & & 0.0 & 13.9 & 97.9 & 97.9 \\
\hline
\end{tabular}




\section{Task B-3. Install Bubbler Tubes}

\section{Task Description}

This task is part of the equipment installation and mobilization phase of field activity for the OHF tanks contents removal campaign. The work involves installing bubbler tubes in the north riser of each tank to monitor tank liquid levels during operations. The thin stainless steel bubbler tubes are protected by a 1-in. steel exterior pipe that is fastened to the riser spool top. This steel pipe protects the bubbler from being damaged from the sluicer stream. The tubes are installed through a 2 -in. threaded plug on the top of each riser box. The bubbler tube for tank T-1 was installed with the riser spool. The upgraded ventilation system will be operational by the time this task is performed. The key steps for installing the bubbler tubes are as follows:

- Remove 2-in. threaded plug-A pipe wrench will be used to remove the 2-in. plug. Once the plug is removed, the tank will have a small opening to atmospheric air. The ventilation system will be operational before this step is performed. The plug will be double bagged and stored at the OHF site.

- Lower 1-in. pipe and install-A long (approximately 15-ft) pipe will be lowered through the 2 -in. opening in the riser riser box. The top of the pipe will be screwed into the external threaded fitting on the riser box opening where the plug was removed. The work will require the person to use a ladder and lean over the top of the riser while the pipe is lowered in place. The fitting at the top of the pipe prevents the pipe from slipping through the opening and falling into the tank. The pipe must be slowly lowered into the tank such that there will be no sludge disturbance during installation.

- Lower stainless steel bubbler tube and install-A long (approximately $15-\mathrm{ft}$ ) stainless steel bubbler tube will be lowered inside the 1-in. pipe and fastened to the pipe fitting at the top. The work will require the person to use a ladder and lean over the top of the riser while the tube is lowered and fastened in place. The fittings at the top prevent the tube from slipping through the opening and falling into the tank.

\section{Dose Estimates}

\begin{tabular}{|lc|}
\hline \multicolumn{1}{|c|}{ Position } & $\begin{array}{c}\text { Whole body dose } \\
\text { (mrem) }\end{array}$ \\
\hline Pipe Fitter \#1 (PF1) & 20.8 \\
Pipe Fitter \#2 (PF2) & 20.8 \\
SSHO (SHO) & 5.2 \\
Radiological Control Technician (RCT) & 5.2 \\
\hline Total & 52.0 \\
\hline
\end{tabular}


Task B-3, Install Bubbler Tubes

\section{Radiological Hold Points}

\section{Field Measurements}

- Preliminary dose rate measurements at the tank riser-Dose rate measurements will be made before the beginning of work (i.e., loosening the 2 -in. threaded plug). If the dose rate is unexpectedly high (e.g., greater than $20 \%$ over the expected dose rate), further job planning is necessary before beginning work on the tank riser. For example, the ALARA dose estimates will be revised and precautionary steps such as the use of lead blankets may be added to reduce personnel exposure.

\section{Personnel Exposure}

Workers will use Siemens electronic pocket dosimeters with the alarm set point at $20 \mathrm{mrem}$ cumulative dose and dose rate set point at approximately $20 \%$ over the maximum expected dose rate. Depending on the alarm, the RCT and SSHO will direct the worker to complete the specific step under way when the alarm sounds. If a worker's cumulative dose triggers an alarm, the RCT and SSHO will advise whether work assignments should be shifted between workers before proceeding.

\section{Walkdown or Dry Run}

An identical bubbler tube was installed with this method at cold test, whereas, the bubbler tube for tank T-1 was installed in a riser spool before the spool assembly was placed on the tank. The angle of the spool made it necessary for a crane to be used to lift the spool while the tube was installed. The lift was also complicated by the length of pipe protruding from the bottom of the spool. The complications in attaching the tube to the riser before installation are eliminated by this plan to install the tubes after the spools are installed on each tank.

\section{Maximum Prefabrication}

All pipe fittings and connections will be made in a low background area. No work beyond the basic installation is necessary.

\section{Staging Necessary Materials and Tools}

Staging of materials and tools will be outside the radiological area. Duplicate tools will be on hand.

\section{Radioactive Material Reduction}

Waste materials from the job (e.g., gaskets, plastic, PPE, etc.) will be bagged and disposed. Recyclable items, such as overboots, will be segregated at the step-off pad for survey. No unnecessary items will be introduced into the radiological area. 


\section{Engineered Controls}

Plastic will be used around each opening to minimize the potential for spreading contamination. The ventilation system will be operational to ensure negative pressure at the riser opening.

\section{Special Tooling or Work Processes}

There are no unique work processes or tooling identified to reduce time in the work area. A long plastic sleeve should be available onsite in case a mis-threaded pipe needs to be removed and repaired.

\section{Training}

Workers are required to complete Radiological Worker II training and be respirator qualified.

\section{Temporary Shielding}

No temporary shielding will be used. If exposure rates are significantly higher than expected, the RCT may recommend the use of lead blankets at the top of the riser. The Field Operations Superintendent will supervise the placement of shielding to ensure that equipment will not be damaged, etc.

\section{Emergency Procedures and Contingency Plans}

The work will be performed under the guidelines in the Site-Specific HASP for the OHF Tanks Contents Removal Project (ORNL/ER-427, Energy Systems 1997c). If an ORNL emergency alarm sounds, the SSHO will ensure that work stops immediately and that all workers are aware of the alarm and are taking the appropriate action. The Field Operations Superintendent will ensure that all equipment is secure and shutdown in a safe state. Chapter 7 of the Site-Specific HASP discusses evacuation plans and routes in more detail.

- Wind and inclement weather-Wind gusts must not exceed $15 \mathrm{mph}$. The SSHO will monitor the wind conditions and periodically contact the LSS for weather updates. The SSHO or RCT will terminate the job if conditions deteriorate in a way that prevents safe work or proper deactivation of the worksite.

- Misthreaded pipes-If a pipe is misthreaded during installation, it should be removed. Since the length of the pipe is such that it will come in contact with the tank contents, it will be highly contaminated. A long plastic sleeve will be used to bag the pipe as it is withdrawn to minimize the spread of contamination. If appropriate, repairs may be performed on the noncontaminated end of the pipe at a designated laydown area that has the proper radiological postings, etc. 


\section{Install bubbler tubes}

\begin{tabular}{|c|c|c|c|c|c|c|c|c|c|}
\hline Tank T-2 north riser & Personnel & No. & $\begin{array}{c}\text { dose rate } \\
\text { (mrem/hr) }\end{array}$ & time $(\mathrm{hr})$ & $\begin{array}{l}\text { collective dose } \\
\text { (person-mrem) }\end{array}$ & SHO & $\mathrm{RCT}$ & PF9 & PF2 \\
\hline remove 2 -in threaded plug & PF1 & 1 & 17 & 0.1 & 1.70 & & & 1.70 & \\
\hline perform H\&S measurements & SHO,RCT & 2 & 17 & 0.05 & 1.70 & 0.85 & 0.85 & & \\
\hline lower 1 -in pipe \& install & PF2 & 1 & 17 & 0.2 & 3.40 & & & & 3.40 \\
\hline lower stainless bubbler tube $\&$ install & $P F 1$ & 1 & 17 & 0.1 & 1.70 & & & 1.70 & \\
\hline \multicolumn{2}{|l|}{ subtotal } & & & & 8.50 & 0.85 & 0.85 & 3.40 & 3.40 \\
\hline Tank T-3 north riser & Personnel & No. & $\begin{array}{l}\text { dose rate } \\
\text { (mrem/hr) }\end{array}$ & time (hr) & $\begin{array}{c}\text { collective dose } \\
\text { (person-rem) }\end{array}$ & SHO & RCT & PF1 & PF2 \\
\hline remove 2-in threaded plug & PF1 & 1 & 40 & 0.1 & 4.00 & & & 4.00 & \\
\hline perform H\&S measurements & SHO,RCT & 2 & 40 & 0.05 & 4.00 & 2.00 & 2.00 & & \\
\hline lower 1 -in pipe $\&$ install & PF2 & 1 & 40 & 0.2 & 8.00 & & & & 8.00 \\
\hline lower stainless bubbler tube $\&$ install & PF1 & 1 & 40 & 0.1 & 4.00 & & & 4.00 & \\
\hline \multicolumn{2}{|l|}{ subtotal } & & & & 20.00 & 2.00 & 2.00 & 8.00 & 8.00 \\
\hline Tank T-4 north riser & Personnel & No. & $\begin{array}{l}\text { dose rate } \\
\text { (mrem/hr) }\end{array}$ & time (hr) & $\begin{array}{l}\text { collective dose } \\
\text { (person-rem) }\end{array}$ & SHO & RCT & PF1 & PF2 \\
\hline remove 2 -in threaded plug & PF1 & 1 & 30 & 0.1 & 3.00 & & & 3.00 & \\
\hline perform H\&S measurements & SHO,RCT & 2 & 30 & 0.05 & 3.00 & 1.50 & 1.50 & & \\
\hline lower 1 -in pipe $\&$ install & PF2 & 1 & 30 & 0.2 & 6.00 & & & & 6.00 \\
\hline lower stainless bubbler tube $\&$ install & PF1 & 1 & 30 & 0.1 & 3.00 & & & 3.00 & \\
\hline \multicolumn{2}{|l|}{ subtotal } & & & & 15.00 & 1.50 & 1.50 & 6.00 & 6.00 \\
\hline Tank T-9 south riser & Personnel & No. & $\begin{array}{l}\text { dose rate } \\
\text { (mrem/hr) }\end{array}$ & time (hr) & $\begin{array}{l}\text { collective dose } \\
\text { (person-rem) }\end{array}$ & SHO & $\mathrm{RCT}$ & PF1 & PF2 \\
\hline remove 2-in threaded plug & PF1 & 1 & 17 & 0.1 & 1.70 & & & 1.70 & \\
\hline perform H\&S measurements & SHO,RCT & 2 & 17 & 0.05 & 1.70 & 0.85 & 0.85 & & \\
\hline lower 1 -in pipe \& install & PF2 & 1 & 17 & 0.2 & 3.40 & & & & 3.40 \\
\hline lower stainless bubbler tube $\&$ install & PF1 & 1 & 17 & 0.1 & 1.70 & & & 1.70 & \\
\hline \multicolumn{2}{|l|}{ subtotal } & & & & 8.50 & 0.85 & 0.85 & 3.40 & 3.40 \\
\hline \multicolumn{2}{|c|}{ Total task collective dose (person-mrem) } & & & & 52.0 & & & & \\
\hline \multicolumn{2}{|l|}{ Maximum dose per individual (mrem) } & & & & & 5.2 & 5.2 & 20.8 & 20.8 \\
\hline
\end{tabular}




\section{Task B-4. Installing and Removing Tank Cameras}

\section{Task Description}

Although the first tank cameras will be installed as part of the equipment installation and mobilization phase, this task is part of the sluicing and pumping phase of field activity for the OHF tanks contents removal campaign. Tank cameras are necessary to monitor the withdrawal of supernate for transfer between tanks, to observe the progress of sluicing operations, and to monitor the mixing tank T-9. The cameras are installed at the end of an inverted steel post attached to 8 -in. flanges. They are mounted to a flange connection at the top of the riser spool assemblies at the north ends of the subject tanks and south end of the mixing tank. This task is described in detail in Work Instruction 13, "Installing and Moving In-tank Camera," (ORNL/ER-433, Energy Systems 1998).

Although a crane will be used to support camera relocation, a block and tackle will be used to permit manual lifting and positioning. It is important to carefully guide the camera as it is raised and lowered to prevent damage from the sides of the riser, etc. A custom plastic sleeve has been developed to provide contamination control when cameras are withdrawn from a tank. The upgraded ventilation system will be operational by the time this task is performed. The key steps for installing and removing the cameras are as follows:

- Remove 8-in. blind flange and gasket-Plastic sheeting should first be placed around the opening. An impact wrench will be used to remove the 8-in. blind flange. Once the flange plate is removed, the tank will have a small opening to atmospheric air. It is necessary for the ventilation system to be operational for this task to be authorized. The blind flange will be double bagged and stored at the OHF site. The gasket will remain on the flange if there is no visible damage.

- Place gasket, lower and align camera - Once the gasket is placed, the camera is lowered in place. The camera will be supported by a block and tackle connected to a crane hook positioned over the riser. The end of the plastic sleeve extending from the lower end of the camera post is first connected to the flange top. As the camera is lowered, the plastic sleeve is gathered in a roll around the flange. When the camera is positioned, the top of the sleeve is loosened to expose the bolt holes.

- Complete bolt installation-At least four bolts should be tightened to prevent leakage around the gasket while the camera is in place.

- Remove bolts, install rigging, and withdraw camera-After the bolts are removed, the block and tackle is attached to the eye bolts on top of the camera flange. The plastic sleeve is pulled over the top flange and secured. As the camera is withdrawn, the plastic sleeve slides up and around the camera post. The hoist operator must exercise great caution to ensure that the camera does not catch on the tank riser edges during lifting. Once the camera is raised above the surface of the flange top, it is moved to the side and the plastic sleeve tied off to prevent residual contamination leaks. 
- Install 8-in. blind flange-At least four bolts will be used to secure the blind flange. The gasket will be reused if there is no visible damage. Any plastic used for contamination control will also be removed and disposed.

\section{Dose Estimates}

\begin{tabular}{|lc|}
\multicolumn{1}{|c|}{ Position } & $\begin{array}{c}\text { Whole body dose } \\
\text { (mrem) }\end{array}$ \\
\hline Pipe Fitter \#1 (PF1) & 6.0 \\
Pipe Fitter \#2 (PF2) & 8.5 \\
Operations Technician \#1 (OT1) & 93.3 \\
Operations Technician \#2 (OT2) & 132.5 \\
SSHO (SHO) & 10.4 \\
Radiological Control Technician (RCT) & 10.4 \\
\hline Total & 261.1 \\
\hline
\end{tabular}

\section{Radiological Hold Points}

\section{Field Measurements}

- Preliminary dose rate measurements at the tank riser-Dose rate measurements will be made before the beginning of work (i.e., loosening the bolts). If the dose rate is unexpectedly high (e.g., greater than $20 \%$ over the expected dose rate), further job planning is necessary before beginning work on the tank riser. For example, the ALARA dose estimates will be revised and precautionary steps such as the use of lead blankets may be added to reduce personnel exposure.

\section{Personnel Exposure}

Workers will use Siemens electronic pocket dosimeters with the alarm set point at $135 \mathrm{mrem}$ cumulative dose and dose rate set point at approximately $20 \%$ over the maximum expected dose rate. Depending on the alarm, the RCT and SSHO will direct the worker to complete the specific step under way when the alarm sounds. If a worker's cumulative dose triggers an alarm, the RCT and SSHO will advise whether work assignments should be shifted between workers before proceeding.

\section{Walkdown or Dry Run}

Cameras have been installed at the cold test facility. Installation and withdrawal have been rehearsed and refined in noncontaminated environments. Work Instruction 13 was developed using the cold test dry runs. 


\section{Maximum Prefabrication}

No work beyond the basic installation or removal is necessary.

\section{Staging Necessary Materials and Tools}

Materials and tools will be staged outside the radiological area. Duplicate tools will be on hand.

\section{Radioactive Material Reduction}

Waste materials from the job (e.g., gaskets, plastic, PPE, etc.) will be bagged and disposed. Recyclable items, such as overboots, will be segregated at the step-off pad for survey. No unnecessary items will be introduced into the radiological area.

\section{Engineered Controls}

Plastic will be used around each opening to minimize the potential for spreading contamination. The ventilation system will be operational to ensure negative pressure at the riser opening.

\section{Special Tooling or Work Processes}

A block and tackle will be used to hoist the camera. The camera hoisting equipment and rigging should be inspected before each use. Push rods will also be used to help guide the camera post without using hands or fingers. A reusable plastic sleeve will be wrapped around the camera to provide contamination control while the camera is transferred between tanks.

\section{Training}

Workers are required to complete Radiological Worker II training and be respirator qualified. The operations technicians will be trained on Work Instruction 13, "Installing and Moving In-Tank Camera."

\section{Temporary Shielding}

No temporary shielding will be used. If exposure rates are significantly higher than expected, the RCT may recommend the use of lead blankets at the top of the riser. The Field Operations Superintendent will supervise the placement of shielding to ensure that equipment will not be damaged, etc.

\section{Emergency Procedures and Contingency Plans}

The work will be performed under the guidelines in the Site-Specific HASP for the OHF Tanks Contents Removal Project (ORNL/ER-427, Energy Systems 1997c). If an ORNL emergency alarm sounds, the SSHO will ensure that work stops immediately and that all workers are aware of the alarm and are taking the appropriate action. The Field Operations Superintendent will ensure that 
all equipment is secure and shutdown in a safe state. Chapter 7 of the Site-Specific HASP discusses evacuation plans and routes in more detail.

- Wind and inclement weather-Wind gusts must not exceed $15 \mathrm{mph}$. The SSHO will monitor the wind conditions and periodically contact the LSS for weather updates. The SSHO or RCT will terminate the job if conditions deteriorate in a way that prevents safe work or proper deactivation of the worksite.

- Broken or lost camera-If a camera breaks away from the post during lifting, there should be no attempt for retrieval until the tanks contents have been removed. A separate ALARA evaluation will be necessary to support camera extraction efforts.

- Repairing a broken camera - If a camera is damaged and requires repair, the bagged camera arrangement is removed and placed in a designated lay-down area. The camera head, mounting post, and flange will be highly contaminated once removed from a tank. If appropriate, the camera should be removed from the post and decontaminated before repairs are attempted. The removed camera may be serviced inside a glove box if available. 
Installing and removing cameras

\begin{tabular}{|c|c|c|c|c|c|c|c|c|c|c|c|}
\hline install camera in T-9 mixing tank & Personnel & No. & $\begin{array}{l}\text { dose rate } \\
\text { (mremihr) }\end{array}$ & time $(\mathrm{hr})$ & $\begin{array}{l}\text { collective dose } \\
\text { (person-mrem) }\end{array}$ & SHO & RCT & PF1 & PF2 & Or1 & OT2 \\
\hline remove 8 -in blind flange \& gasket & PF1 & 1 & 17 & 0.10 & 1.70 & & & 1.70 & & & \\
\hline perform H\&S measurements & SHO,RCT & 2 . & 17 & 0.05 & 1.70 & 0.85 & 0.85 & & & & \\
\hline place gasket \& align camera flange holes & PF1,PF2 & 2 & 17 & 0.25 & 8.50 & & & 4.25 & 4.25 & & \\
\hline complete bolt installation for camera & PF2 & 1 & 17 & 0.25 & 4.25 & & & & 4.25 & & \\
\hline remove bolts \& withdraw camera & OT1,OT2 & 2 & 17 & 0.25 & 8.50 & & & & & 4.25 & 4.25 \\
\hline replace 8 -in blind flange & OT2 & 1 & 17 & 0.10 & 1.70 & & & & & & 1.70 \\
\hline \multicolumn{3}{|l|}{ subtotal } & & & 26.35 & 0.85 & 0.85 & 5.95 & 8.50 & 4.25 & 5.95 \\
\hline install in $T-1$ to support supernate $x$-fer to $T-3$ & Personnel & No. & $\begin{array}{l}\text { dose rate } \\
\text { (mrem/hr) }\end{array}$ & time $(\mathrm{hr})$ & $\begin{array}{l}\text { collective dose } \\
\text { (person-rem) }\end{array}$ & SHO & RCT & PF1 & PF2 & OT 1 & OT2 \\
\hline remove 8 -in blind flange \& gasket & OT1 & 1 & 17 & 0.10 & 1.70 & & & & & 1.70 & \\
\hline perform H\&S measurements & SHO,RCT & 2 & 17 & 0.05 & 1.70 & 0.85 & 0.85 & & & & \\
\hline place gasket \& align camera flange holes & OT1, OT2 & 2 & 17 & 0.25 & 8.50 & & & & & 4.25 & 4.25 \\
\hline complete bolt installation for camera & OT2 & 1 & 17 & 0.25 & 4.25 & & & & & & 4.25 \\
\hline remove bolts \& withdraw camera & OT1, OT2 & 2 & 17 & 0.25 & 8.50 & & & & & 4.25 & 4.25 \\
\hline replace 8 -in blind flange & OT2 & 1 & 17 & 0.10 & 1.70 & & & & & & 1.70 \\
\hline \multicolumn{3}{|l|}{ subtotal } & & & 26.35 & 0.85 & 0.85 & 0.00 & 0.00 & 10.20 & 14.45 \\
\hline install in $T-2$ to support supernate $x$-fer to $T-3$ & Personnel & No. & $\begin{array}{l}\text { dose rate } \\
\text { (mremihr) }\end{array}$ & time (hr) & $\begin{array}{l}\text { collective dose } \\
\text { (person-rem) }\end{array}$ & SHO & $\mathrm{RCT}$ & PF1 & $\mathrm{PF} 2$ & OT1 & OT2 \\
\hline remove 8 -in blind flange $\&$ gasket & OT1 & 1 & 17 & 0.10 & 1.70 & & & & & 1.70 & \\
\hline perform H\&S measurements & SHO,RCT & 2 & 17 & 0.05 & 1.70 & 0.85 & 0.85 & & & & \\
\hline place gasket \& align camera flange holes & OT1,OT2 & 2 & 17 & 0.25 & 8.50 & & & & & 4.25 & 4.25 \\
\hline complete bolt installation for camera & OT2 & 1 & 17 & 0.25 & 4.25 & & & & & & 4.25 \\
\hline remove bolts \& withdraw camera & OT1,OT2 & 2 & 17 & 0.25 & 8.50 & & & & & 4.25 & 4.25 \\
\hline replace 8 -in blind flange & OT2 & 1 & 17 & 0.10 & 1.70 & & & & & & 1.70 \\
\hline \multicolumn{3}{|l|}{ subtotal } & & & 26.35 & 0.85 & 0.85 & 0.00 & 0.00 & 10.20 & 14.45 \\
\hline install in $T-3$ to support sluicing & Personnel & No. & $\begin{array}{l}\text { dose rate } \\
(\mathrm{mrem} / \mathrm{hr})\end{array}$ & time (hr) & $\begin{array}{c}\text { collective dose } \\
\text { (person-rem) }\end{array}$ & SHO & $\mathrm{RCT}$ & PF1 & PF2 & OT1 & OT2 \\
\hline remove 8 -in blind flange $\&$ gasket & OT1 & 1 & 40 & 0.10 & 4.00 & & & & & 4.00 & \\
\hline perform H\&S measurements & SHO,RCT & 2 & 40 & 0.05 & 4.00 & 2.00 & 2.00 & & & & \\
\hline place gasket $\&$ align camera flange holes & OT1,OT2 & 2 & 40 & 0.25 & 20.00 & & & & & 10.00 & 10.00 \\
\hline complete bolt installation for camera & OT2 & 1 & 40 & 0.25 & 10.00 & & & & & & 10.00 \\
\hline remove bolts \& withdraw camera & OT1, OT2 & 2 & 2 & 0.25 & 1.00 & & & & & 0.50 & 0.50 \\
\hline replace 8 -in blind flange & OT2 & 1 & 2 & 0.10 & 0.20 & & & & & & 0.20 \\
\hline \multicolumn{3}{|l|}{ subtotal } & & & 39.20 & 2.00 & 2.00 & 0.00 & 0.00 & 14.50 & 20.70 \\
\hline install in $T-2$ to $x$-fer reserve supernate to $T-3$ & Personnel & No. & $\begin{array}{l}\text { dose rate } \\
(\mathrm{mrem} / \mathrm{hr})\end{array}$ & time (hr) & $\begin{array}{c}\text { collective dose } \\
\text { (person-rem) }\end{array}$ & SHO & $\mathrm{RCT}$ & PF1 & PF2 & OT1 & OT2 \\
\hline remove 8 -in blind flange \& gasket & OT1 & 1 & 17 & 0.10 & 1.70 & & & & & 1.70 & \\
\hline perform H\&S measurements & SHO,RCT & 2 & 17 & 0.05 & 1.70 & 0.85 & 0.85 & & & & \\
\hline place gasket $\&$ align camera flange holes & OT1, OT2 & 2 & 17 & 0.25 & 8.50 & & & & & 4.25 & 4.25 \\
\hline complete bolt installation for camera & OT2 & 1 & 17 & 0.25 & 4.25 & & & & & & 4.25 \\
\hline remove bolts \& withdraw camera & OT1,OT2 & 2 & 17 & 0.25 & 8.50 & & & & & 4.25 & 4.25 \\
\hline replace 8 -in blind flange & OT2 & 1 & 17 & 0.10 & 1.70 & & & & & & 1.70 \\
\hline \multicolumn{3}{|l|}{ subtotal } & & & 26.35 & 0.85 & 0.85 & 0.00 & 0.00 & 10.20 & 14.45 \\
\hline
\end{tabular}




\section{Installing and removing cameras (continued)}

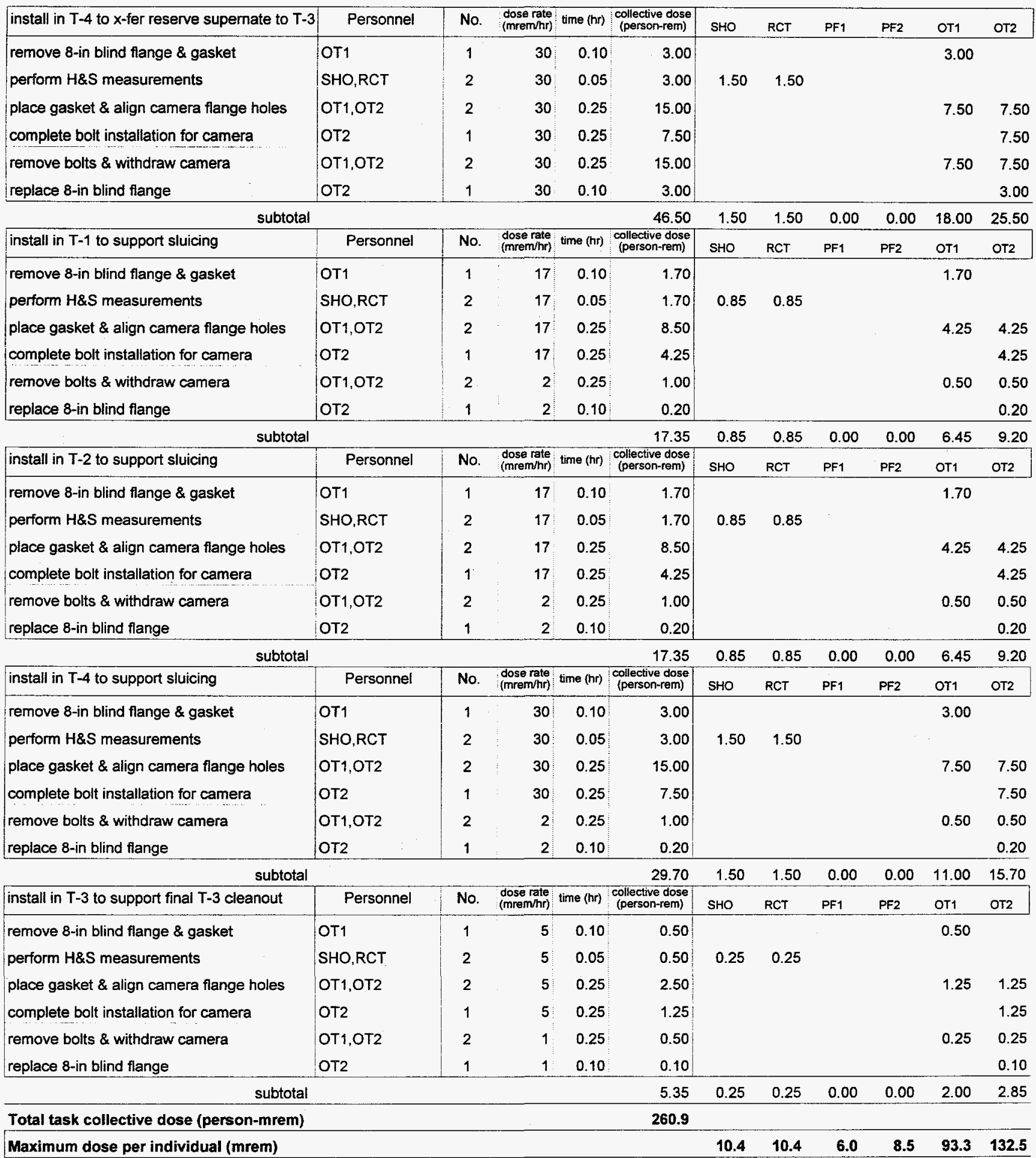




\section{Task B-5. Installing and Removing the Sluicer}

\section{Task Description}

This task is part of the sluicing and pumping phase of field activity for the OHF tanks contents removal campaign. The center piece of the OHF tanks contents removal project is the Borehole Miner high pressure sluicer. The components of the sluicer include support platform, moveable mast, and extendable/retractable arm which supports the spray nozzle. The support platform is a four-legged structure that supports the mast and distributes the weight between four adjustable legs. The mast is approximately $29 \mathrm{ft}$ long, made up of two sections of 5 -in. by 10 -in. rectangular tubing bolted together. The high pressure sluicing hose, hydraulic control lines, and extendable/retractable arm are located inside the mast. The mast is designed with an upper and lower bellows that allow extension and contraction of the mast length while encapsulating the mast components exposed to the tank contents. The lower bellows is attached to the riser flange during sluicing operations. Work Instruction 12, "Sluicer Mast Placement" (ORNL/ER-433, Energy Systems 1998), provides a detailed description of this task.

The key steps for installing the sluicer are as follows:

- Prepare area for sluicer stand placement-The immediate vicinity around the center riser will be prepared for the sluicer stand placement. Gravel may be spread to provide a level surface and four steel footer plates will be placed. The plates will be precisely aligned with the riser to ensure that placing the stand and sluicer can be accomplished as easily as possible.

- Remove bolts and bag flange cover-The center riser flange cover will be removed using an impact wrench. It is necessary for the tank ventilation system to be operational to ensure negative pressure while the tank is open to the atmosphere. All bolts will be removed except for one bolt, so that the lid can be rotated away from the riser opening and bagged. Once removed, the lid will be double-bagged and stored onsite. The bolts will also be double-bagged for disposal or reuse, depending on the condition.

- Align sluicer at riser opening and place legs-Three operations technicians and one rigger (acting as the designated flagman) will be involved in placing the sluicer. As the crane lowers the sluicer over the open riser, the crew will position each leg over the target points on the footer plates. Once the legs are positioned, the crane will lower the sluicer so that the weight of the stand rests on the legs and the active load is limited to the sluicer column itself. The stand will be leveled by adjusting the leg heights with an impact wrench.

- Remove drip pan and attach spray ring to flange- Once the stand is positioned and leveled, the drip pan will be unclamped from the spray ring. Two technicians will then lift the spray ring a few inches above the pan using two opposing lines while another technician removes the pan that is resting on the riser flange. The pan will contain a plastic bag with absorbent material that will be disposed. The pan will be double-bagged for reuse. Once the pan is removed, the spray ring is clamped and secured to the riser flange. At this point, the sluicer mast is lowered and locked into the final position. 
- Reconnect lines, hoses, and cables-Several lines, hoses, and cables, etc., will be connected with quick-connect attachments. It may be necessary to use a ladder to reach some of the connections.

- Remove crane tackle-The rigger will use a ladder to remove the crane tackle connected to a cable attached to the top of the sluicer mast. (This step may be omitted if the crane remains attached to the sluicer during sluicing and pumping operations.)

The key steps for removing the sluicer are as follows:

- Attach crane tackle-The rigger will use a ladder to attach the crane tackle to a cable attached to the top of the sluicer mast. (This step may be omitted if the crane remains attached to the sluicer during sluicing and pumping operations.)

- Disconnect and secure lines, hoses, and cables-Several lines, hoses, and cables, etc., will be disconnected with quick-disconnect attachments. It may be necessary to use a ladder to reach some of the connections. The cables, etc., will be bundled together and secured to prevent snagging during sluicer hoisting.

- Raise sluicer stand to maximum height-The four legs on the sluicer stand will be raised to their full upright position by using an impact wrench.

- Disconnect spray ring and attach drip pan-Once the spray ring is unclamped from the riser flange, two technicians will lift the spray ring a few inches above the riser opening by using two opposing lines while another technician places a drip pan on the riser flange. The pan will contain a disposable plastic bag with absorbent material. Once the spray ring is lowered onto the pan, it is clamped and secured to the drip pan.

- Re-install center riser flange cover-The center riser cover is replaced when the load is moved away from the riser vicinity. The original center riser cover may be replaced or a new cover may be used. The original gasket may also be reused, depending on the condition. An old gasket will be bagged and disposed. The effectiveness of the ventilation system should allow more than one tank riser to be open at a time (i.e., the next tank to be sluiced in addition to this opening) while still maintaining negative pressure. However, the riser opening should at least be "hot-bolted" closed as soon as possible after the sluicer mast is removed.

\section{Dose Estimates}

\begin{tabular}{|lc|}
\hline \multicolumn{1}{|c|}{ Position } & $\begin{array}{c}\text { Whole body dose } \\
\text { (mrem) }\end{array}$ \\
\hline Pipe Fitter \#1 (PF1) & 7.2 \\
Pipe Fitter \#2 (PF2) & 7.2 \\
Operations Technician \#1 (OT1) & 13.8 \\
Operations Technician \#2 (OT2) & 13.0 \\
\hline
\end{tabular}


Task B-5, Installing and Removing the Sluicer

\begin{tabular}{|lc|}
\hline \multicolumn{1}{|c|}{ Position } & $\begin{array}{c}\text { Whole body dose } \\
\text { (mrem) }\end{array}$ \\
\hline Operations Technician \#3 (OT3) & 3.6 \\
Crane Flagman (RG1) & 3.1 \\
SSHO (SHO) & 1.6 \\
Radiological Control Technician (RCT) & 1.6 \\
\hline Total & 51.0 \\
\hline
\end{tabular}

\section{Radiological Hold Points}

\section{Field Measurements}

- Preliminary dose rate measurements at the tank riser-Dose rate measurements will be made before opening a riser (i.e., loosening the bolts). If the dose rate is unexpectedly high (e.g., greater than $20 \%$ over the expected dose rate), further job planning is necessary before beginning work on the tank riser. For example, the ALARA dose estimates will be revised and precautionary steps may be added to reduce personnel exposure.

\section{Personnel Exposure}

Workers will use Siemens electronic pocket dosimeters with the alarm set point at 20 mrem cumulative dose and dose rate set point at approximately $20 \%$ over the maximum expected dose rate. Depending on the alarm, the RCT and SSHO will direct the worker to complete the specific step under way when the alarm sounds. If a worker's cumulative dose triggers an alarm, the RCT and SSHO will advise whether work assignments should be shifted between workers before proceeding.

\section{Walkdown or Dry Run}

The sluicer has been installed and operated at the cold test facility. Installation and withdrawal have been rehearsed and refined in noncontaminated environments. Work Instruction 12, "Sluicer Mast Placement," was developed using the cold test dry runs.

\section{Maximum Prefabrication}

No work beyond the basic installation or removal is necessary. The drip pan will be configured with its disposal bag and absorbent material before it is used in the radiological area.

\section{Staging Necessary Materials and Tools} hand.

Staging of materials and tools will be outside the radiological area. Duplicate tools will be on 
Task B-5, Installing and Removing the Sluicer

\section{Radioactive Material Reduction}

Waste materials from the job (e.g., gaskets, plastic, PPE, etc.) will be bagged and disposed. Recyclable items, such as overboots, will be segregated at the step-off pad for survey. No unnecessary items will be introduced into the radiological area.

\section{Engineered Controls}

Plastic will be used around each opening to minimize the potential for spreading contamination. The ventilation system will be operational to ensure negative pressure at the riser opening.

\section{Special Tooling or Work Processes}

A specialized drip pan with absorbent material will be used during sluicer transfer. It may also be necessary to use a pattern to help lay out the placement of the sluicer stand footer plates.

\section{Training}

Workers are required to complete Radiological Worker II training and be respirator qualified. Operations technicians must also be trained on Work Instruction 12, "Sluicer Mast Placement."

\section{Temporary Shielding}

No temporary shielding will be used.

\section{Emergency Procedures and Contingency Plans}

The work will be performed under the guidelines in the Site-Specific HASP for the OHF Tanks Contents Removal Project (ORNL/ER-427, Energy Systems 1997c). If an ORNL emergency alarm sounds, the SSHO will ensure that work stops immediately and that all workers are aware of the alarm and are taking the appropriate action. The Field Operations Superintendent will ensure that all equipment is secure and shutdown in a safe state. Chapter 7 of the Site-Specific HASP discusses evacuation plans and routes in more detail.

- Wind and inclement weather-Wind gusts must not exceed $15 \mathrm{mph}$. The SSHO will monitor the wind conditions and periodically contact the LSS for weather updates. The SSHO or RCT will terminate the job if conditions deteriorate in a way that prevents safe work or proper deactivation of the worksite. 
Installing and removing the sluicer

\begin{tabular}{|c|c|c|c|c|c|c|c|c|c|c|c|c|c|}
\hline Tank T-3 & Personnel & No. & $\begin{array}{l}\text { dose rate } \\
\text { (mrem/hr) }\end{array}$ & time (hr) & $\begin{array}{l}\text { collective dose } \\
\text { (person-mrem) }\end{array}$ & SHO & $\mathbf{R C T}$ & PF1 & PF2 & OT1 & OT2 & отЗ & RG1 \\
\hline prepare area for sluicer stand placement & PF1,PF2 & 2 & 1 & 0.25 & 0.50 & & & 0.25 & 0.25 & & & & \\
\hline remove botts \& bag T-3 flange cover & PF1,PF2 & 2 & 21 & 0.25 & 10.50 & & & 5.25 & 5.25 & & & & \\
\hline perform H\&S measurements @ T-3 & SHO,RCT & 2 & 21 & 0.05 & 2.10 & 1.05 & 1.05 & & & & & & \\
\hline align sluicer and position legs & PF1,PF2,OT1,RG1 & 4 & 2 & 0.20 & 1.60 & & & 0.40 & 0.40 & 0.40 & & & 0.40 \\
\hline remove drip pan, attach spray ring to flange & PF1,PF2,OT1 & 3 & 11 & 0.10 & 3.30 & & & 1.10 & 1.10 & 1.10 & & & \\
\hline reconnect lines, hoses, \& cables & PF1,PF2 & 2 & 2 & 0.10 & 0.40 & & & 0.20 & 0.20 & & & & \\
\hline remove crane tackle & RG1 & 1 & 2 & 0.10 & 0.20 & & & & & & & & 0.20 \\
\hline attach crane tackie & RG1 & 1 & 2 & 0.10 & 0.20 & & & & & & & & 0.20 \\
\hline disconnect \& secure lines, hoses, \& cables & OT1,OT2 & 2 & 2 & 0.10 & 0.40 & & & & & 0.20 & 0.20 & & \\
\hline raise sluicer stand to max height & OT1 & 1 & 1 & 0.25 & 0.25 & & & & & 0.25 & & & \\
\hline attach drip pan to spray ring & OT1, OT2, OT3 & 3 & 2 & 0.10 & 0.60 & & & & & 0.20 & 0.20 & 0.20 & \\
\hline re-install T-3 center flange cover & OT1,OT2 & 2 & 2 & 0.25 & 1.00 & & & & & 0.50 & 0.50 & & \\
\hline subtotal & & & & & 21.05 & 1.05 & 1.05 & 7.20 & 7.20 & 2.65 & 0.90 & 0.20 & 0.80 \\
\hline Tank T-1 & Personnel & No. & $\begin{array}{l}\text { dose rate } \\
\text { (mremunt) }\end{array}$ & time (nn) & $\begin{array}{c}\text { collective dose } \\
\text { (person-rem) }\end{array}$ & SHO & $\mathrm{RCT}$ & PF1 & PF2 & OT1 & OT2 & ОТ3 & RS1 \\
\hline prepare area for sluicer stand placement & OT1,OT2 & 2 & 1 & 0.25 & 0.50 & & & & & 0.25 & 0.25 & & \\
\hline remove bolts \& bag $T-1$ flange cover & OT1, OT2 & 2 & 2 & 0.25 & 1.00 & & & & & 0.50 & 0.50 & & \\
\hline perform H\&S measurements @ T-1 & SHO,RCT & 2 & 2 & 0.05 & 0.20 & 0.10 & 0.10 & & & & & & \\
\hline align stuicer @ $T-1$ and position legs & OT1, OT2, OT3,RG1 & 4 & 1 & 0.20 & 0.80 & & & & & 0.20 & 0.20 & 0.20 & 0.20 \\
\hline remove drip pan, attach spray ring to flange & OT1, ОТ2, ОT3 & 3 & 2 & 0.10 & 0.60 & & & & & 0.20 & 0.20 & 0.20 & \\
\hline reconnect lines, hoses, \& cables & OT1,0T2 & 2 & 1.5 & 0.10 & 0.30 & & & & & 0.15 & 0.15 & & \\
\hline remove crane tackle & RG1 & 1 & 1.5 & 0.10 & 0.15 & & & & & & & & 0.15 \\
\hline attach crane tackle & RG1 & 1 & 1 & 0.10 & 0.10 & & & & & & & & 0.10 \\
\hline disconnect \& secure lines, hoses, \& cables & OT1, OT2 & 2 & 1 & 0.10 & 0.20 & & & & & 0.10 & 0.10 & & \\
\hline raise sluicer stand to max height & OT2 & 1 & 1 & 0.25 & 0.25 & & & & & & 0.25 & & \\
\hline attach drip pan to spray ring & OT1, OT2, OT3 & 3 & 2 & 0.10 & 0.60 & & & & & 0.20 & 0.20 & 0.20 & \\
\hline re-install T-1 center flange cover & OT1,OT2 & 2 & 2 & 0.25 & 1.00 & & & & & 0.50 & 0.50 & & \\
\hline subtotal & & & & & 5.70 & 0.10 & 0.10 & 0.00 & 0.00 & 2.10 & 2.35 & 0.60 & 0.45 \\
\hline Tank T-2 & Personnel & No. & $\begin{array}{l}\text { dose rate } \\
\text { (mrem/hr) }\end{array}$ & time $(\mathrm{hr})$ & $\begin{array}{c}\text { collective dose } \\
\text { (person-rem) }\end{array}$ & SHO & RCT & PF1 & PF2 & OT1 & OT2 & OT3 & RG1 \\
\hline prepare area for sluicer stand placement & OT1,OT2 & 2 & 1 & 0.25 & 0.50 & & & & & 0.25 & 0.25 & & \\
\hline remove bolts \& bag T-2 flange cover & OT1,OT2 & 2 & 4 & 0.25 & 2.00 & & & & & 1.00 & 1.00 & & \\
\hline perform H\&S measurements @ T-2 & SHO,RCT & 2 & 4 & 0.05 & 0.40 & 0.20 & 0.20 & & & & & & \\
\hline align sluicer @ T-2 and position legs & OT 1, OT 2, OT $3, R G 1$ & 4 & 1 & 0.20 & 0.80 & & & & & 0.20 & 0.20 & 0.20 & 0.20 \\
\hline remove drip pan, attach spray ring to flange & OT1, OT2, OT3 & 3 & 4 & 0.10 & 1.20 & & & & & 0.40 & 0.40 & 0.40 & \\
\hline reconnect lines, hoses, \& cables & OT1,OT2 & 2 & 3 & 0.10 & 0.60 & & & & & 0.30 & 0.30 & & \\
\hline remove crane tackle & RG1 & 1 & 3 & 0.10 & 0.30 & & & & & & & & 0.30 \\
\hline attach crane tackle & RG1 & 1 & 1 & 0.10 & 0.10 & & & & & & & & 0.10 \\
\hline disconnect \& secure lines, hoses, \& cables & OT1,OT2 & 2 & 1 & 0.10 & 0.20 & & & & & 0.10 & 0.10 & & \\
\hline raise sluicer stand to max height & OT2 & 1 & 1 & 0.25 & 0.25 & & & & & & 0.25 & & \\
\hline attach drip pan to spray ring & OT1, OT2, OT3 & 3 & 2 & 0.10 & 0.60 & & & & & 0.20 & 0.20 & 0.20 & \\
\hline re-install $T-2$ center flange cover & OT1, OT2 & 2 & 2 & 0.25 & 1.00 & & & & & 0.50 & 0.50 & & \\
\hline \multicolumn{5}{|l|}{ subtotal } & 7.95 & 0.20 & 0.20 & 0.00 & 0.00 & 2.95 & 3.20 & 0.80 & 0.60 \\
\hline
\end{tabular}


Installing and removing the sluicer (continued)

\begin{tabular}{|c|c|c|c|c|c|c|c|c|c|c|c|c|c|}
\hline Tank T-4 & Personnel & No. & $\begin{array}{l}\text { dose rate: } \\
\text { (mrem/hr) }\end{array}$ & time (hi) & $\begin{array}{l}\text { collective dose } \\
\text { (person-rem) }\end{array}$ & SHO & RGT & PF1 & PF2 & OT1 & OT2 & OT3 & RG1 \\
\hline prepare area for sluicer stand placement & OT1,OT2 & 2 & 1 & 0.25 & 0.50 & & & & & 0.25 & 0.25 & & \\
\hline remove bolts \& bag T-4 flange cover & OT1,0T2 & 2 & 2 & 0.25 & 1.00 & & & & & 0.50 & 0.50 & & \\
\hline perform H\&S measurements $@ T-4$ & SHO,RCT & 2 & 2 & 0.05 & 0.20 & 0.10 & 0.10 & & & & & & \\
\hline remove drip pan, attach spray ring to flange & OT1, OT2,0T3 & 3 & 10 & 0.10 & 3.00 & & & & & 1.00 & 1.00 & 1.00 & \\
\hline reconnect lines, hoses, \& cables & OT1, OT2 & 2 & 6 & 0.10 & 1.20 & & & & & 0.60 & 0.60 & & \\
\hline remove crane tackle & RG1 & 1 & 6 & 0.10 & 0.60 & & & & & & & & 0.60 \\
\hline attach crane tackle & RG1 & 1 & 1 & 0.10 & 0.10 & & & & & & & & 0.10 \\
\hline disconnect \& secure lines, hoses, \& cables & OT1,OT2 & 2 & 1 & 0.10 & 0.20 & & & & & 0.10 & 0.10 & & \\
\hline raise sluicer stand to max height & OT2 & 1 & 1 & 0.25 & 0.25 & & & & & & 0.25 & & \\
\hline attach drip pan to spray ring & OT1, OT2,OT3 & 3 & 2 & 0.10 & 0.60 & & & & & 0.20 & 0.20 & 0.20 & \\
\hline re-install T-4 center flange cover & OT1,OT2 & 2 & 2 & 0.25 & 1.00 & & & & & 0.50 & 0.50 & & \\
\hline subtotal & & & & & 8.65 & 0.10 & 0.10 & 0.00 & 0.00 & 3.15 & 3.40 & 1.20 & 0.70 \\
\hline Tank T-9 & Personnel & No. & $\begin{array}{l}\text { cose rate } \\
\text { (mrem/hr) }\end{array}$ & time (hr) & $\begin{array}{l}\text { collective dose } \\
\text { (person-rem) }\end{array}$ & SHO & RCT & $\mathrm{PF} 1$ & PF2 & OT1 & OT2 & OT3 & RG1 \\
\hline prepare area for sluicer stand placement & OT1, OT2 & 2 & 1 & 0.25 & 0.50 & & & & & 0.25 & 0.25 & & \\
\hline remove mixer & От1, от2 & 2 & 2 & 0.50 & 2.00 & & & & & 1.00 & 1.00 & & \\
\hline perform H\&S measurements @ T-9 & SHO,RCT & 2 & 2 & 0.05 & 0.20 & 0.10 & 0.10 & & & & & & \\
\hline align sluicer @ T-9 and position legs & OT1,OT2,OT3,RG1 & 4 & $1:$ & 0.20 & 0.80 & & & & & 0.20 & 0.20 & 0.20 & 0.20 \\
\hline remove drip pan, attach spray ring to flange & OT1, OT2, OT3 & 3 & 4 & 0.10 & 1.20 & & & & & 0.40 & 0.40 & 0.40 & \\
\hline reconnect lines, hoses, \& cables & OT1, OT2 & 2 & 2.5 & 0.10 & 0.50 & & & & & 0.25 & 0.25 & & \\
\hline remove crane tackle & RG1 & 1 & 2.5 & 0.10 & 0.25 & & & & & & & & 0.25 \\
\hline attach crane tackle & RG1 & 1 & 1 & 0.10 & 0.10 & & & & & & & & 0.10 \\
\hline disconnect $\&$ secure lines, hoses, \& cables & OT1,OT2 & 2 & 1 & 0.10 & 0.20 & & & & & 0.10 & 0.10 & & \\
\hline raise sluicer stand to max height & от2 & 1 & 1 & 0.25 & 0.25 & & & & & & 0.25 & & \\
\hline attach drip pan to spray ring & OT1,OT2,OT3 & 3 & 2 & 0.10 & 0.60 & & & & & 0.20 & 0.20 & 0.20 & \\
\hline re-install T-9 flange cover & OT1, OT2 & 2 & 2 & 0.25 & 1.00 & & & & & 0.50 & 0.50 & & \\
\hline \multicolumn{5}{|l|}{ subtotal } & 7.60 & 0.10 & 0.10 & 0.00 & 0.00 & 2.90 & 3.15 & 0.80 & 0.55 \\
\hline \multicolumn{5}{|l|}{ Total task collective dose (person-mrem) } & 51.0 & & & & & & & & \\
\hline \multicolumn{6}{|l|}{ Maximum dose per individual (mrem) } & 1.6 & 1.6 & 7.2 & 7.2 & 13.8 & 13.0 & 3.6 & 3.1 \\
\hline
\end{tabular}

Page 27 
Appendix C

\section{DAILY ALARA PRE-JOB BRIEFING TOPICS}


NOTE: All items may not be applicable each day.

a. The scope of work to be performed. This includes instruction on what kinds of actions or work would exceed the scope of the RWP.

b. Radiological conditions in the workplace.

c. Procedural and RWP requirements.

d. Special radiological control requirements. For example, the use of extremity or supplemental dosimetry, special dosimeter locations, and why these special locations were chosen.

e. Radiologically limiting conditions, such as radiation or contamination levels greater than expected.

f. Radiological control hold points.

g. Communications and coordination with other groups.

h. Emergency and alarm response instructions.

i. A brief discussion of what actions or anticipated potential problems might decrease shielding, increase work time, or decrease the effective distance from the source.

j. How to respond to a failure of PPE and instructions for workers and observers to periodically check each other's PPE for failures.

k. What to do if alarms sound.

1. What to do if job plans do not match the actual situation encountered, for example, scope or execution of task or much higher than expected radiation levels.

m. Verification that all needed tools, parts, materials, and instructions needed to perform the work are present and in usable condition.

$\mathrm{n}$. What to do if containment or ventilation fails.

o. Controls and instructions related to the use of temporary shielding, if used. 


\section{Appendix D}

\section{ALARA OPERATIONS REVIEW CHECKLIST}


1. For each phase of the operation, have the following been done:

a. Has a process been established that includes appropriate radiological steps or considerations?

b. Have the number of workers, their positions, their movements, and their stay times been estimated for each phase?

c. Have estimates based on measured or calculated dose rates been determined for each position above for (1) whole body, (2) extremities, (3) skin, and (4) other, as applicable?

2. Have dose estimates been made for the following?

a. Each worker (or a typical worker) in each phase?

b. Collectively for each phase?

c. ALARA goals (totals or for each phase)?

3. Have the following been considered or planned?

a. Lowering radiation or airborne radioactivity levels by:

1. Shielding

2. Draining, flushing, or purging of components

3. Decontaminating components, areas, etc.

4. Using local or "spot" exhaust ventilation

b. Minimizing time spent in Radiological Areas by:

1. Using special or remotely operated tools

2. Using experienced workers

3. Providing special or additional training for workers

4. Using mockups and dry-runs

5. Planning access paths, means of transport of heavy equipment, etc.

6. Having a pre-job briefing

7. Removing physical interferences and blockages from area

8. Having appropriate portions of the work performed out of radiological areas

9. Listing and collecting all tools, parts, spares, etc., ahead of time

10. Providing adequate laydown space

11. Providing service lines to area (power, air, etc.)

12. Identifying and establishing low dose areas 
Appendix D (continued)

c. Accommodating human factors by:

1. Providing extra lighting

2. Providing scaffolding, ladders, and supports as needed

3. Providing adequate ventilation

4. Providing adequate communication methods (with backups if in dangerous or high radiation areas)

d. Controlling the potential spread of contamination by:

1. Decontaminating components, areas, etc.

2. Covering or spraying contaminated surfaces to reduce airbornes

3. Covering or coating clean surfaces for ready decontamination

4. Providing containment or enclosure (tent, glove box, receiving bags for contaminated items, and the like)

5. Providing means of collecting drainage, loose particles, and other escaping material (in pans, with vacuum suctioners or cleaners, etc.)

6. Providing local ventilation

7. Filtering exhaust air

e. Controlling access by:

1. Providing adequate procedures, checks, and Radiological Control Technician (RCT) coverage for entries into appropriate Radiological Areas

2. Having area prominently posted by the RCT before the operation

f. Minimizing impact on other areas, systems, and operations by:

1. Weighing effects of increased dose rate on adjacent areas

2. Ensuring that wind does not transport airbornes out of the subject area

3. Isolating the subject system from other systems and from other uninvolved components in the same system, as appropriate

4. Coordinating the subject operation with other operations

5. Ensuring that any new installation or operation does not adversely affect future use of other systems (their operation, maintenance, inspection, calibration, etc.)

g. Ensuring safety by:

1. Providing adequate administrative controls and safeguards when disabling or bypassing safety systems and components (e.g., overriding interlocks) 


\section{Planning (Preoperational Review)}

2. Making sure contingency plans exist if rescue may become necessary

3. Reviewing applicable abnormal and emergency procedures and plans

4. Reviewing to determine if added shielding will produce any problems such as excessive weight or unstable configurations

5. Making sure that radiological safety measures will not contribute to other safety problems such as heat stress and fire safety problems

6. Reviewing if work might involve criticality issues

4. Have radiological controls been planned:

a. Radiological Work Permit (RWP) reviewed and approved?

b. Posting

c. Radiation protection coverage

d. Radiological hold points

e. Formal ALARA engineering review

f. Other

5. Have the following been provided for the making of the operational record, as appropriate:
a. Photographs
b. Videotape
c. Other 
1. Are there any conditions which have changed or controls which have been added since the Planning section was completed? If so, describe below, including any changes in estimated doses or dose rates.

2. Have radiological controls been put into place [for references put name(s) and date of individual(s) confirming the item]

a. RWP reviewed and approved?

References:

b. Posting

References:

c. RCT coverage

References:

d. Hold points

References:

e. Other

References:

NOTE: Controls must be in place before the start of the operation. 
1. Has the operation been documented and the agreements and disagreements with the ALARA plan noted?

2. Have the results of dosimetry readings and air sampler results been compared to the anticipated values as given in the ALARA plan?

3. Have the collective doses for each stage and the entire operation been compared to the dose goals as given in the ALARA plan?

4. Has the effectiveness of dose reduction measures been evaluated?

5. Have notable occurrences, deviations from procedure or methods as described in the ALARA plan, and "lessons learned" been evaluated?

6. Have records been made of the operation as planned (photographs, videotapes, etc.)?

7. Has the documentation of the postoperation review been placed in the project file and sent to appropriate parties? 


\section{DISTRIBUTION}

1. C. A Bednarz

2. G. F. Boris

3. C. L. Callis

4. C. Clark, Jr.

5. J. E. Francis

6. D. L. Garrett

7. P. T. Owen

8. L. B. Raulston

9. D. G. Rowland

10. M. W. Stafford

11. R. F. Utrera

12. M. L. Whitehead

13. Central Research Library

14. File-EMEF DMC-RC 